العنف الجنسي ضد المحارم

"دراسة ميدانية على عينة من الضحايا 

العنف الجنسي ضد المحارم

دراسة ميدانية على عينة من الضحايا

سحر حساني، بسنت حمزة"

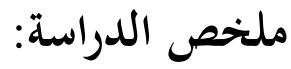

تهدف الدراسة إلى التعرف على طبيعة مشكلة العنف الجنسي الموجه للنساء، وأشكاله

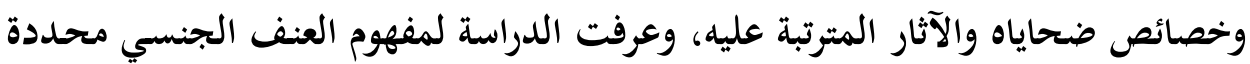

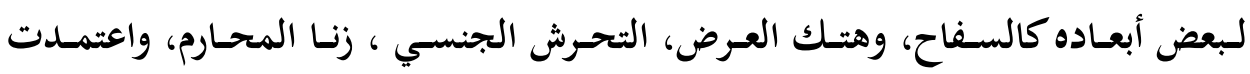

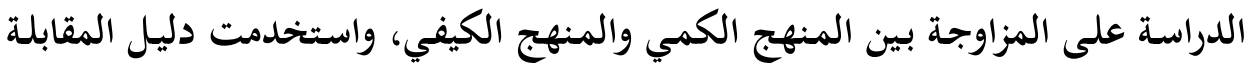

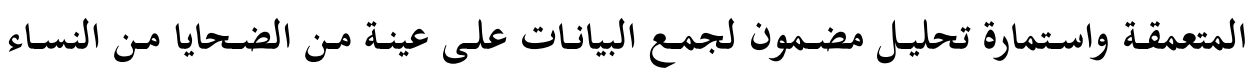

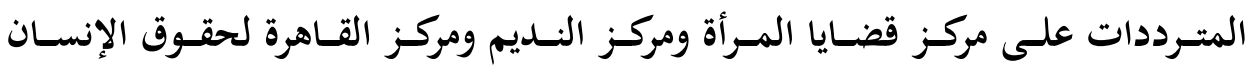

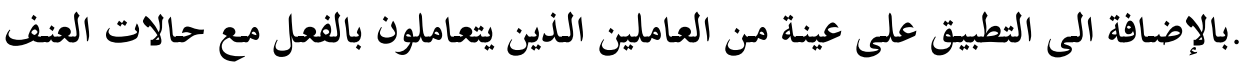

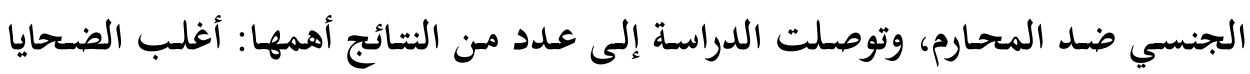

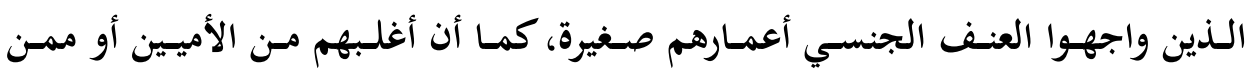

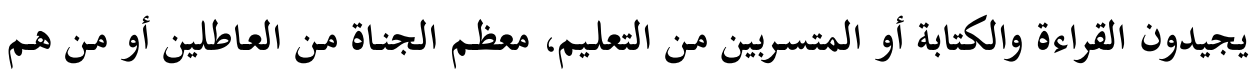
دون سن العمل أو على المعاش أو من العاملين فى مهن حرفية. كلمات مفتاحية: العنف الجنسي، زنا المحارم، التحرش الجنسي.

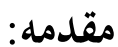

يرتبط الزواج القرابي بظاهرة تعرفها المجتمعات الإنسانية وهي ظـاهرة المحسارم

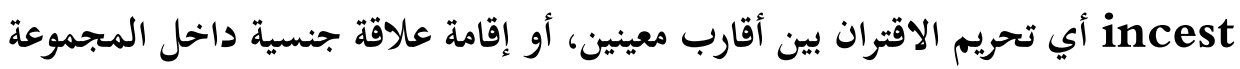

" " أ.د سحر حسانى بربري، أستاذ مساعد علم الاجتماع-كلية الآداب-جامعة قناة السويس. • بسنت خيرت حمزة، مدرس علم الاجتماع-كلية الآداب-جامعة قناة السويس. 
القرابية، ولا تسـتند هـذه الظـاهرة إلي الغريزة بقدر مـا تستـند إلي نظـام ثقافي يأخـذ بـه

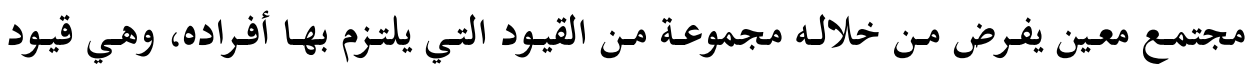
تختلف من مجتمع إلي آخر.

ولا شك في أن عملية التحديث التي يمر بها المجتمع تعمل علي ممارسة نوعاً من العنف علي البنية التقليدية للمجتمع ويحدث تحول تدريجي من مجتمع منغلق علي ذاته إلي مجتمع منفتح علي ما هو خحارجي وجديد، وينجم عن هذا التحول بعض التغيرات

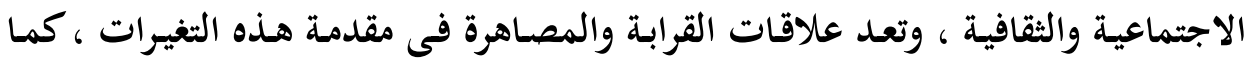
يتبع تلك التغيرات شروخ في البنية الثقافية للمجتمع مـع مـا يصـاحب ذلك من شعور بالفوضي واختلال المعايير. وهكذا نلاحظ أن التحديث والتحضر يؤديان إلي تعقد الحياة الاجتماعية وتشيوء العلاقات الإنسانية وبالتالي تزداد معدلات الجرائم الأسرية التي يكون

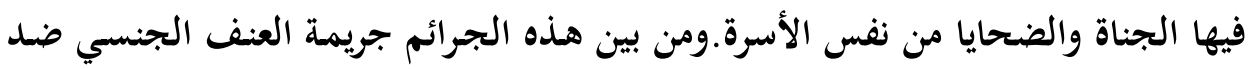

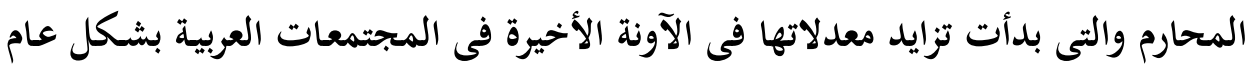
والمجتمع المصري على وجه الخصوص.لذلك تحاول هذه الدراسة التعرف على طبيعة

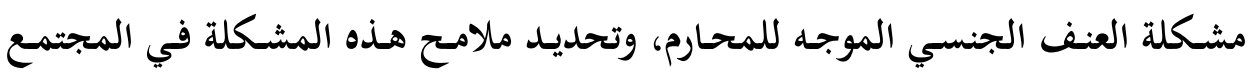
المصري والعوامل المتسببة فى حدوثها، من خلال تحليل مضمون حديث الضحايا الذين

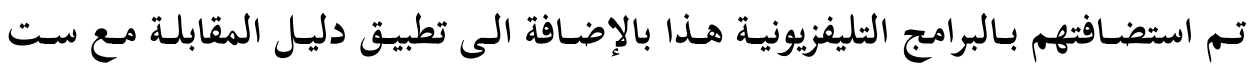
حالات من المترددات على مركز قضايا المرأة ومركز القاهرة للتنمية وحقوق الإنسان. وخلصت النتائج الى تعرض أغلبية الضحايا لأشكال متعددة من العنف فإلى جانب تعرضهم للعنف الجنسي تعرضوا أيضا للعنف الجسدى والنفسي والعاطفى .وتمثل العنف الجنسي الموجه للمحارم فى الاغتصاب، هتك العرض ، التحرش. أولاًَ- مشكلة الدراسة:

يـرتبط الزواج القرابـي بظـاهرة تعرفها المجتمعـات الإنسـانية وهـي ظـاهرة المحسارم incest 
القرابيـة، ولا تسـتند هـذه الظـاهرة إلي الغريزة بقـدر مـا تسـتند إلي نظـام ثقـافي يأخـــ بـه

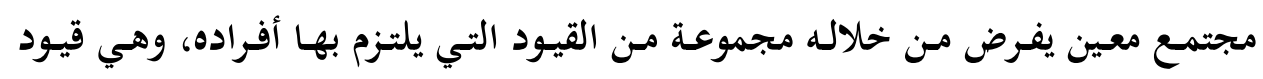
تختلف من مجتمع إلي آخر.

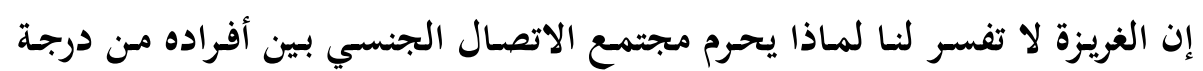

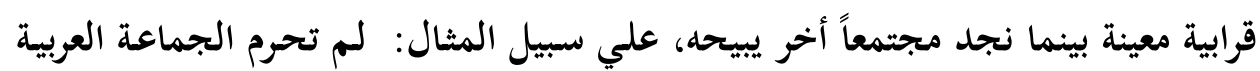

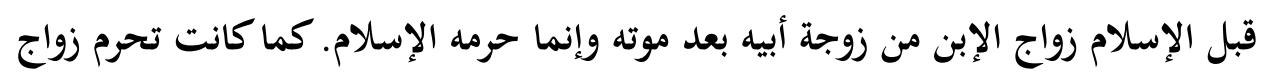

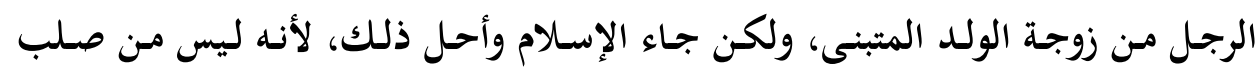

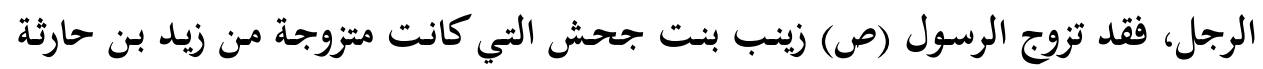

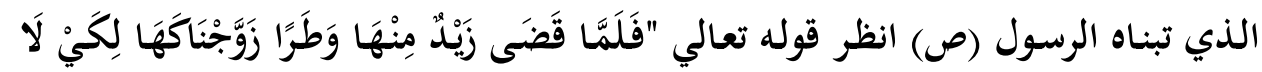

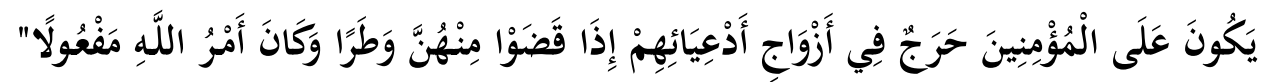

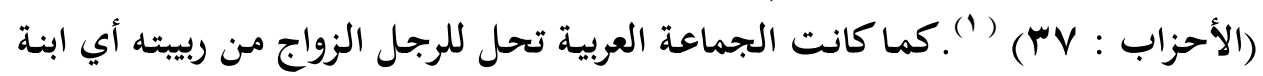

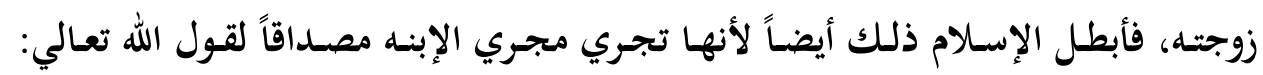

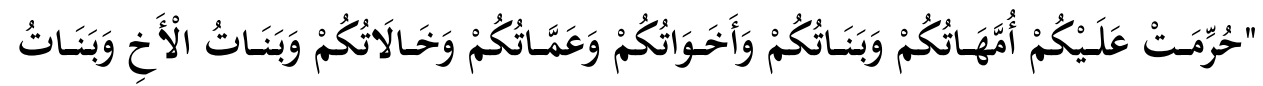

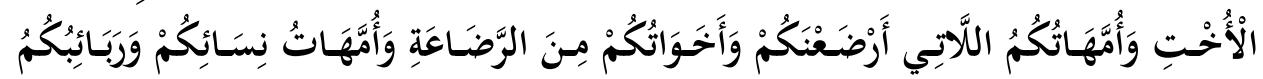

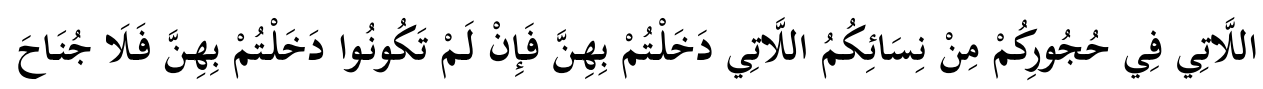

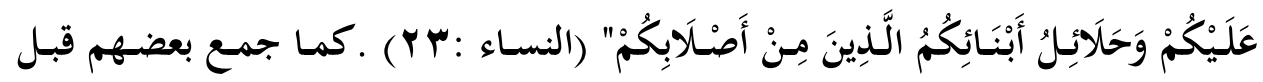

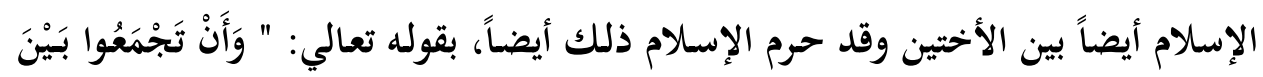

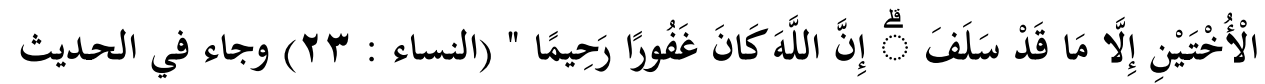

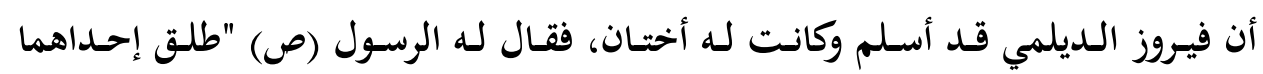
وإمسك الآخري". وهكذا حدد الإسلام النساء المحرمات اللاتى لا يجوز الاقتران بهن لأسباب ثلاثة هي: القرابة، والمصاهرة ، والرضاع. فالآية الكريمة حددت من يحرم الزواج

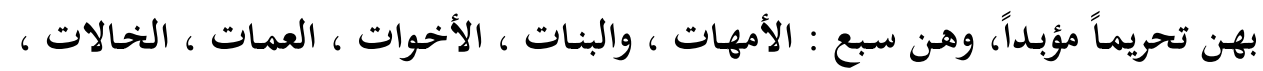

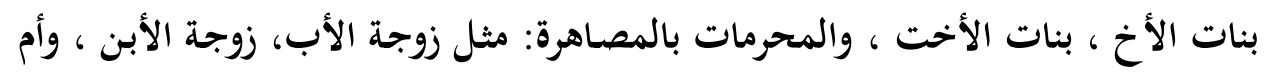


الزوجة، وأبنة الزوجة، والجمع بين الأختين.كما نصت الآية الكريمة علي أن الرضساع

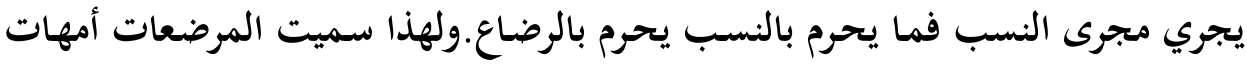

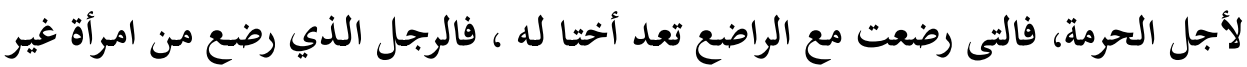

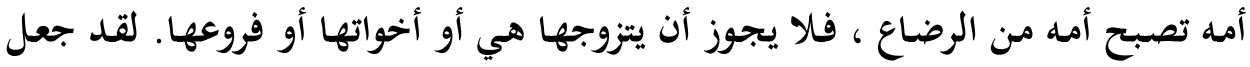

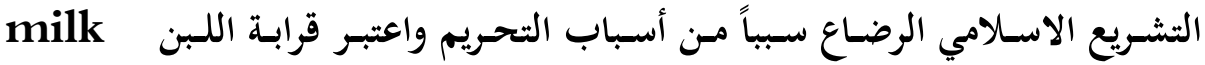

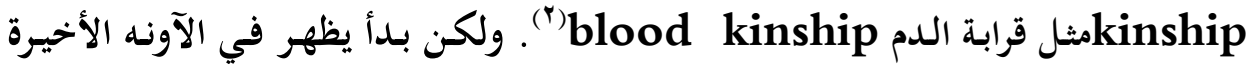

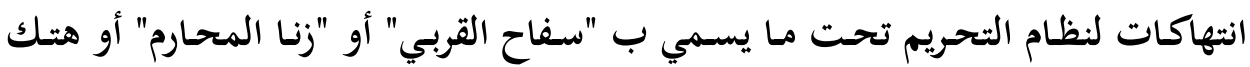

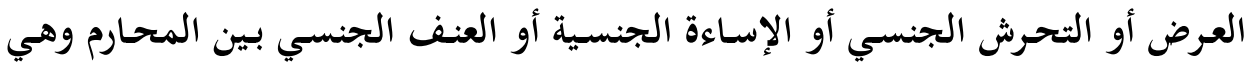

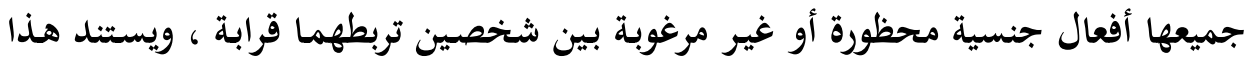
الحظر أو التحريم لمعايير ثقافية أو دينية. الأمر الذي يؤدي التئي إلي إهتزاز معاني الأبوة

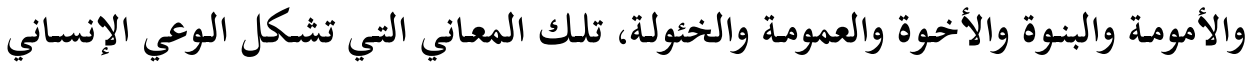

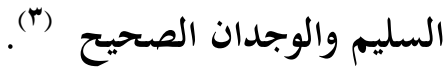
وعلي الرغم من أن الأسرة هي أول مجالات التفاعل اليومي وأكثرها ألفه للفرد، فهي

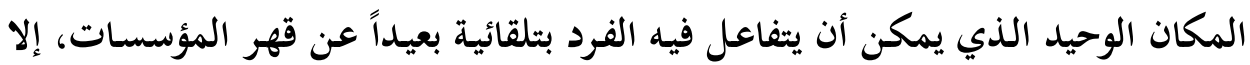

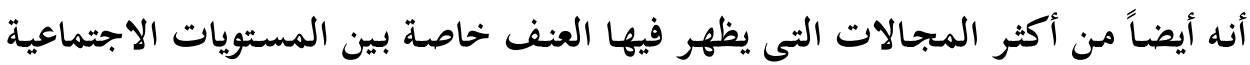

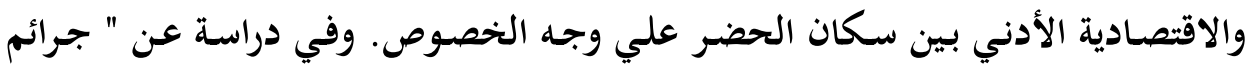

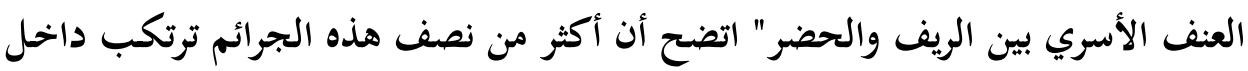

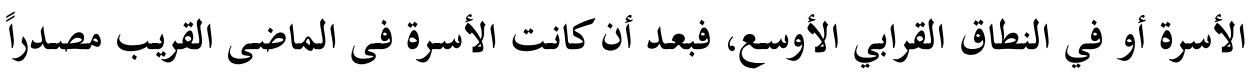

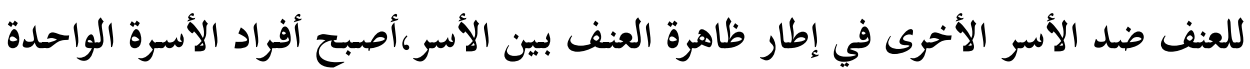

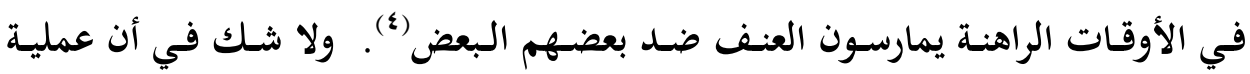
التحديث التي يمر بها المجتمع تعمل علي ممارسة نوع من العنف علي البنية التقليدية

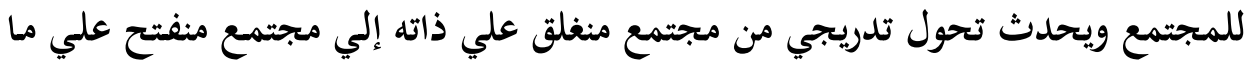
هو خارجي وجديد، وينجم عن هذا التحول بعض التغيرات الاجتماعية والثقافية، وتعد 
علاقات القرابة والمصاهرة فى مقدمة هذه التغيرات ، كما يتبع تلك التغيرات شروخ في

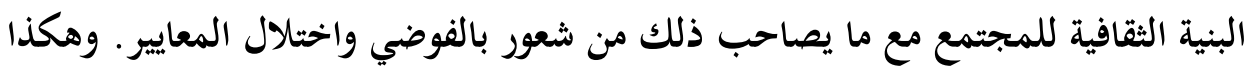

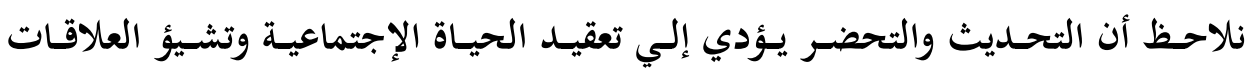

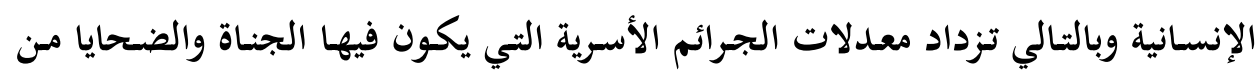
نفس الأسرة)(0) وأوضح دليل علي ذلك ما أشارت إليه الإحصاءات العالمية حول ارتفاع العنف الجنسي

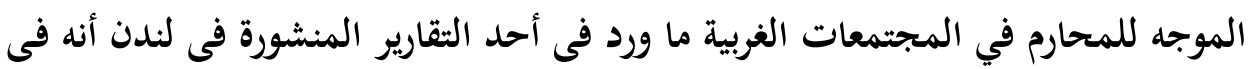

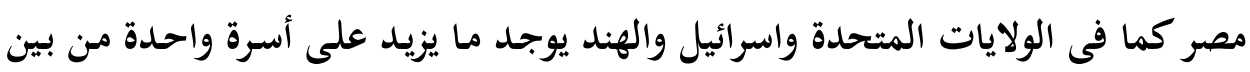

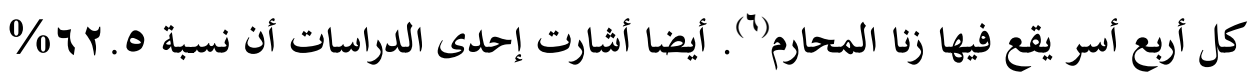

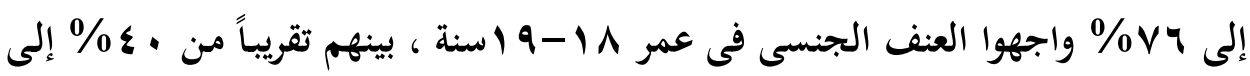

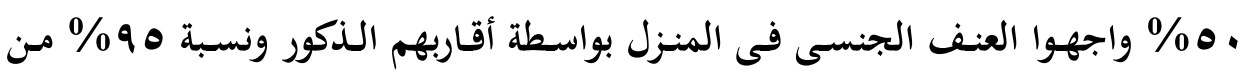

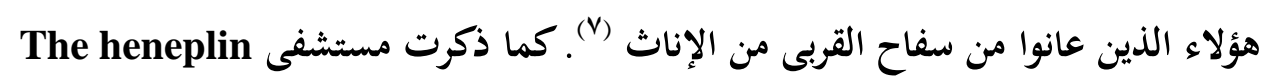
country medical center

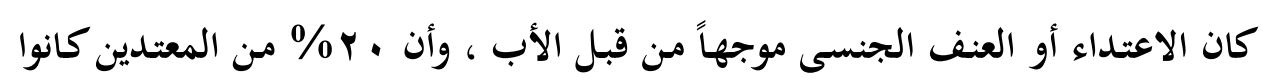

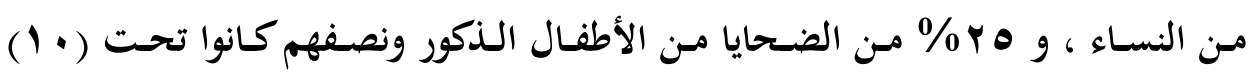

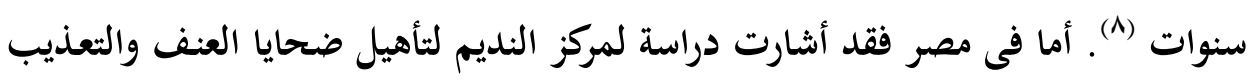

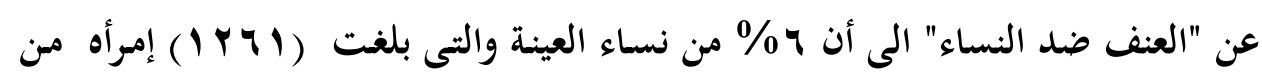

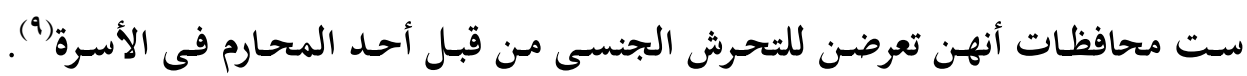

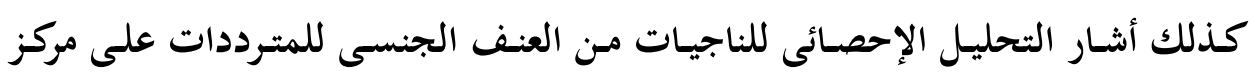

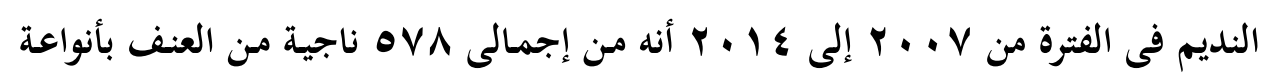

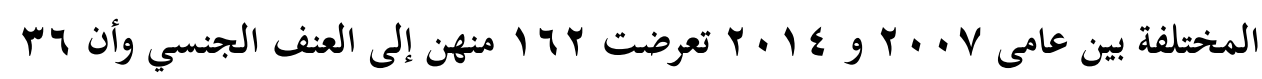

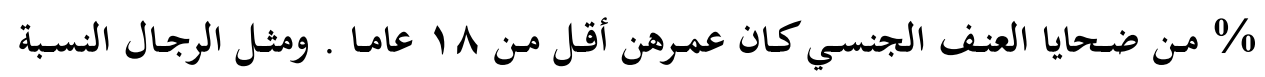

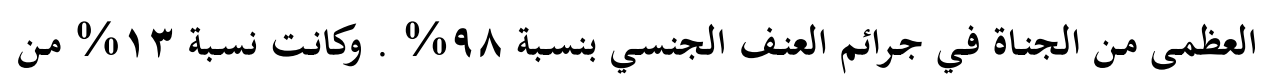


الناجيات كان الاعتداء من جانب أحد الأقارب (أقباء بالدم) (الأب في • 1 حالات -

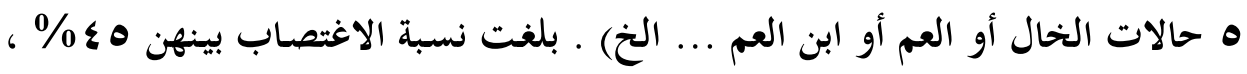

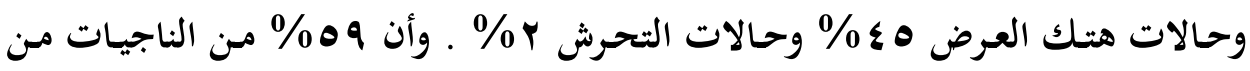

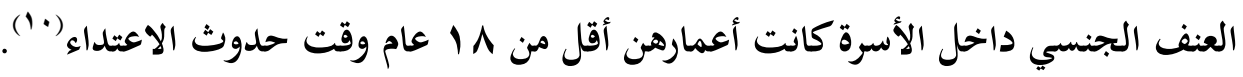

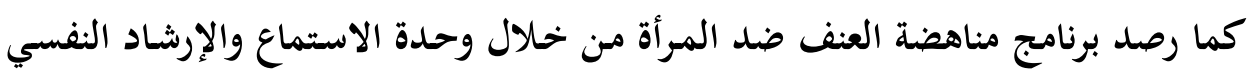

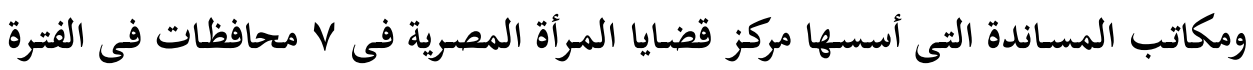

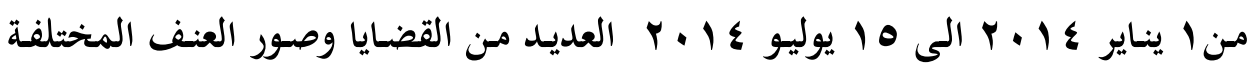

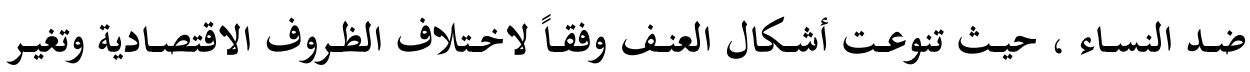
الأجواء السياسية التى مر بها المجتمع المصرى ، فقد رصدت الوحدة ومكاتب المساندة

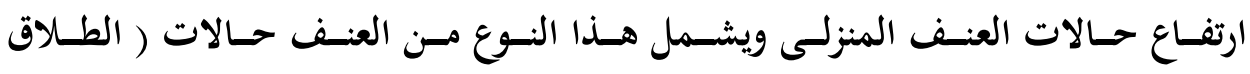

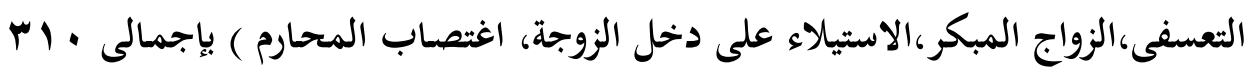

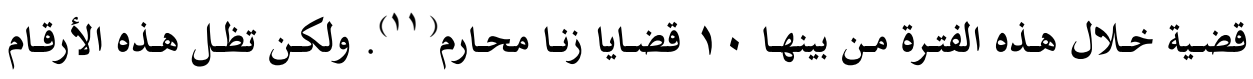

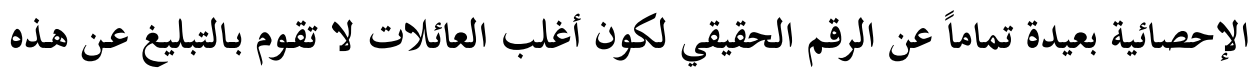

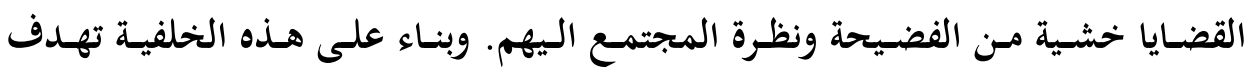

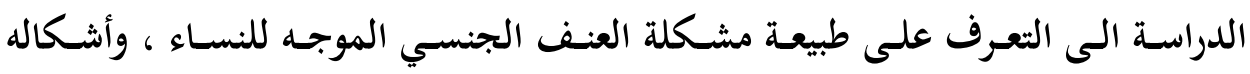
وخصائص ضحاياه والآثار المترتبة عليه ، فى محاولة للإجابة على الأسئلة التالية: 1- ما سمات وخصائص كل من الضحايا والجناة؟ Y- ما أشكال العنف الجنسي الموجهه للنساء في الأسرة ؟

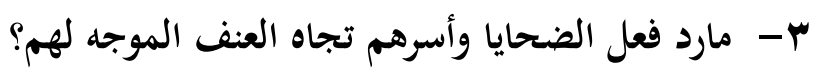

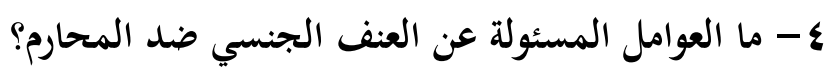

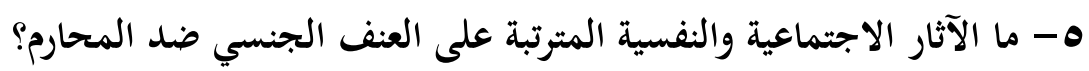

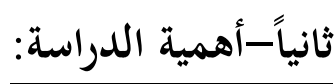


العنف الجنسي الموجه للمحارم يعد جريمة تقع في الممنوع الاجتماعي، خاصة إذا

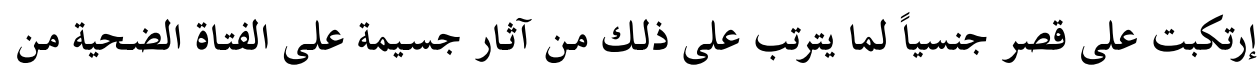

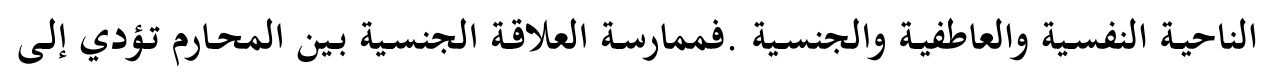

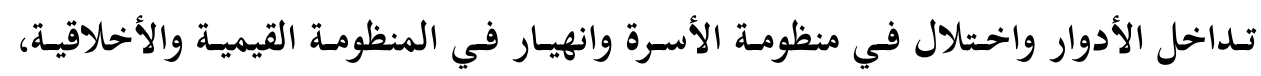

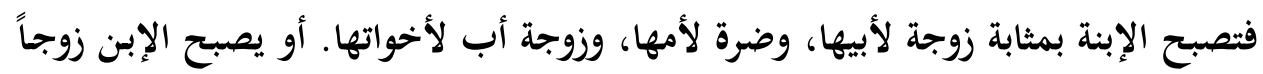

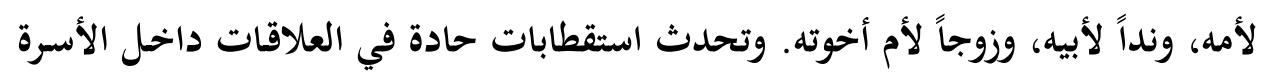

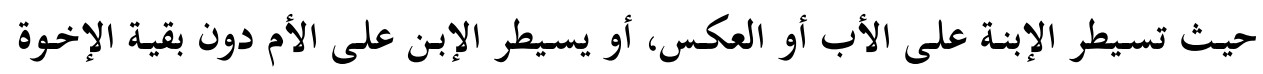

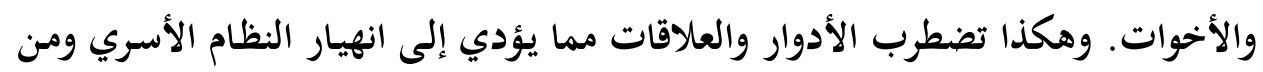

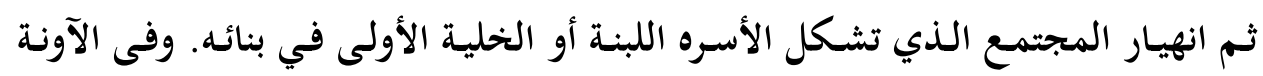

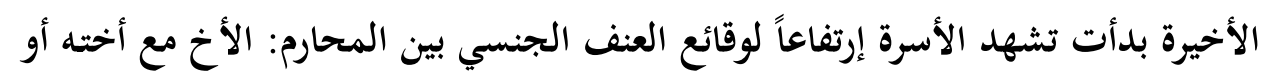

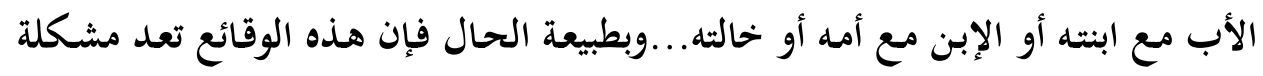

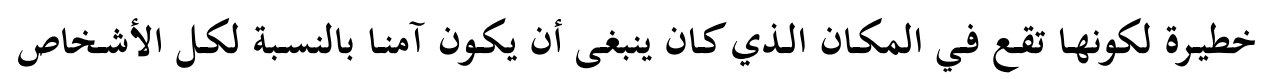

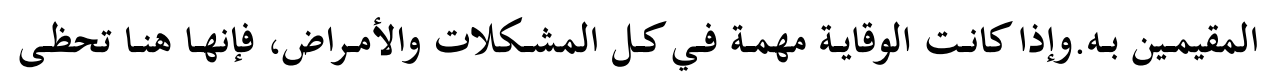

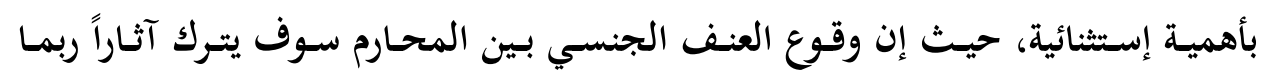

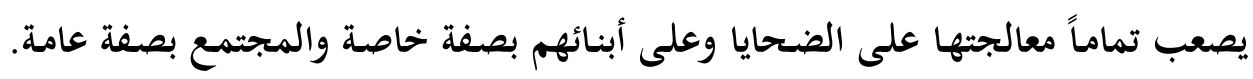
لذلك من الضروري وضع الوسائل الوقائية في الاعتبار. ثالثاً_مفاهيم الدراسة:

يعرف بأنه" ممارسة الجنس بغير تراضي أو رضا بـدءاً من استخدام التهديدات

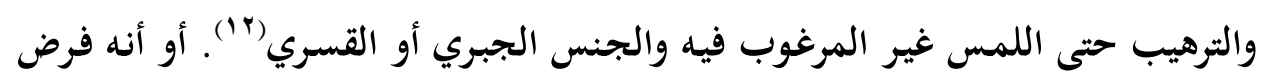

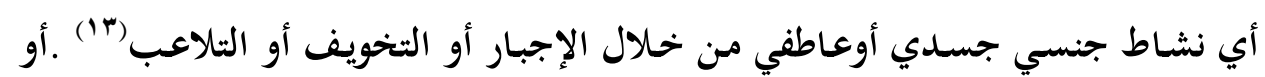

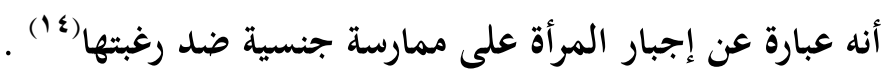


ويمكن تعريف العنف الجنسي إجرائياً باعتباره سلوكاً جنسياً غير مرغوب فيه موجهاً

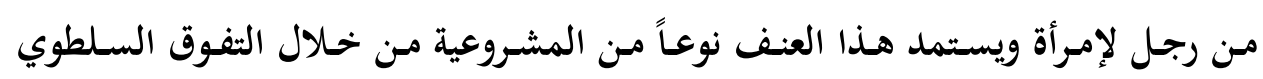

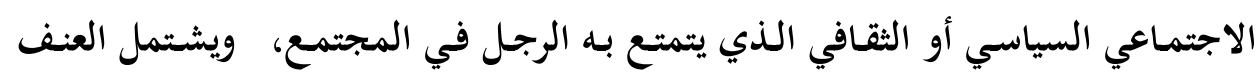

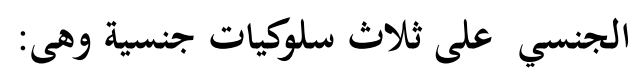

أ- السفاح: الجنسي على

سفاح القربى أو غشيان المحارم أو زنا المحارم هي مسميات لكلمة واحدة وهي

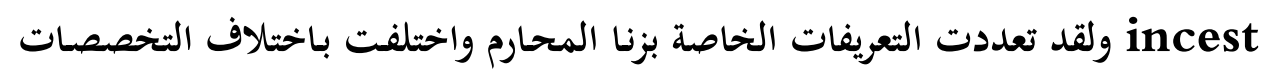

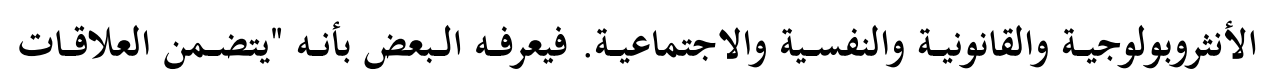

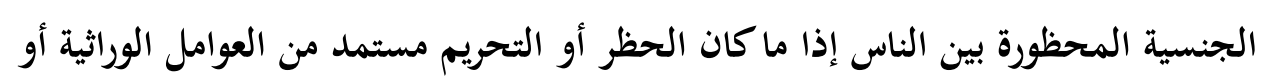

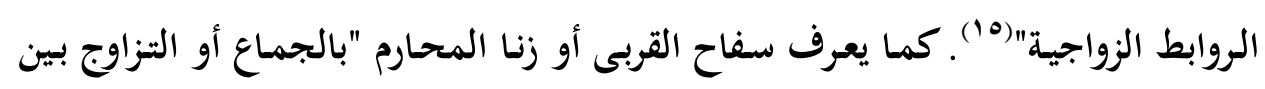

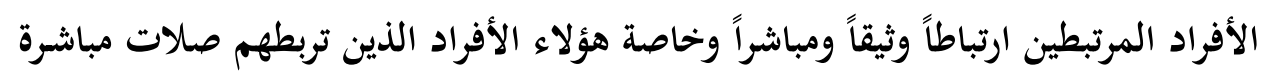

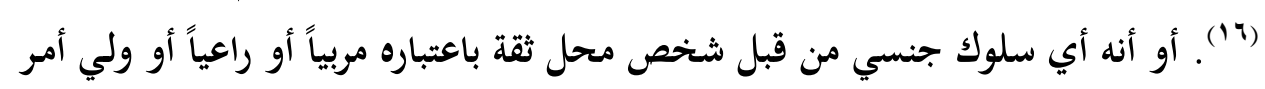
أو تربطه روابط دم بالشخص المعتدي عليه (IV) .

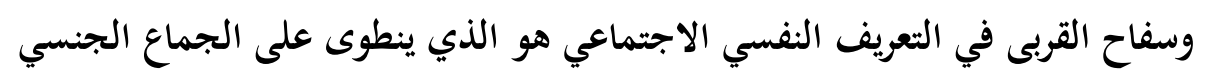

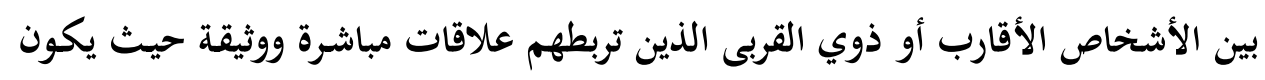

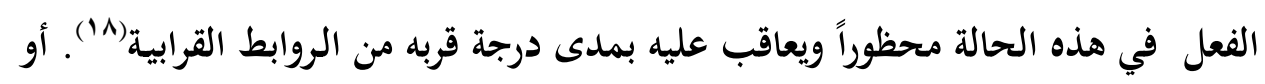

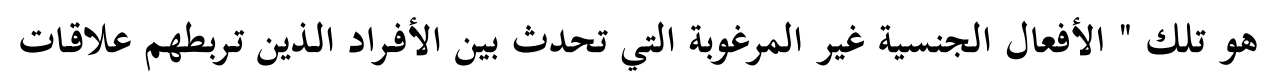

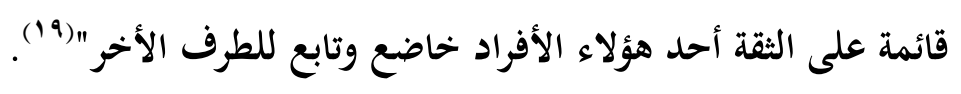
ب-هيتك العرض:

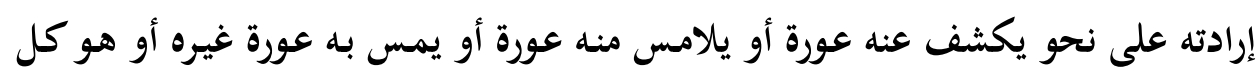

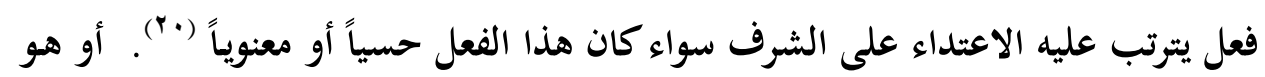

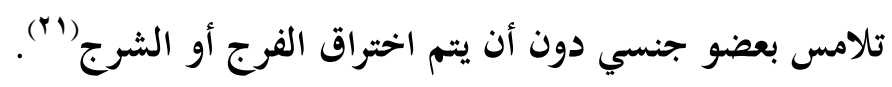


ج- التحرش الجنسي: التحرش الجنس ترجمة للتعبير الإنجليزي Sexual harassment والتحرش الترش الجنسي هو أي قول أو فعل يحمل دلالات جنسية تجاه شخص آخدر آئأذى من ذلك الإنك

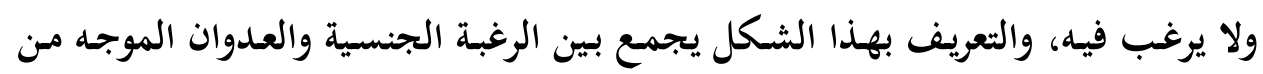

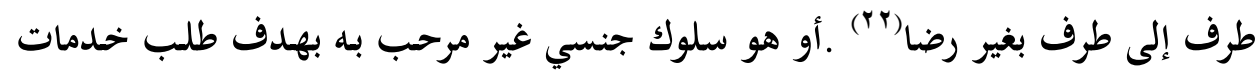

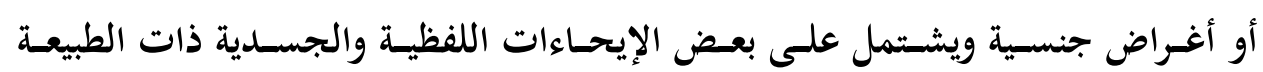
الجنسية، كذلك مقترحات جنسية غير مرغوب فيها، تعليق صسور جنسية حول جسسم الشخص، لمس غير مرغوب فيه، اختلاس النظر، النكات والتعليقات الجنسية (Tr).

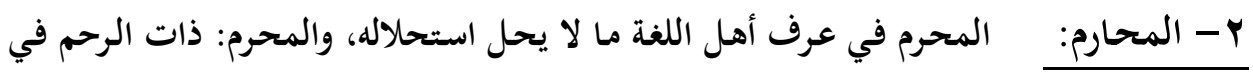

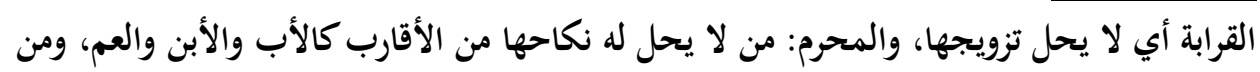

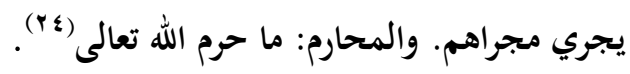

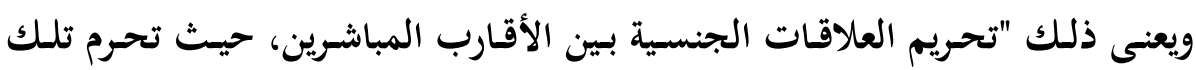

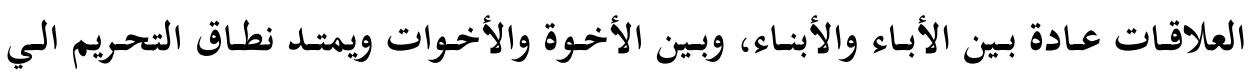

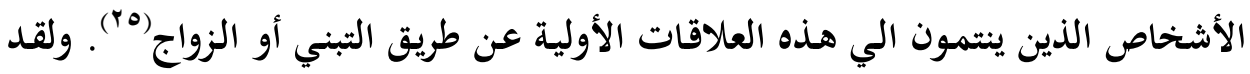

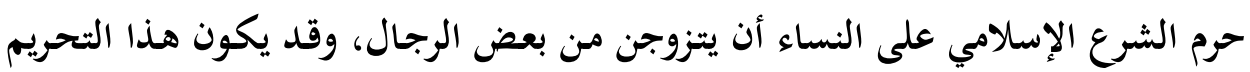

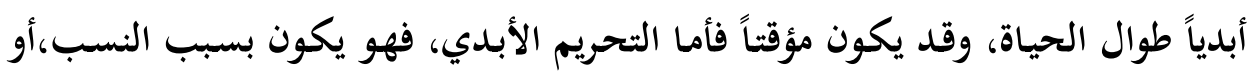

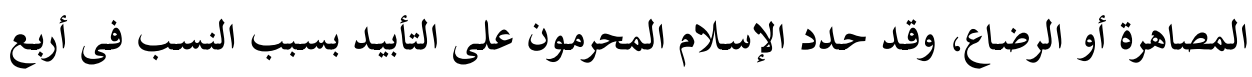

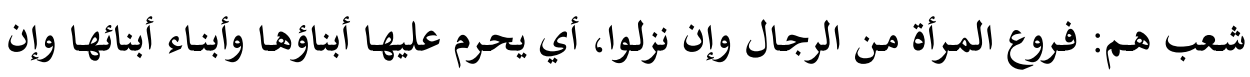

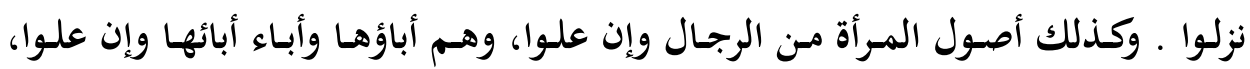

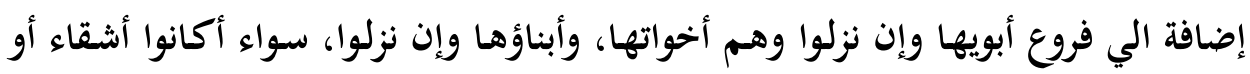

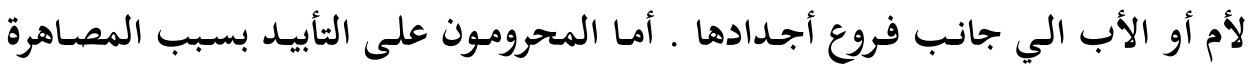

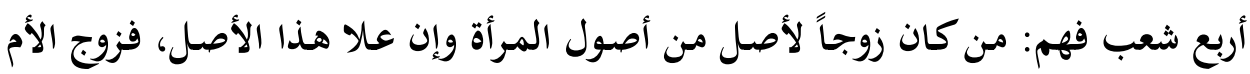

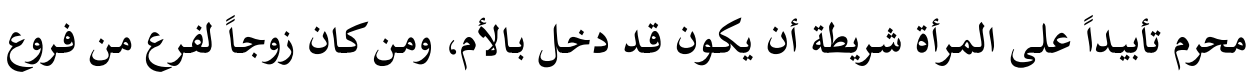


المرأة فزوج البنت محرم على المرأة، وإن لم يدخل بالبنت، أي أنه يحرم بمجرد العقد،

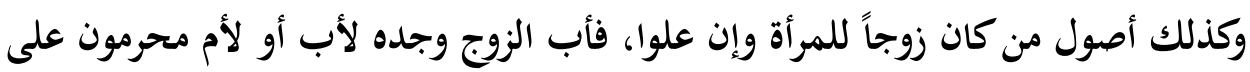

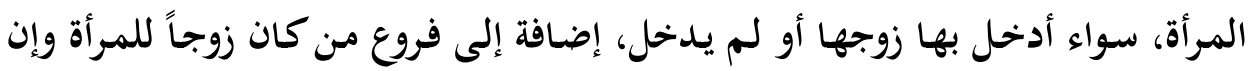

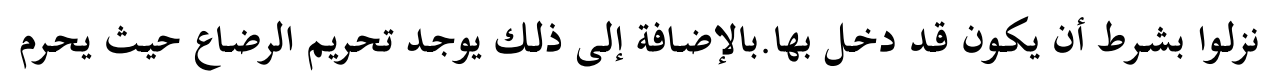

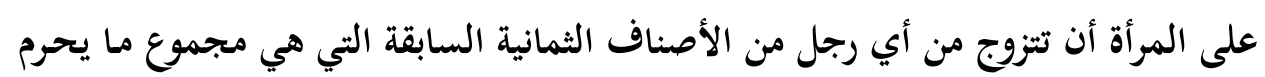

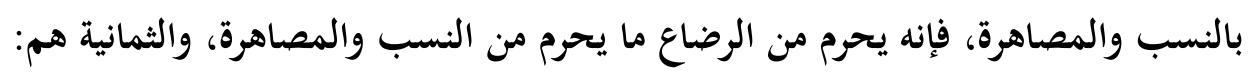

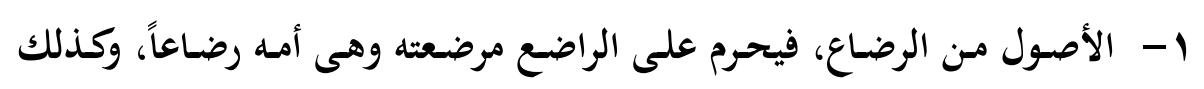

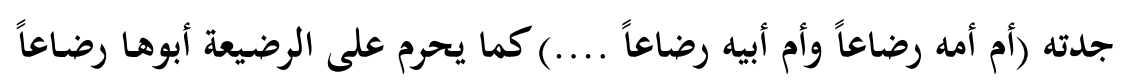
(وهو زوج المرضعة الشرعي عند الإرضاع) وجدها أبو أبيها، وأبو أمها رضاعاً.

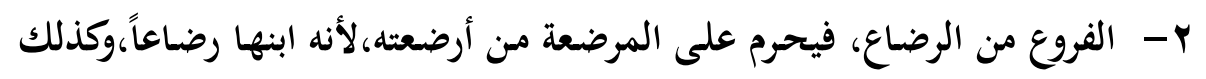

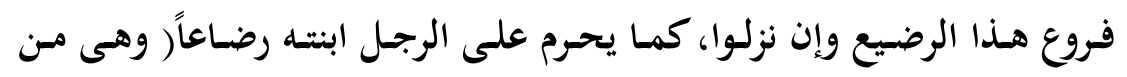

$$
\text { ب- أرضعتها زوجته)، كذلك فروع هذا الرضيع وإن نزلوا. }
$$

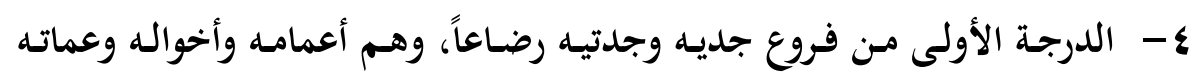

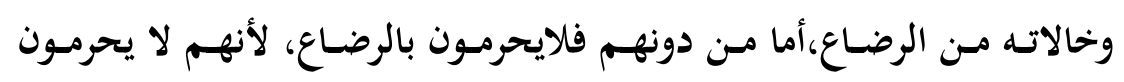
بالنسب. ه- أصول زوجته رضاعاً: كأمها رضاعاً، وجداتها من جهة أبيها أو أمها رضاعاً وإن علوا، سواء دخل بها أم لا كالنسب. צ- فروع زوجته رضاعاً: كبناتها وبنات أبنائها في الرضاع وفروعهم، وهذا إذا دخل

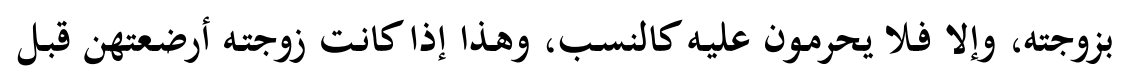

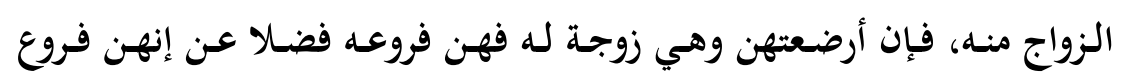
زوجته، والحرمه بينه وبينهن قائمة في الحالثين.

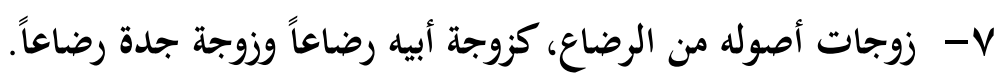




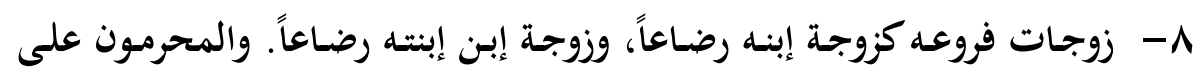

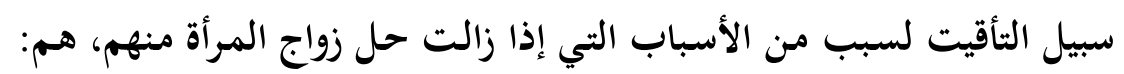

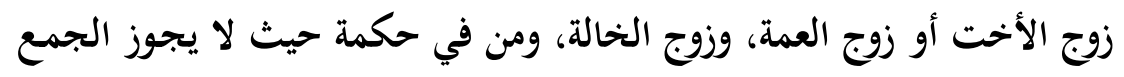

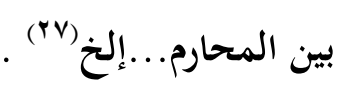

ويمكن تعريف المحارم إجرائياً بأنه: التحريم الأبدى للعلاقات الجنسية بين الرجال

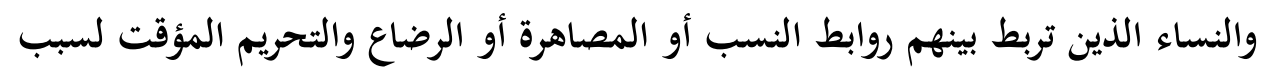

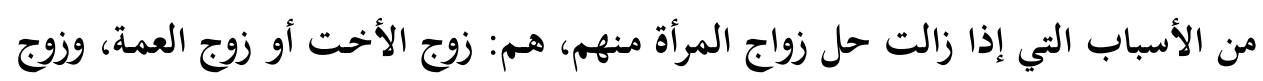
الخالة، ومن في حكمة حيث لا يجوز الجمع بين المحارم. رابعاً-الدراسات السابقة: ومن في تحة

حاولت الدراسات السابقة والتى اهتمت بتلك المشكلة البحثية تفسير معنى مصطلح المحارم ومن بين هذه الدراسات دراسة "محمد بن مرزوق العصيمي" بعنوان " مكافحة

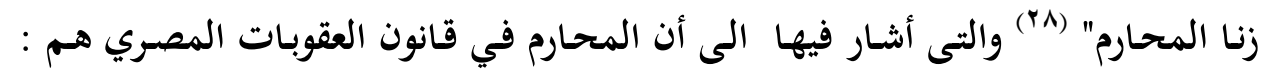

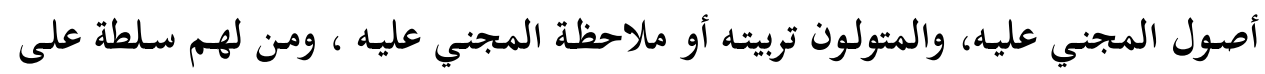
المجني عليه، والخادم عند المجني عليه أو عند من سبق ذكرهم. ولقد ذكر مركز النديم

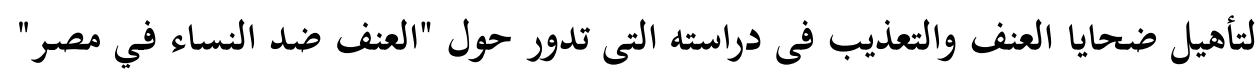

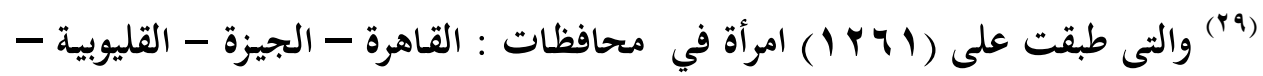

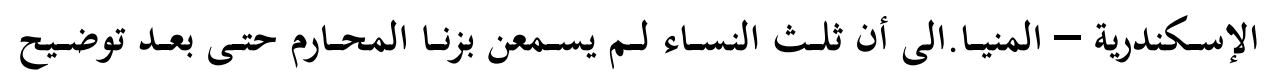
المقصود بـه، على حين ذكرت نسبة جو \% \% من النساء أنهن سمعن به، بينما أشـارت

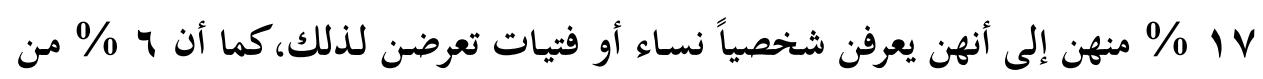

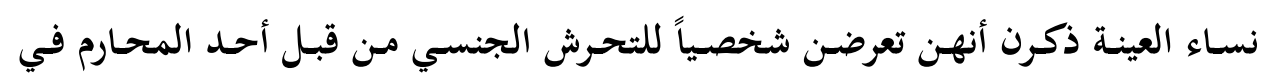
الأسرة.

ولقد سعت بعض الدراسات الى تحديد أشكال العنف الجنسي الموجهه للنساء من

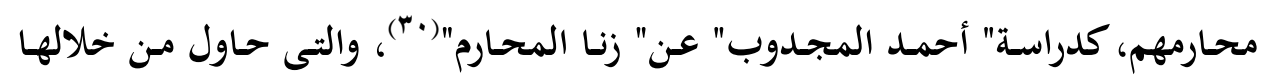




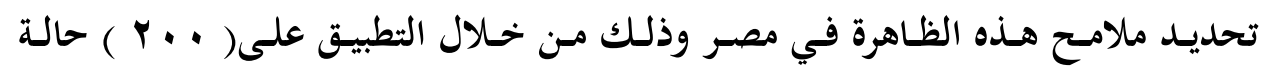

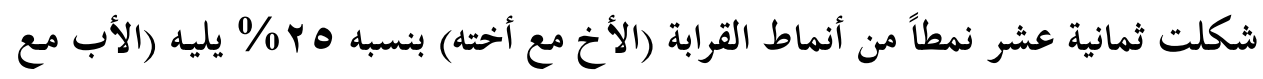

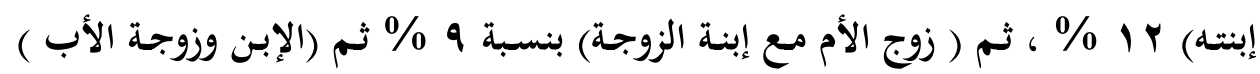

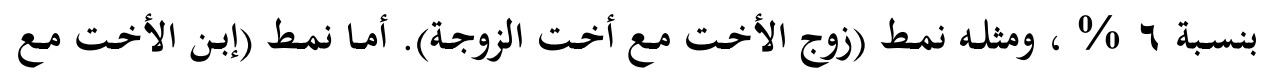

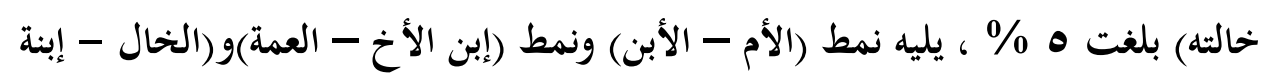

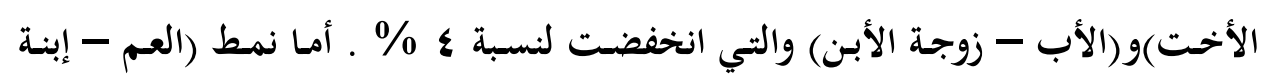

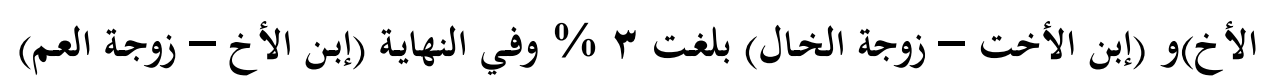

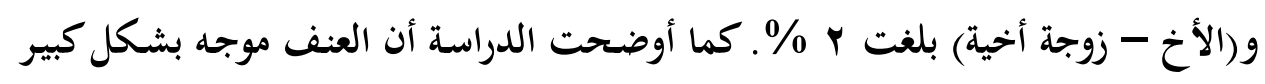

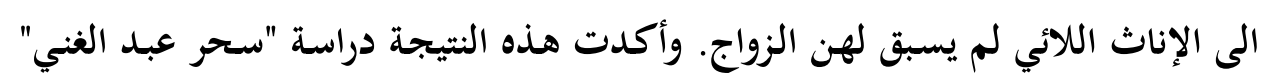

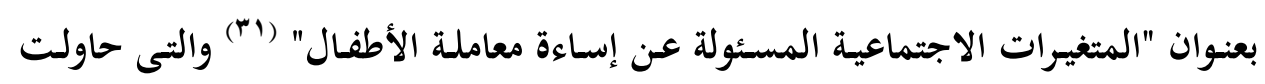

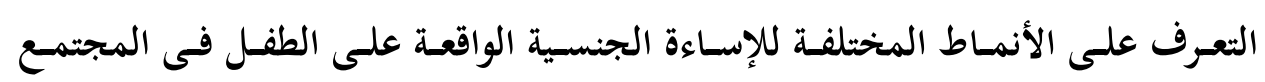

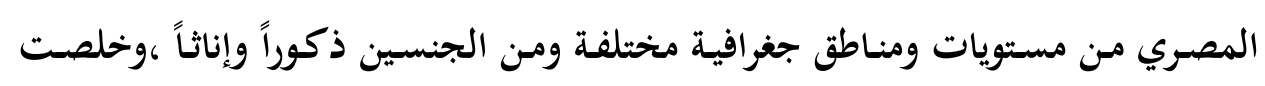
الدراسة الى أن نسبة ^, 9 \% من إجمالي العينة التى طبقت بمؤسسات الأحداث تعرضوا

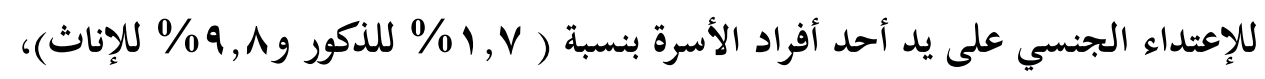

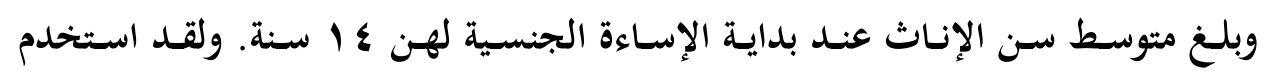
المعتدي العديد من الأساليب القاسية لإخضاع الطفل كالضرب والقوة والتهابل التهديد بالأسلحة البيضاء.

ولقد خلصـت دراسة كل من :محمد بن مرزوق العصيمي (r؟r) ، وأحمد المجددوب

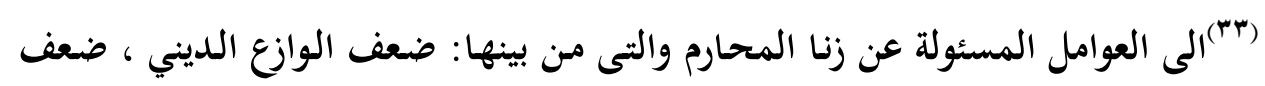

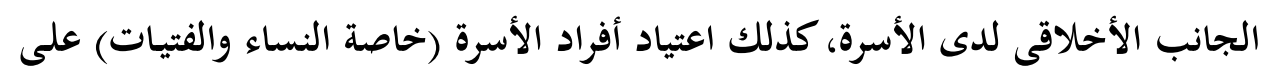

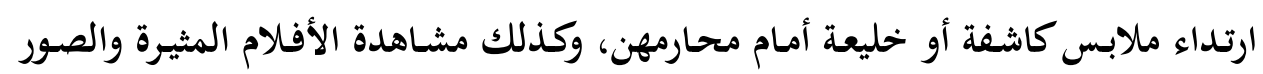

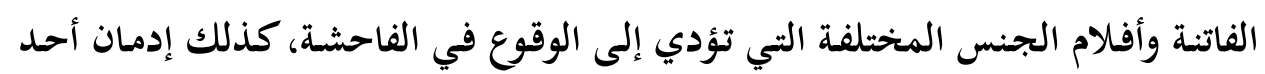
أفراد الأسرة الخمر والمخدرات. كما أن الإقامة في مسكن واحد الجد يعد عاملاً مهماً في 
وقوع زنا المحارم كما هو ملاحظ في زنا الأخوة بالأخوات والآباء بالبنات، حيث يرى

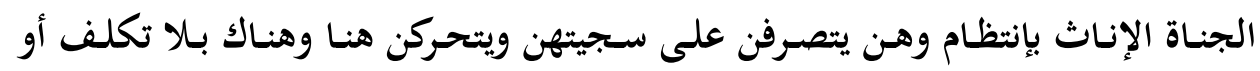

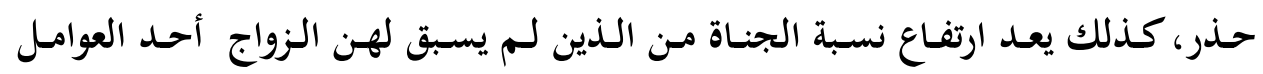

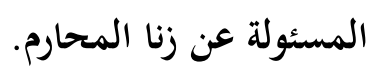

وأكدت دراسة "Nancy 1. fisher " بعنوان: عقدة أوديب: الحدود الأخلاقية

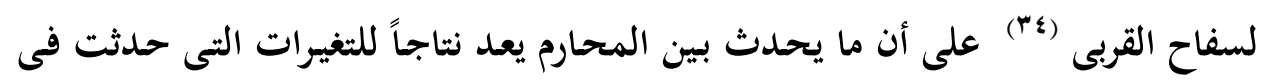
الأسرة والروابط التى تربط أفرادها مع بعضهم البعض وخحاصة فى المجتمعات الغربية التى لى لئى

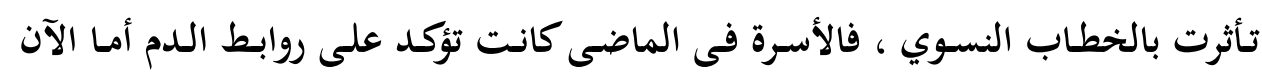

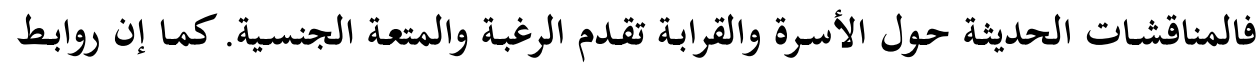

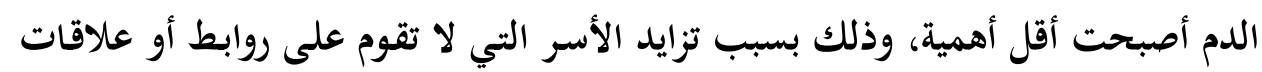
الدم وحلت محلها الروابط الأسرية المتنوعة التي ترتكز على الروابط والعلاقات القانونية،

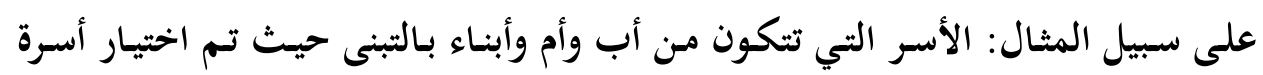

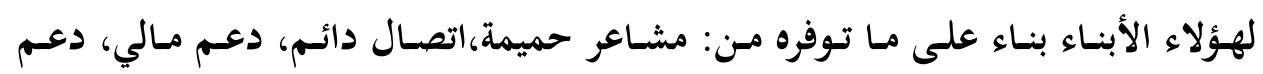
عاطفي. لـذلك رأى "Hyun_sil Kim في دراسـته حسول" خبـرات الاعتـداء بـين

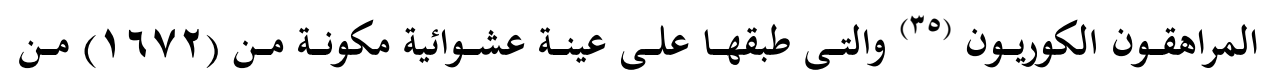
المراهقون أن الأسر التي وقع بها زنا المحارم اتسمت بنسبة مرتفعة من المشاكل، مثل: الاضطرابات النفسية والاكتئاب، والأعمال الإجرامية، وإدمان الكحوليات بين ألفات أفرادها.

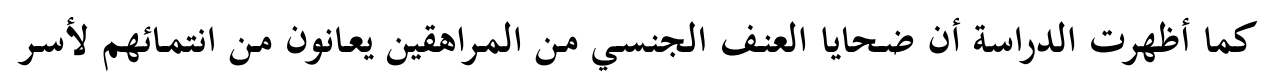
غير صحية وتعاني من الخلل الوظيفي والثفكك . ولا شك فى أن العنف الجنسي الموجه للمحارم يترك العديد من الآثار السلبية عليهم والتى أوضحتها بعض الدراسات كدراسة: Susan 1. Ray بعنوان "وجهات نظر

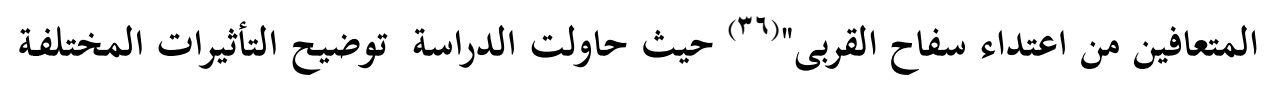


المترتبـة علـى زنـا المحــارم، والأشـكال الأخــى للإعتـــاء الجنسـي مـن وجهـات نظـر

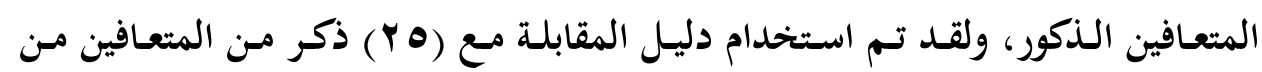

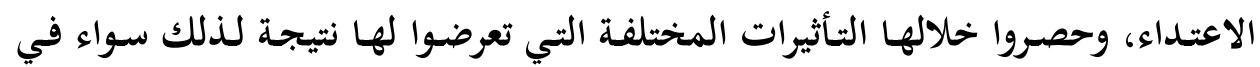
حياتهم النفسية أو العاطفية أوالجنسية أو الأسرية أو إحساسهم بالذات أوطبيعة علاقتهم بالرجال والنساء.خلصت الدراسة الى تعرض الحالات للعديد من التأثيرات من بينها:

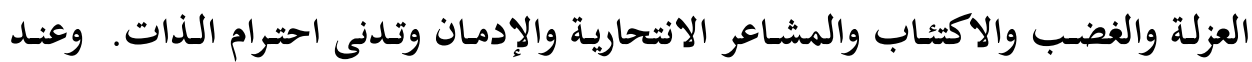
محاولة علاج الضحايا من تلك الثأثيرات نجد أن هناك العديد من المعوقات التى تحول دون ذلك ، ولقد ألقت دراسة" Donna Lewcowitz " بعنوان: "سفاح الآباء

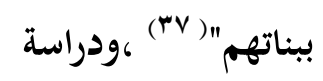

"De Rochemont" الاشتباه في زنا المحارم (38)، كذلك دراسة " Mary jayne" بعنوان : بعنوان:"سفاح القربى والاعتداء الجنسي على الطفل" (39)الضوء على تلك المعوقات، والتى من بينها: افتقاد

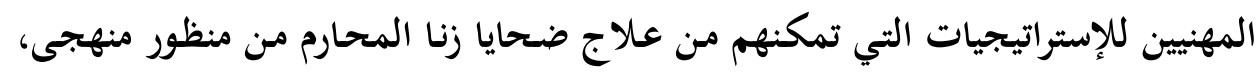

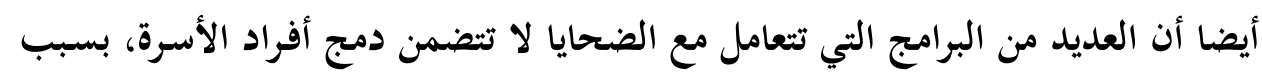

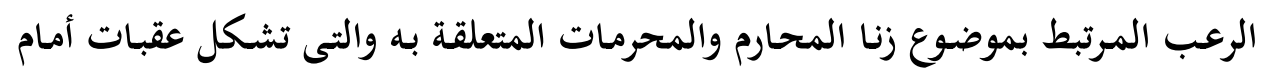
التدخل العلاجي مع أسر المحارم ( المعتدي عليهم).كذلك عدم استيعاب وفهم العاملين

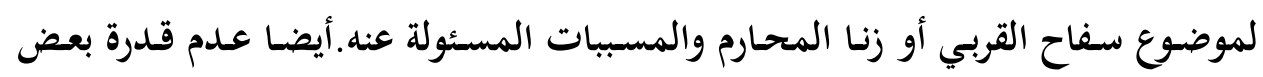
القساوسة على التعامل بصراحة وبشكل بناء مع هذا الموضوع. خامساً-التوجه النظري : تعددت الأطر النظية المفسرة للعنف الجنسي ضد المحارم فمنها ما يفسر أسباب

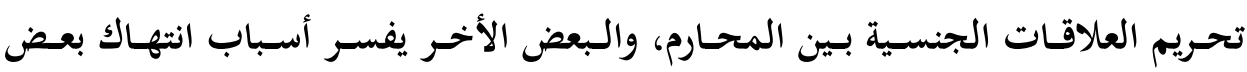

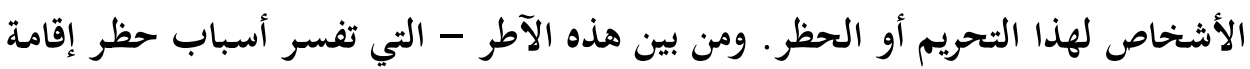

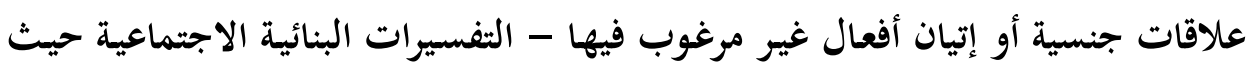


ذكر ليفي شتراوس أن سفاح القربى يعتبر إنتهاكاً للنظم الاجتماعية ويتداخل مع الأداء

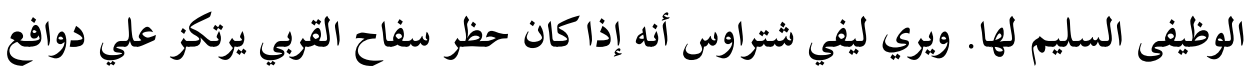

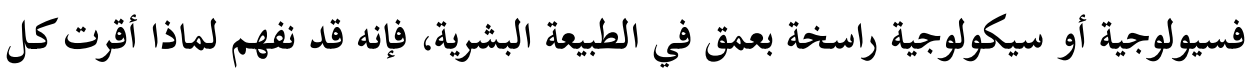

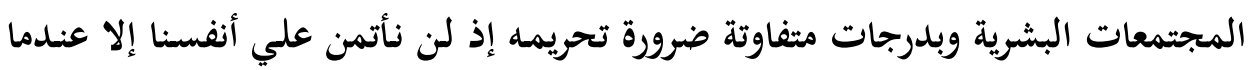
نخشي مما يفاجئنا (40)

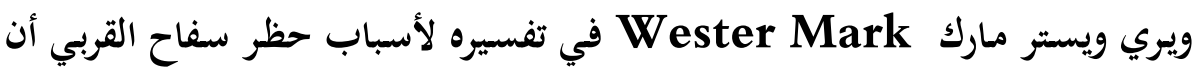
الأشخاص الذين يعيشون مع بعضهم البعض وتربطهم علاقات وثيقة يحملون مشاعر نفور فئني

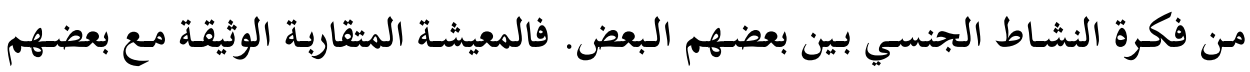

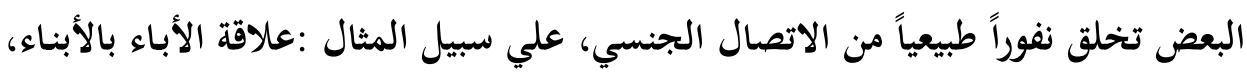

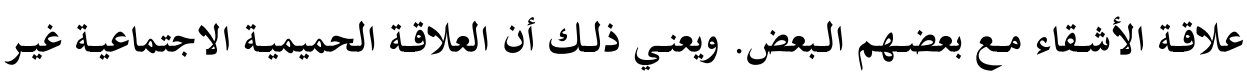

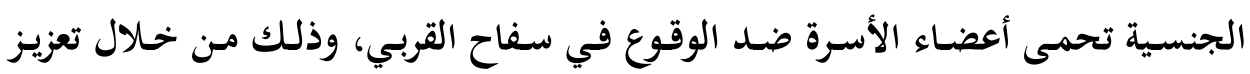

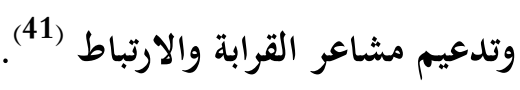
وتري مدرسـة التحليل النفسي أن هنـاك سلسـلة مـن الأعراف التي تمنـع الاتصـال

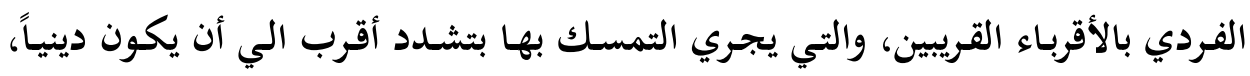

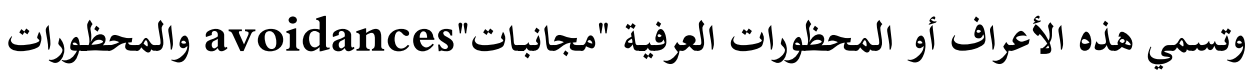

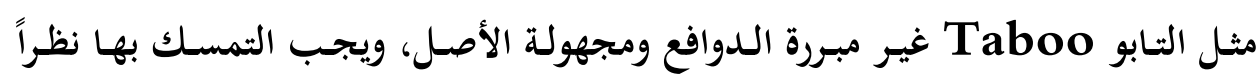

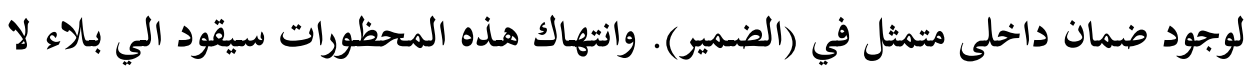
يحتمل (42). ويعني ذلك أن هناك عدة أسباب تقف وراء تحريم إتيان الأفعال والسلوكيات الجنسية

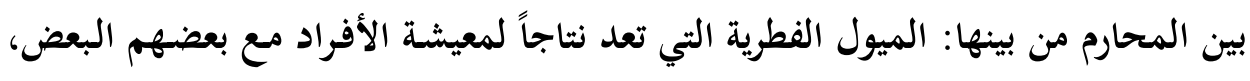

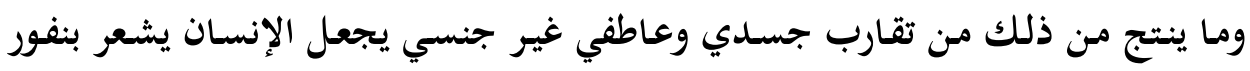

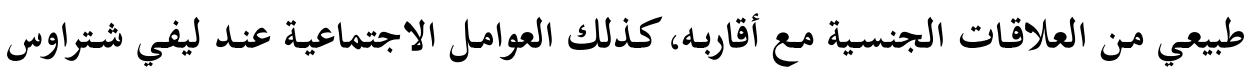

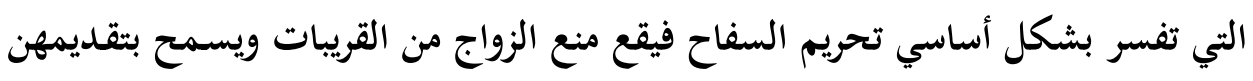


للزواج الي مجموعة أسرية أخري حيث تتقبل هذه المجموعات بدورها زوجات منها ـ أن

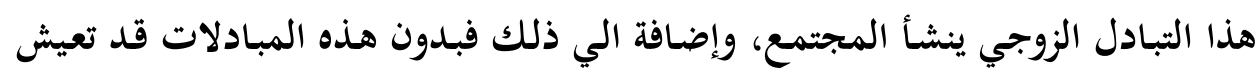
هذه الفئات منطوية علي نفسها (43). وتشسير مدرسة التحليـل النفسي الى أن سفاح القربي تحميه مجموعة مـ الأعراف

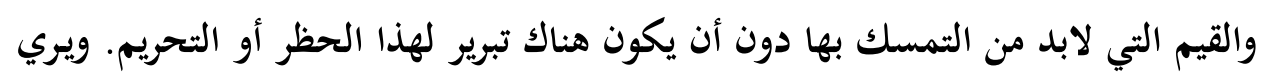

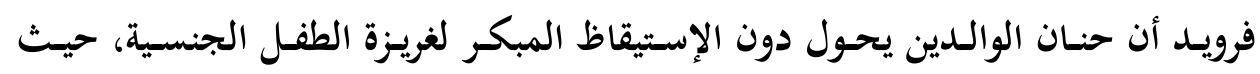
استطاع هذا الحب أن يفي بالمهمة المتوقعة منه، وهي توجيه خطي الطفل متي ما صار راشداً في اختيار الموضوع الجنسي، صحيح أن الطفل سينزع بطبيعة الحال إلي اختيار

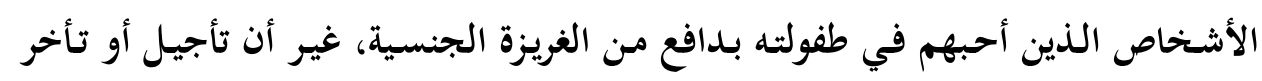

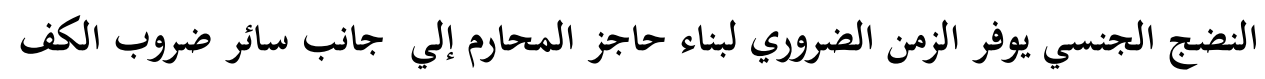

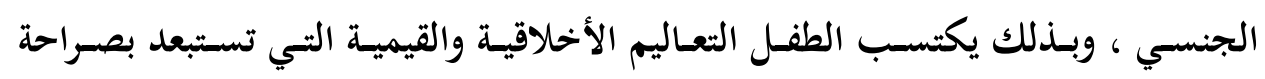
ووضوح الأشخاص الذين أحبهم في طفولته والذين هم من ذوي الأرحام. بيد أن التحليل النفسي يكشف لنا عن مدي الصراع الذي يتعين علي الفرد أن يخوض غمار فماره في مراحل

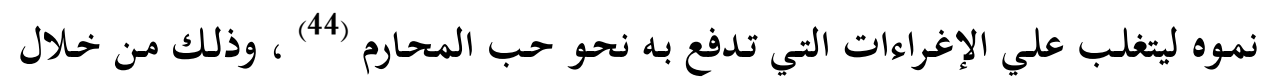

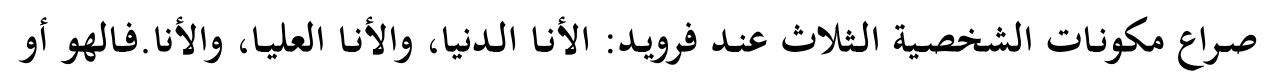

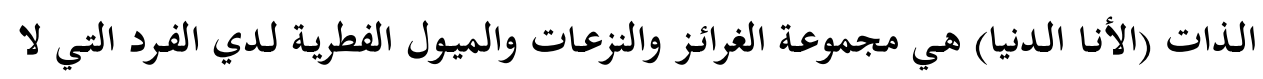
يتقبلها المجتمع، وهي مستودع الشهوات وهي تنساق وراء اللذه وإشباع الشهوات دون

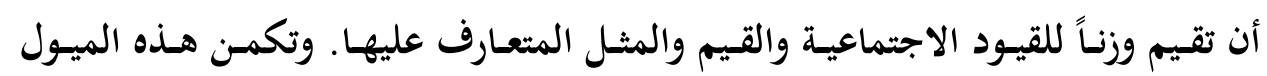

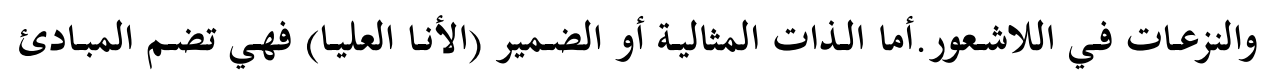

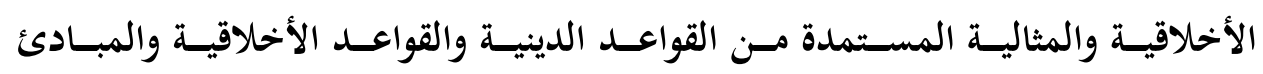

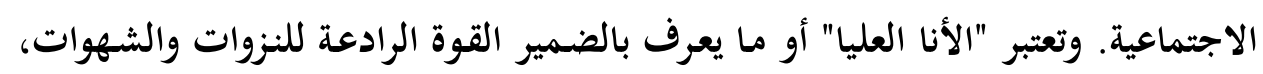

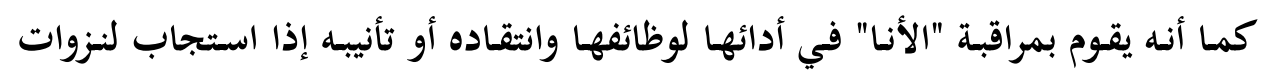

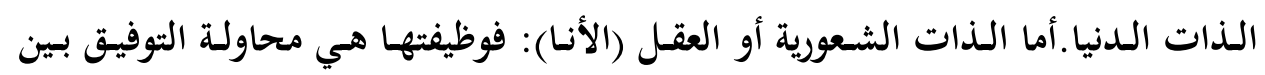


متطلبات الأنا العليا وبين النزعات الفطرية الغريزية التي تصعد من الذات الدنيا. ولقد قسم فرويد (الأنا) إلي قسمين هما الشعور واللاشعور وهذا الأخير يستوعب كل الأل الأفكار والخواطر والميول والرغبات التي لا تظهر إما لمخالفتها التقاليد والآداب والعقائد الدينية

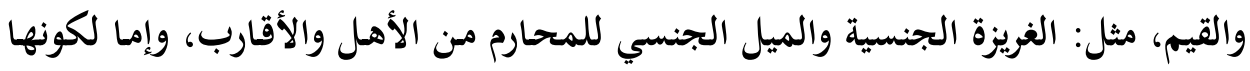
من قبيل الذكريات المؤلمة التي لا يرغب الإنسان في تذكرها.

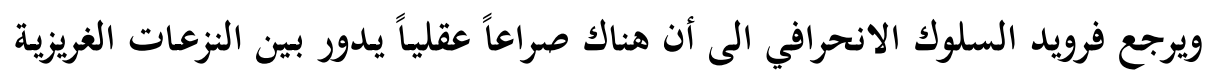

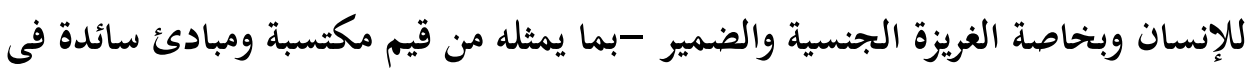

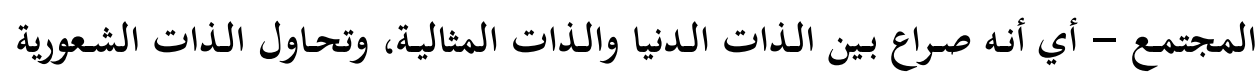

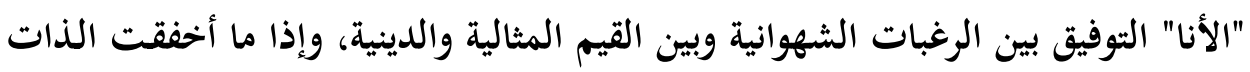

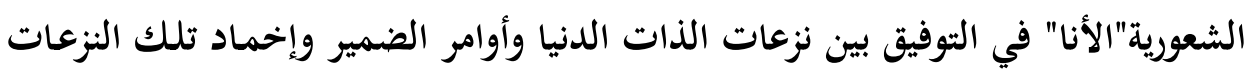
في اللاشعور، فإن الشخص ربما يسلك سلوكاً انحرافياً من أجل التعبير عن ميوله ورغباته الفطرية، وفي هذه الحالة تكون الذات المثالية (الضمير) منعدم الوجود أو ضعيفاً عاجزاً

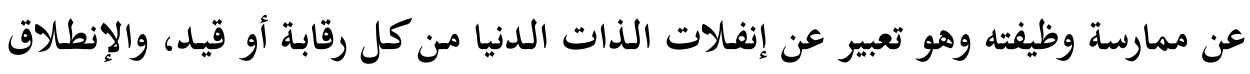

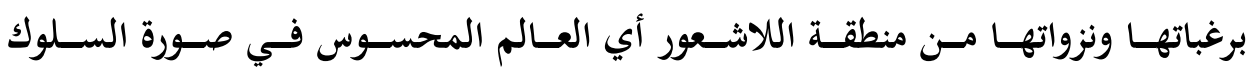
الإنحرافي (45).

ويعني ذلك أن الثخص الذي يرتكب العنف الجنسي ضد المحارم قد حدث للأنا

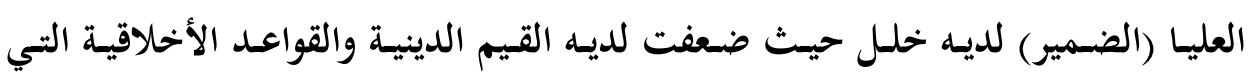

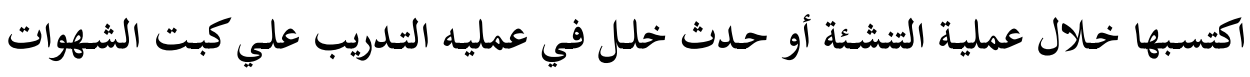

$$
\text { والميول الجنسية غير المشروعة. }
$$

ويري بعض العلماء أن ذلك يعد نتاجاً لما يسمي بالإضمحلال الأخلاقي أو الوهن

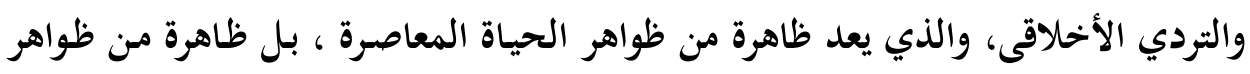

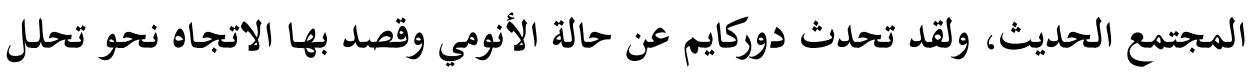

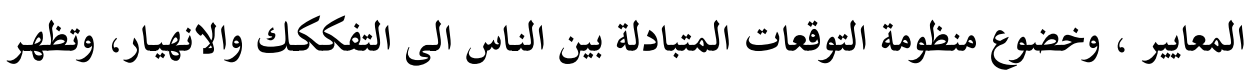


هذه الحالة فى أوقات التغير السريع، حيث تتعرض المنظومة الاجتماعية الى ضغوط تهدد

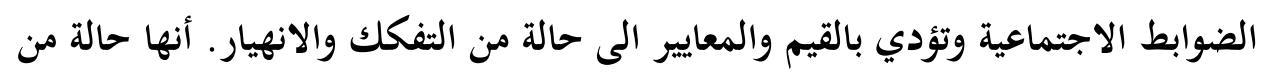
فقـدان المعـايير Mormlessness تلـبس المجتمعسات عنسدما تسـود فيها الفرائزز وتتحلل الأطر الثقافية والهعيارية العامة، ويترك الأفراد كل على هواه دون ضوابط أخلاقية تدفع بـه إلى تحقيق أهدافه وتمييز السلوك الصواب من السلوك الخطأ. ويترتب علي

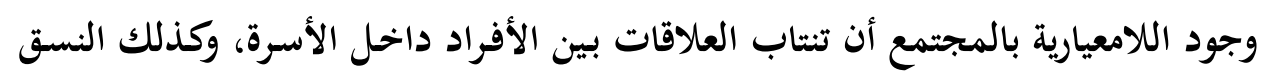

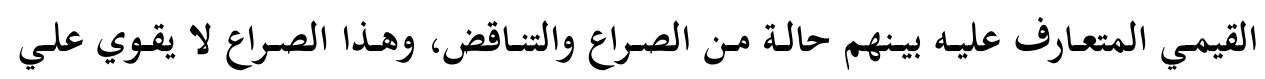

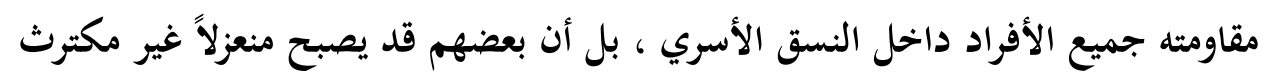

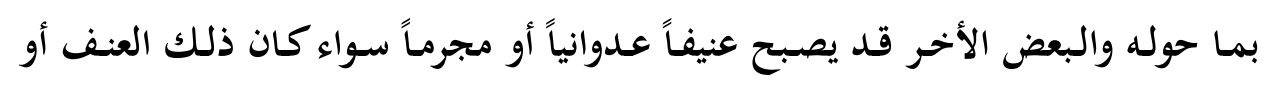

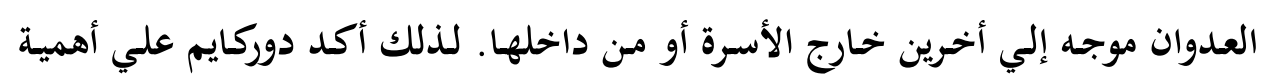

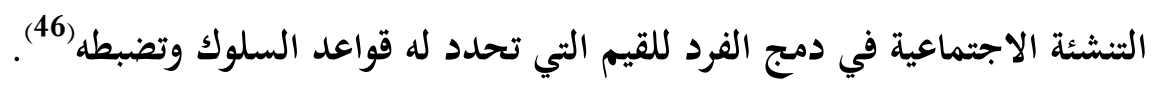

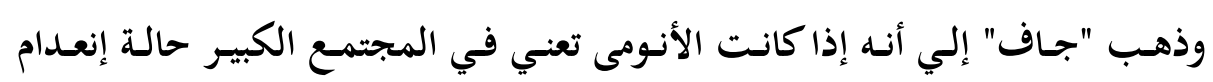

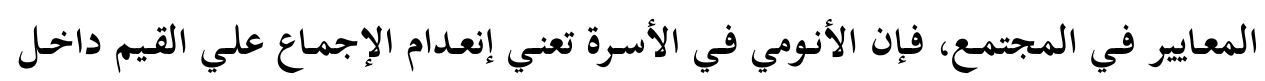

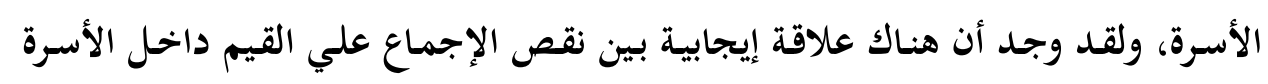
وبين الميل إلي الإنحراف والعنف (47) .

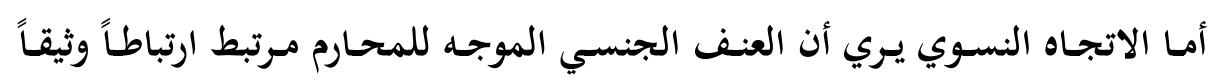

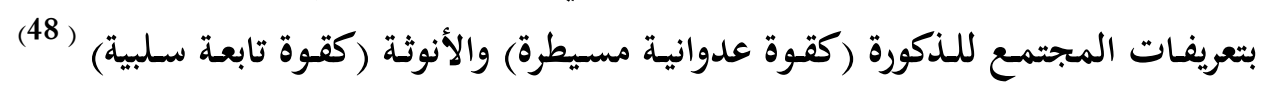

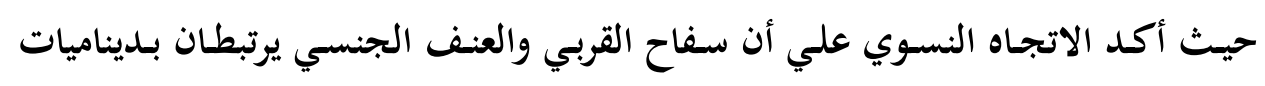

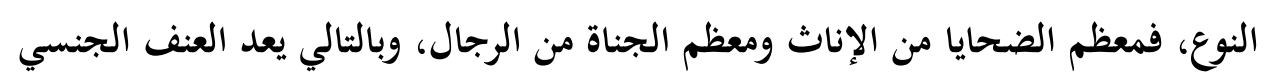

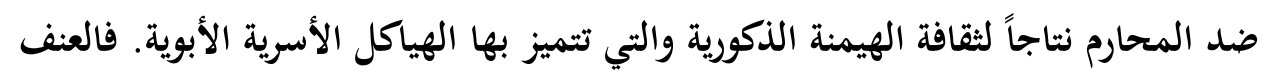
الجنسي يعكس المعايير الجنسية الذكورية المرتبطة بقوة وبراعة وهيمنة الجنس، كما أنه

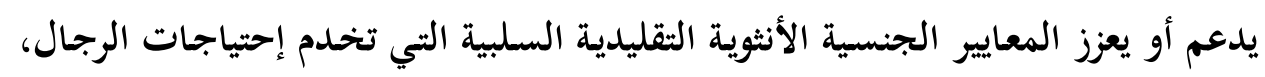
فالعائلات التي يحدث بها سفاح القربي لديها أدوار نوعية واضحة حيث يكون الأب لديه 
سـلطة مطلقــة وإحســاس عميـق بالاسـتحقاق ويتوقـع تلبيـة أو طاعـة طلباتـه أو مطالبـهـ واحتياجاته من قبل زوجته وأطفاله الإناث. كما أكد الاتجاه النسوي علي أن سفاح القربي

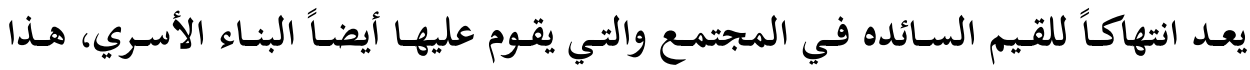
بالإضافة الى نظرته للعنف والإعتداء ضد المحارم باعتباره نتاجاً لخيانة الأمانة، وخيانة الثقـة، وإسـاءة لاستخدام السـلطة والإسـتغلال ، وهـو مـا يشسير إلي حسدوث خلـل فيل في المنظومـة القيميـة داخل الأسرة وفي العلاقات الاجتماعية المبينة علي الحمايـة والأمس

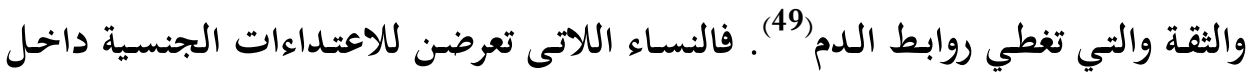
العلاقات المبينة علي الثقة تكشف عن فقدانهن القوة وعجز موقفهن علي الرغم من المحاولات المختلفة بينهن لمقاومة تلك الاعتداءات، ففي محيط الأسرة النووية النساء

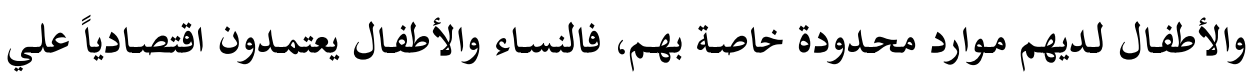

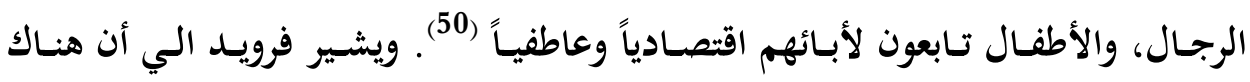

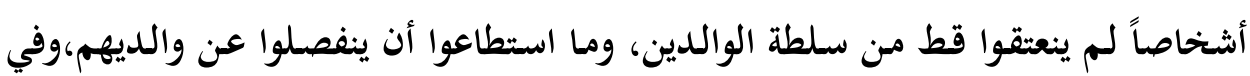

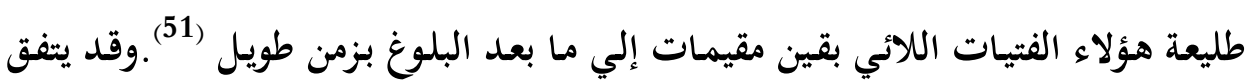

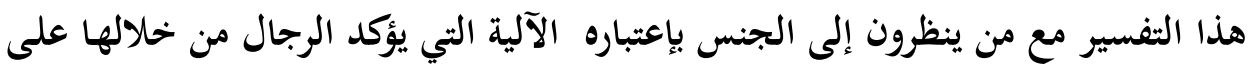

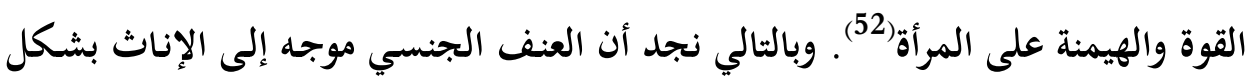

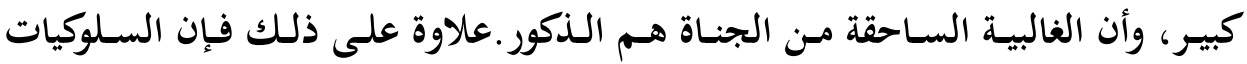
الجنسية هي في حد ذاتها إحدى الممارسات الاجتماعية للرجولة(53) ويوضح Albert Bandura الكيفية التى يتعلم بها أفراد المجتمع السلوكيات والممارسات ، ويري أن الأفراد يتعلمون السلوكيات من خلال ملاحظة الآخرين فى بيئتهم

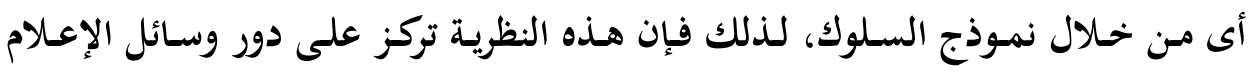

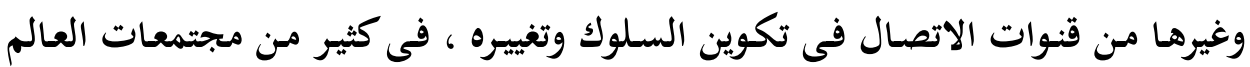

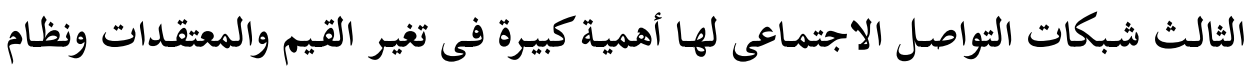
الأعراف الاجتماعية ويختلف الأشخاص عن بعضهم البعض فى التأثر بتلك الوسائل . 
وموقف العنف قد يكون مرتبطاً طبقاً للنظية بالافتقار الى الفاعلية أو الكفاءة الذاتية التى

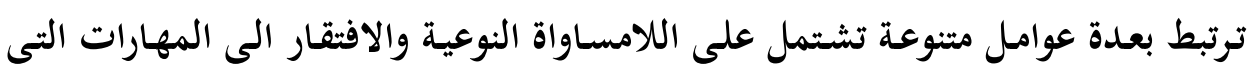

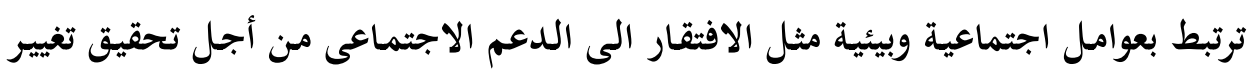
موجه نحو الذات (54) تونيط بعول اجتماعة سادساً- الإجراءات المنهجية للدراسة: 1- منهج الدراسة: تنقسم الدراسة الي جزءين :الجزء الأول والذى نقوم فيه بالنطبيق

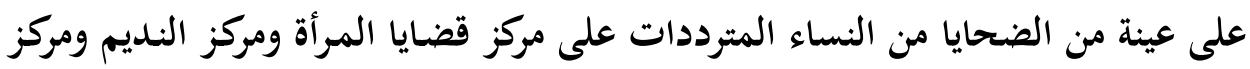
القاهرة لحقوق الإنسان (55) ـبالإضافة الى التطبيق على عينة من العاملين الذين يتعاملون بالفعل مع حالات العنف الجنسي ضد المحارم ، إعتمدنا فيه على المنهج الكيفي في

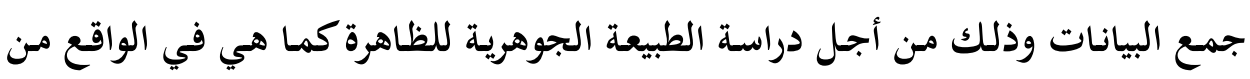
أجل الوصول إلى تفسيرات موضوعية للمعطيات اللفظية التي يسفر عنها البحث.

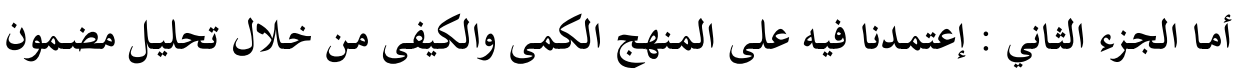

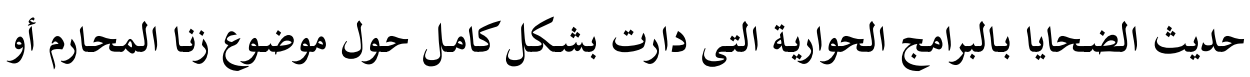

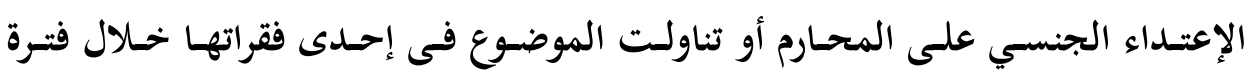

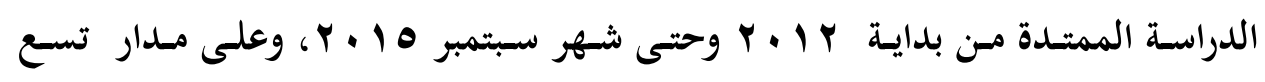
حلقات، ولقد تمت إستضافت عشر حالات. ولقد إعتمدنا على تحليل مضمون الحوار

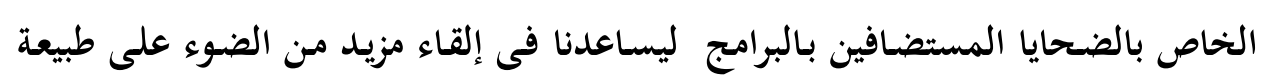

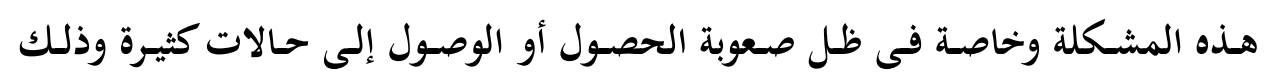
لحساسية الموضوع. : بأدوات جمع البيانات

إعتمد الباحثان فى الجزء الأول من البحث على المقابلة المتعمقة من خلال تطبيق دليل المقابلة مع (7) حالات من ضحايا العنف الجنسي من المترددات على مركز قضايا

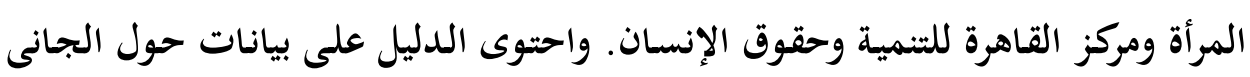


والضحية ومعلومات حول طبيعة الاعتداء الذى تعرضت له الحالات ورد فعل الضحية

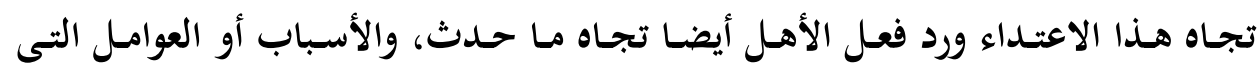
ساهمت أو دفعت الجانى لارتكاب جريمة العنف الجنسي ضد أحد محارمه من وجهة

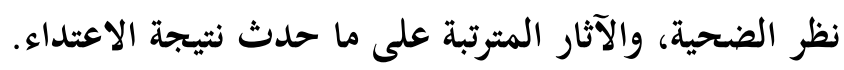

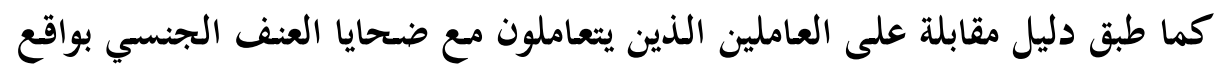

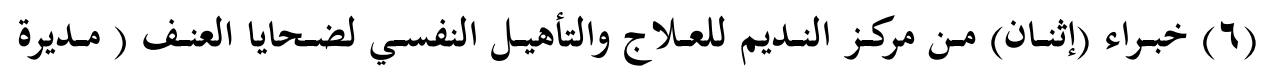

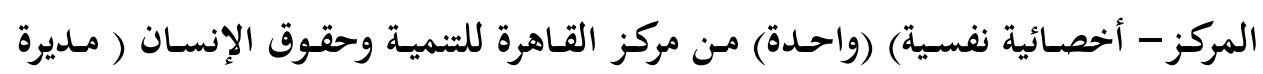

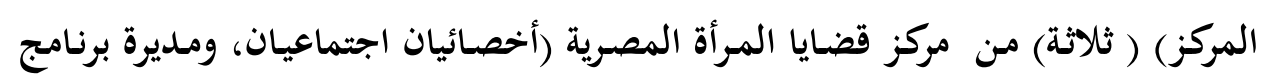
مناهضة العنف ضد المرأة ). احتوى الدليل على بيانات أساسية عن إسم المركز الذى ينتمى إليه الباحث ومهنته

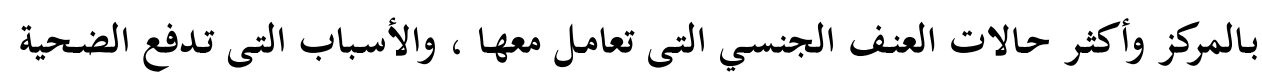

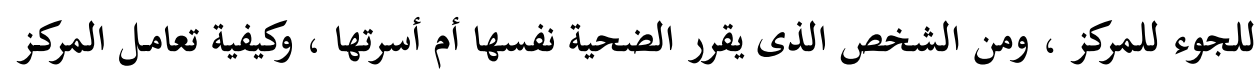

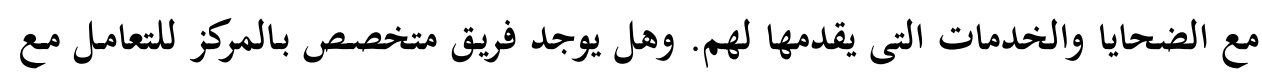

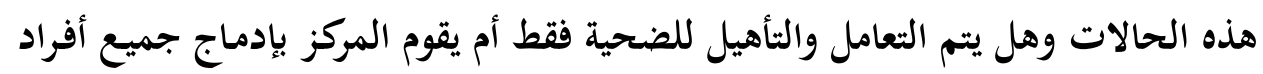
الأسرة فى العلاج، أيضـا مـا موقف الأسر مـ الاعتـداء على الضـحية هـل تلوم الأسـرة

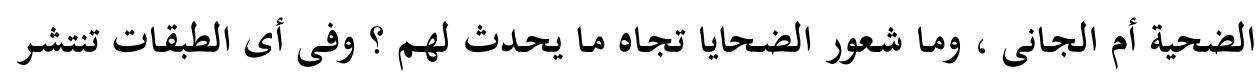

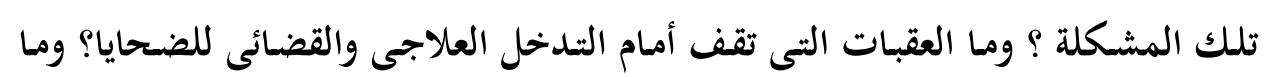
موقف القانون المصري من ضحايا العنف الجنسي ضد المحارم وهل تتناسب الأحكام

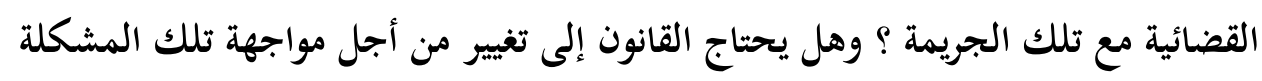

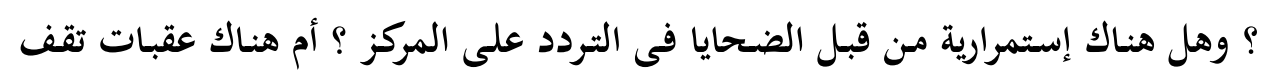

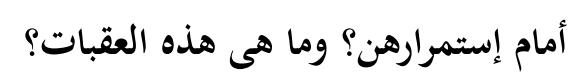

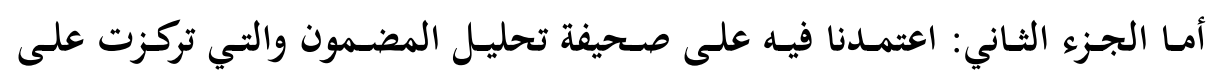
الضحية والجانى واشتملت علي بعض العناصر الأساسية وهي : السن والحالة الاجتماعية 


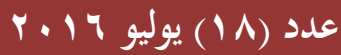

والمهنية وذلك للجانى والمجني عليه،ووصف المسكن المقيمة به الضحية، طبيعة العنف الجنسي الموجه للضحية،أيضا صلة القرابة بين الجاني والضحية، وأسباب إرتكابه لمثل ذلك الفعـل، أو الظروف التى سـاهمت فى وقوع التحرش أو الاعتـداء الجنسي على الضحية، والآثار المترتبة على ذلك الاعتداء بالنسبة للضحية. وقد تم تحليل البرامج الحوارية بواقع (9) برامج تم عرضها في الثلاث سنوات الأخيرة

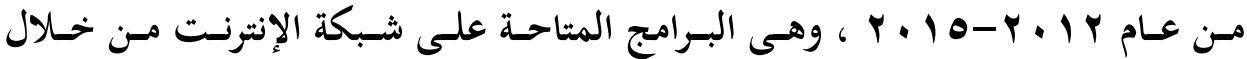
ال youtube ولم يجد الباحثون أى برامج ناقشت أو عرضت لهذه المشكلة قبل ذلك التاريخ. وتركز موضوع التحليل علي جرائم العنف الجنسي الموجه ضد المرأة والتي

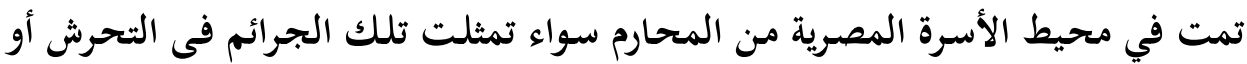

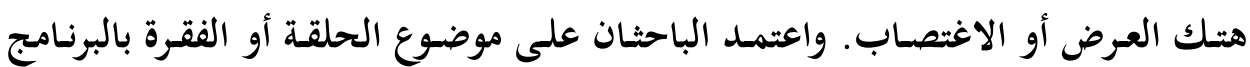
والذي يتعلق بجرائم العنف الجنسي أو زنا المحارم أو سفاح القربى التى ترتكسب في محيط الأسرة بين الضحية ومحارمها. هذا بالإضافة الي إختيار الشخصية كوحدة للتحليل سـواء كانـت شخصسية الضـحية أو شخصسية الجـاني أو والـدة الضحية.واشتملت فئسات التحليل علي ما يلى: الخصائص الديموجرافية للمعتدى والمعتدى عليها : السن، المهنة

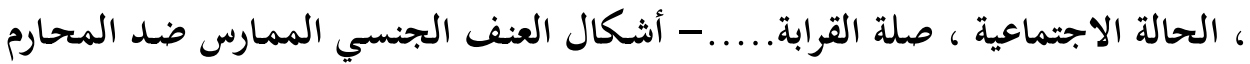

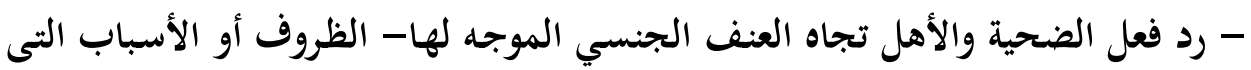

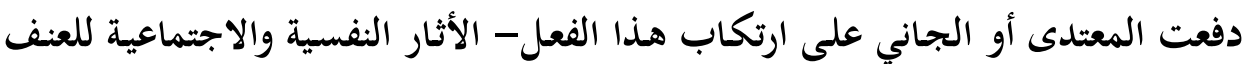

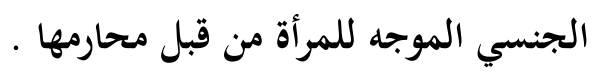

وقام الباحثان بتحليل البيانات تحليلاً كمياً وكيفياً، وذلك من أجل التعرف علي طيل طبيعة هذه المشكلة وأسبابها، وإلقاء الضوء على الصورة التي تناول بها الإعلام هذه المشكلة.

$$
\text { سابعاً- - نتائج الدراسة: }
$$

أ- نتائج المقابلة المتعمقة مع الضحايا المترددون على المراكز المعنية بتقديم الخدمات 
1- الخصائص الديموجرافية للضحايا والجناة:

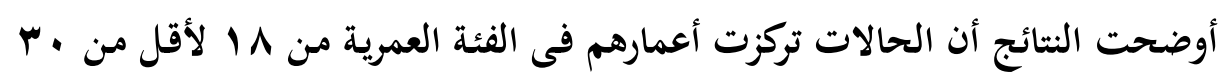
بواقع (ثلاث) حالات، و(حالتان) للفئة العمرية أكثر من • ب سنة ، ( وحالة واحدة) للفئة

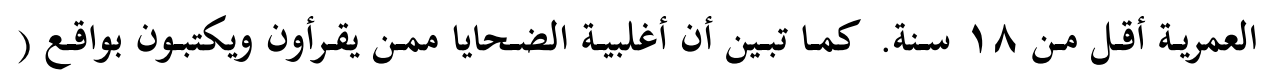
ثلاث) حالات، أو أميون ( حالة واحدة)، وحاصلون على مؤهل متوسط( حالة واحدة) أو

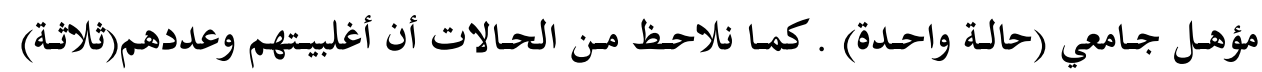

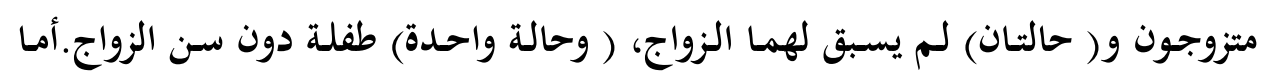
بالنسبة لصلة القرابة بين الجاني والضحية تبين أن العنف الجنسي الموجه للمحارم كان

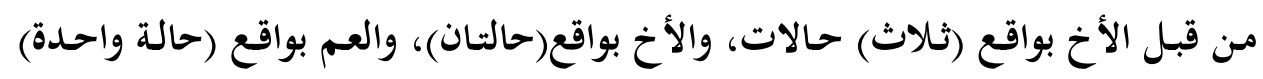
لكال منهما. وفيما يتعلق بطبيعة العنف الجنسي الموجه للمحارم يمكن القول بأنه تركز فى الاغتصاب وهتك العرض والتحرش الجنسي بواقع حالتان لكل منهما.

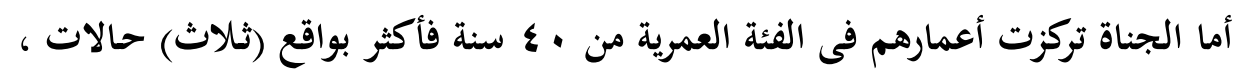

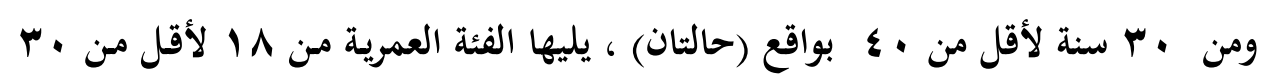

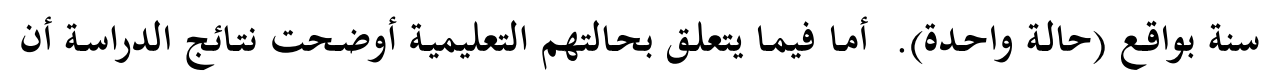

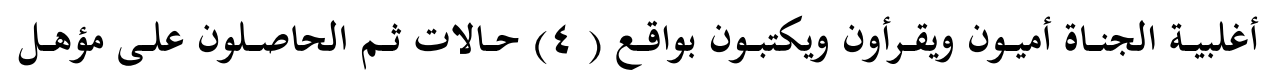

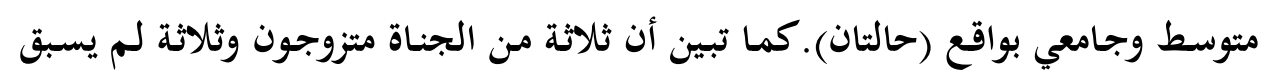

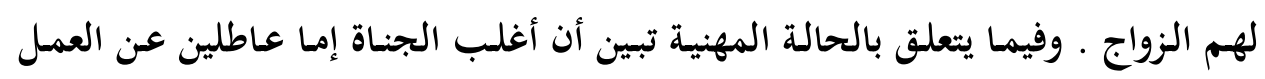
بواقع (ب) حالات ، وإما يعملون فى مهن هامشية كبائع متجول أو سائق بواقع (حالثان)،

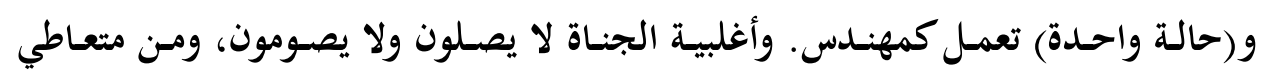

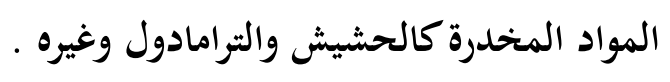

وفيما يتعلق بالمسكن يقيم (ثلاث حالات) فى مناطق حضرية شعبية وعشوائية غير

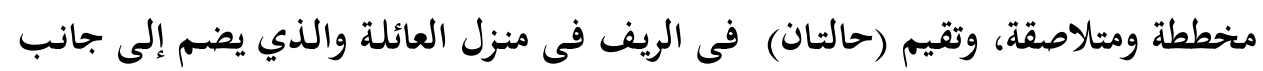

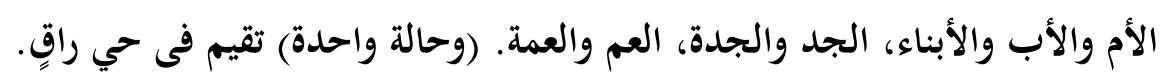


Y - طبيعة وأشكال العنف الجنسي التى تعرض لها الحالات : الاتل

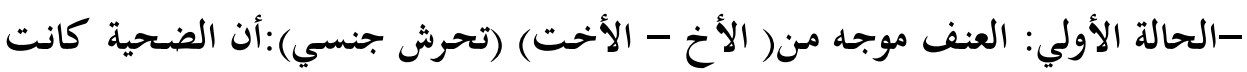

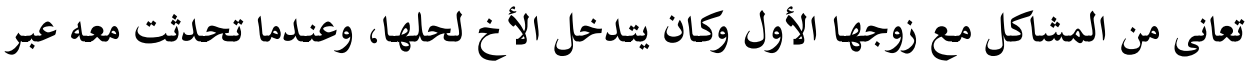
الثليفون من أجل أن يذهب إليها أبدى رغبته فى أن تذهب هي إليه وتخبره ما حدث مع إنع زوجها، فوافقت. وعندما ذهبت حاول أن يعتدى على أخته فى غياب الزوجة ، وتعبر عما

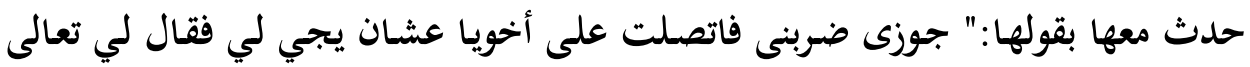

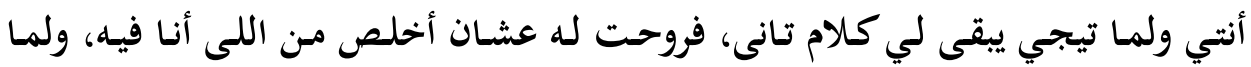
دخلت قلت له مراتك فين قالى جوه، قلت له خش صحيها، قالى مش آدر أصحيها خشي أنتى صحيها ، قمت أصحيها ما لقتهاش قولت له هى فين؟ قالى مراتى مش هنا وخفت أقولك مش هنا ماتجيش فقعد وحكيت له اللى حصل من جوزى وقعدت أعيط، فطب طب عليا ومد أيده على جسمي وبسنى بوسة غريبة ". وكانت هذه أول مرة يحاول

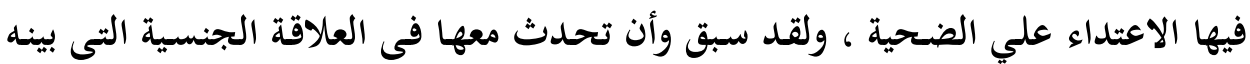

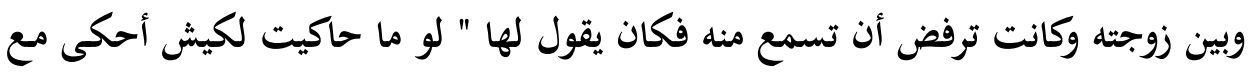
مين.......دايما خناقـات مـع مراته وواقفين على الطلاق عشـان مـا بتخلهوش يلمسهـا

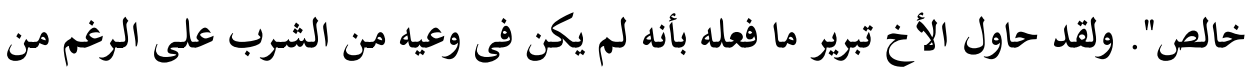

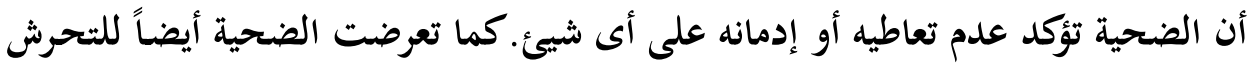

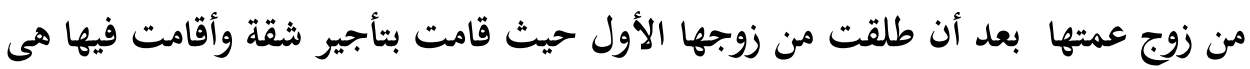
وأبناؤها وبسبب كثرة المصاريف تعرضت لضمائقة مالية فذهبت إلى عمتها من أجل أن أن

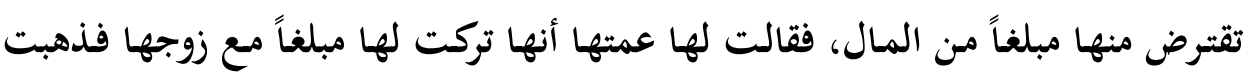

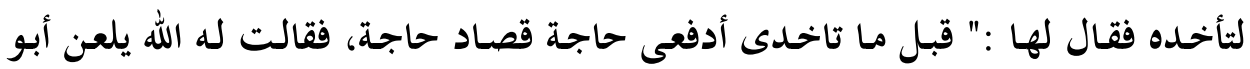
الحواجة اللى بتحوج الناس ومشيت وجاتلى عمتى كذا مرة تقولى أيه اللى حصل قلت لها

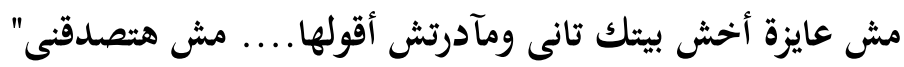


- الحالة الثانية: العنف موجه من( الأب- للإبنة) (إغنصاب): الأب مقيم بشكل دائم

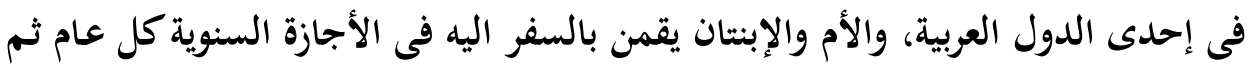

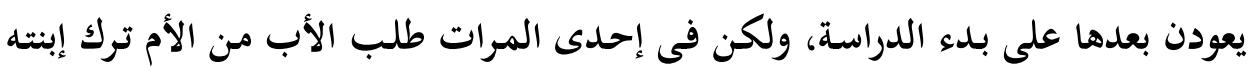

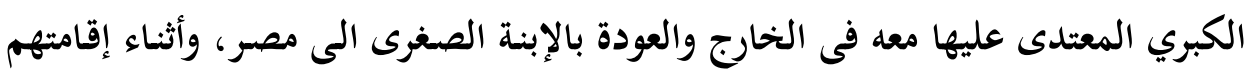

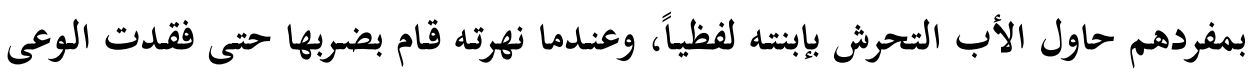

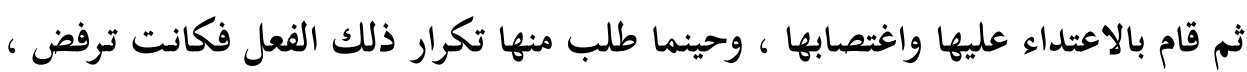

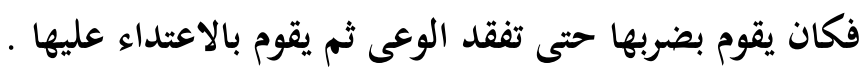

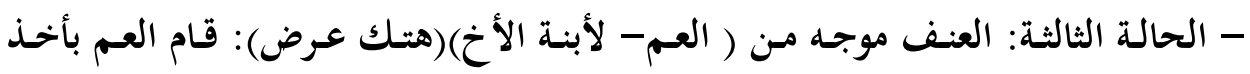

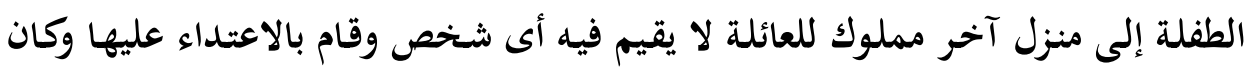

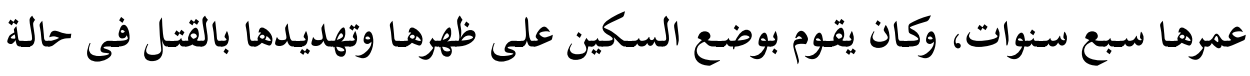

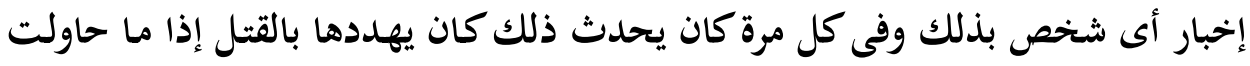

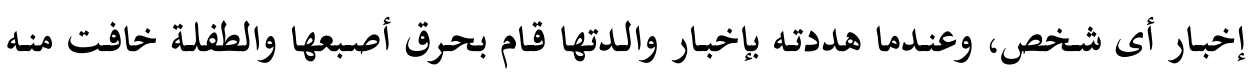

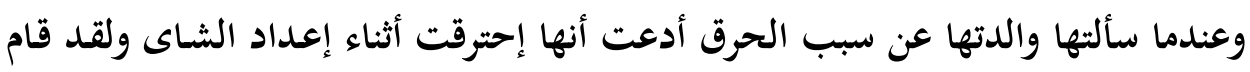
بالإعتداء عليها أكثر من عشرين مرة".

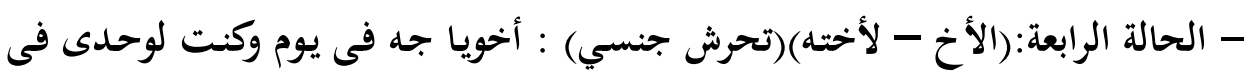

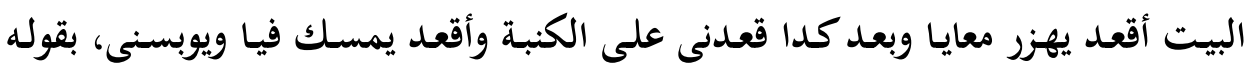

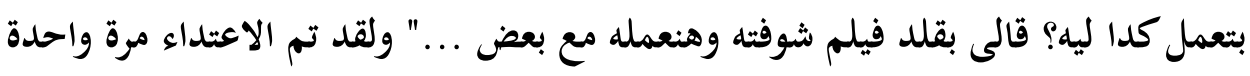
وكان عمرها عندما حدث ذلك سبعة عشر عاماً.

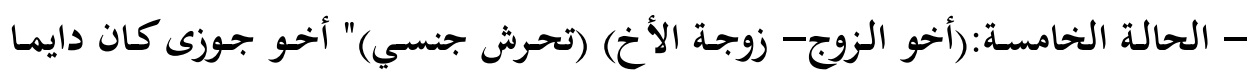

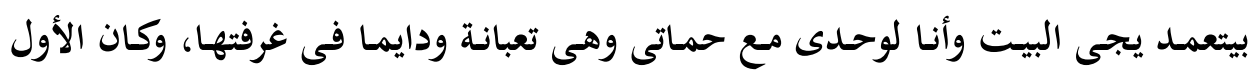

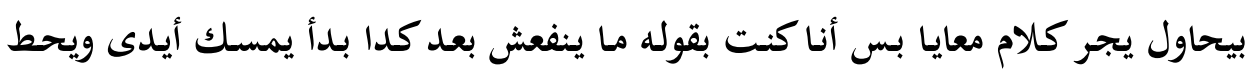

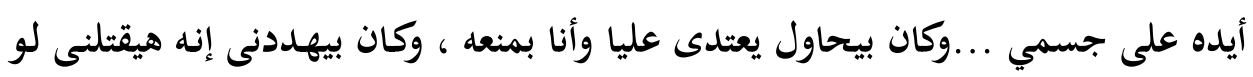

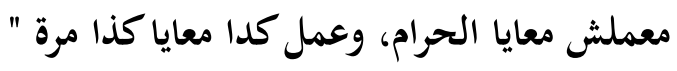




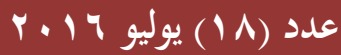

- الحالة السادسة: "( الأب- الأبنة) (إغتصاب) : أبويا كان بيدخل عليا الآوضة من غير

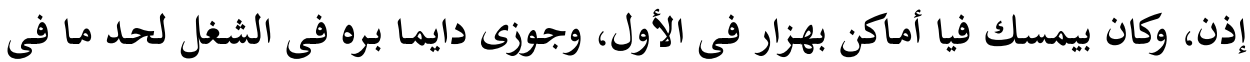

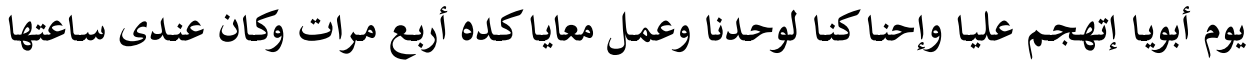
ا Y سنة" .

ب- رد فعل الضحايا وأسرهم تجاه ما حدث : ألماث أغلب الحالات لم يستسلموا فى بـادئ الأمر، ولكن تحت ضغط التهديد والضرب إستسلم معظم الضحايا للعنف الجنسي. ومن لم تستسلم إعتمدت على وعيها الكامل بأن ما يحدث خطأ وحرام، بالإضـافة إلى قدرتها على أن تسيطر على زمام الأمور من خحلال تهديد المعتدي بفضحه، وتعبر عن ذلك إحدى الحالات التى حاول أن يعتدي

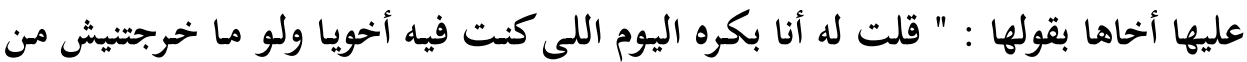

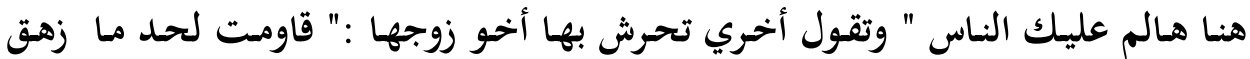
وبعدين عرف واحدة...." ولم يحاول الضحايا الإبلاغ عن المعتدي خوفاً على سمعتهم

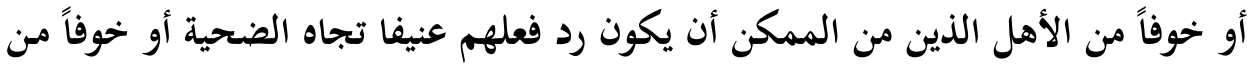

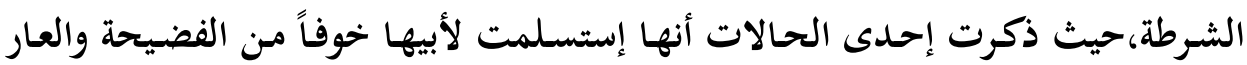
الذى سيلحق بها وبالأسرة لو عرفت أمها أو زوجها أو أى شخص أخر، كما أنها خافت

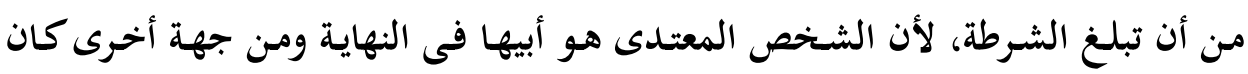

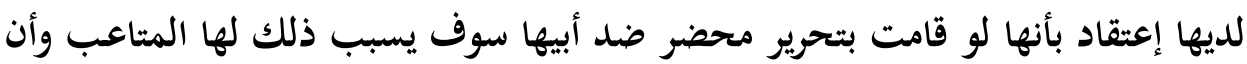
الشرطة " هاتبهدلها.

وفضل بعض الحـالات الصـمت ولم يبلغوا أي شـحص من الأهـل عمـا حـدث معهم

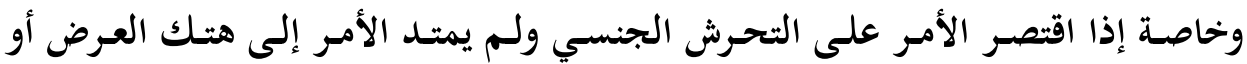
الإغتصـاب. وتعبـر عن ذلك إحـدي الحـالات بقولها: "عشـان أخويـا هـابلغ عن أخويـا ماينفعش.... مـافيش أى حـد يعرف غير الأخصائية الاجتماعية فى مركز قضـايا المرأة

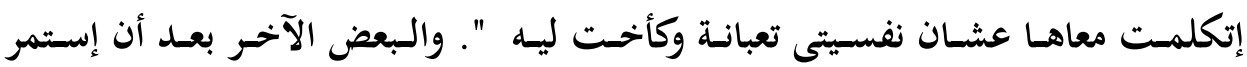


المعتدي فى عنفه الجنسي تجاههن قررن أبلاغ أسرهم ، ولكن غالبا ما كان رد الفعل الهـان

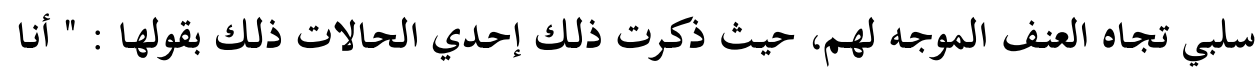

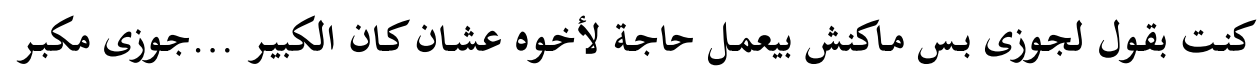

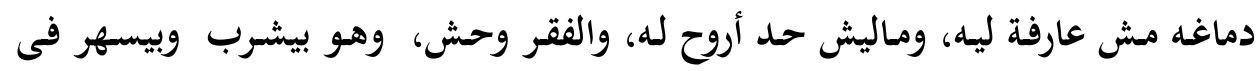

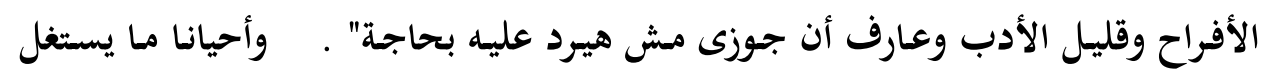

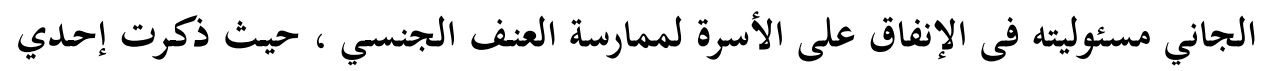

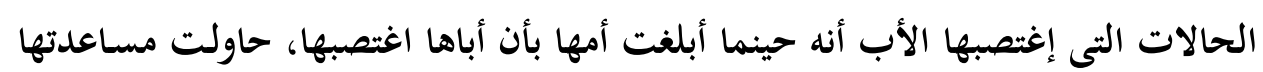

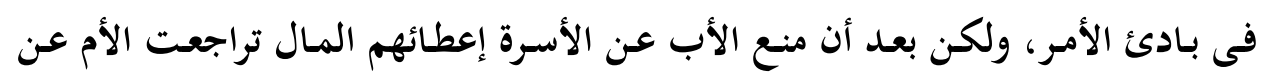

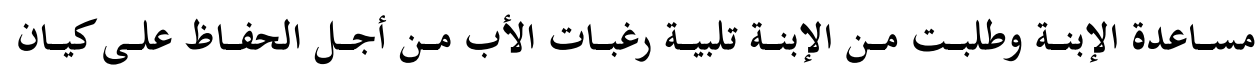

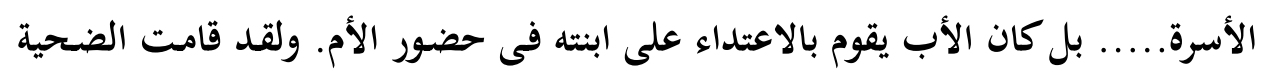

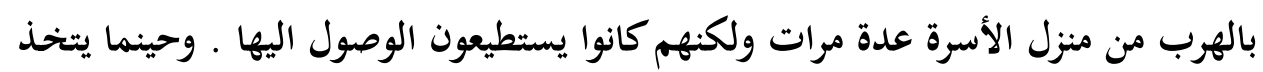

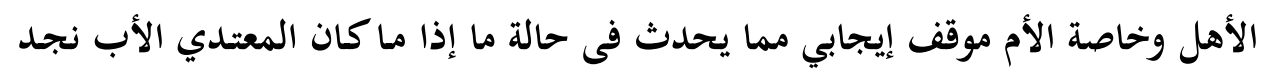

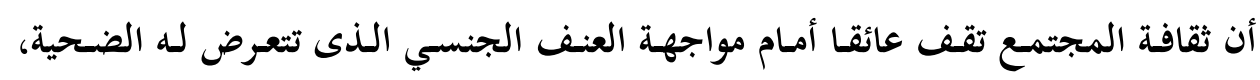

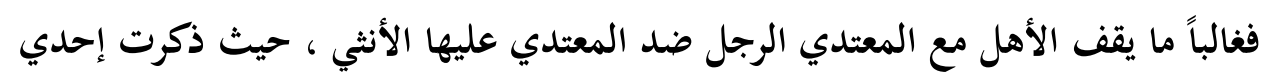

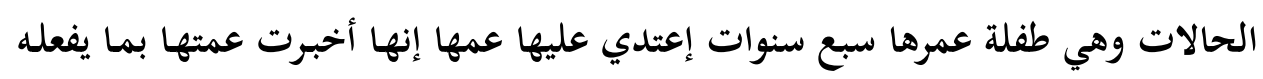

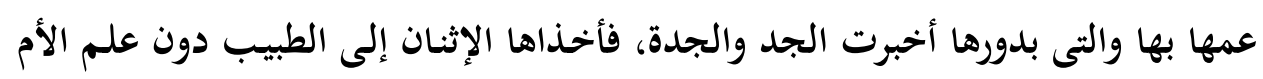

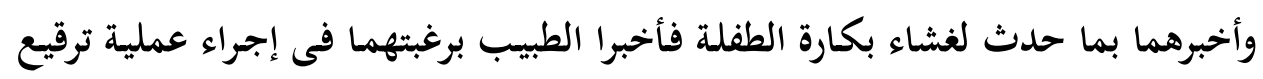

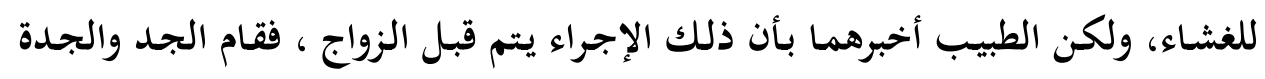

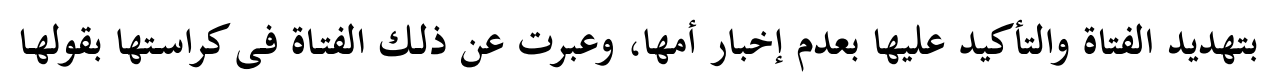

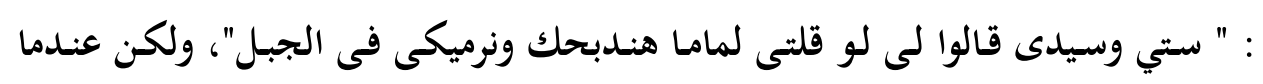

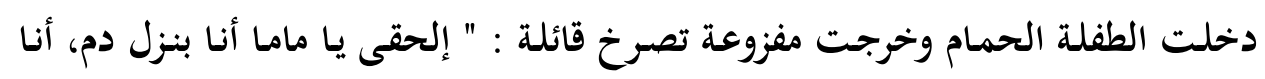

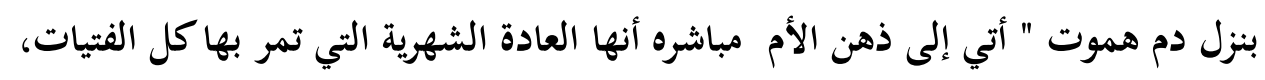

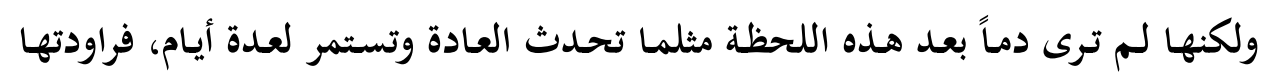


الثـكوك بـأن هنـاك مكروهـا مـا أصـاب ابنتها، فقـررت أخـذها للطبيبـة لكى تتأكـد مـن سلامتها، واندهشت حينها من رفض الأب والأسرة بإصرار مبالغ فيه ذهابها للطبيبة .

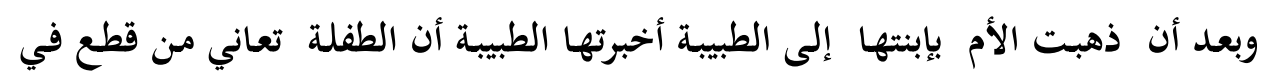
غشاء البكارة، فتحدثت إلى إبنتها ووعدتها بأنها لن تؤذيها وأنها سوف تقف إلى إلى إنى جانبهابها،

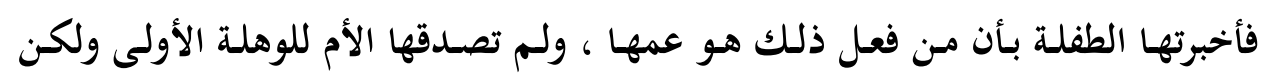

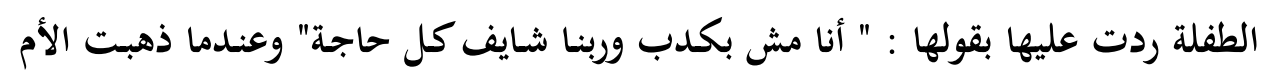

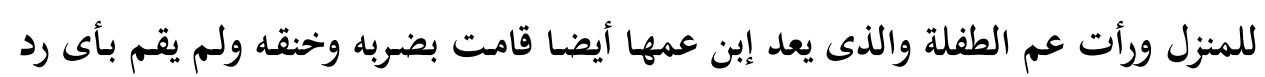

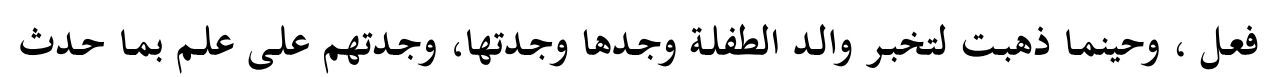

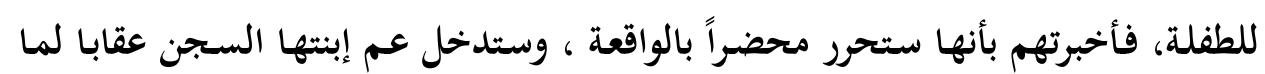

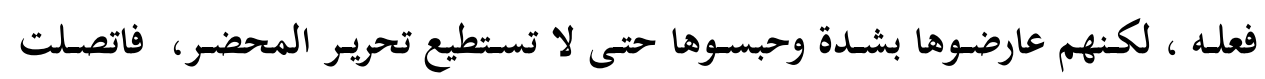

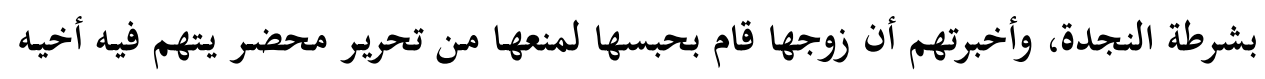

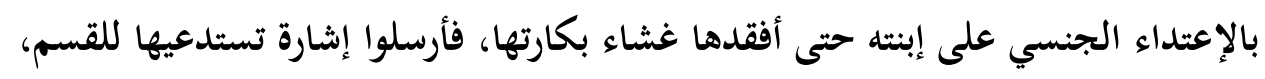

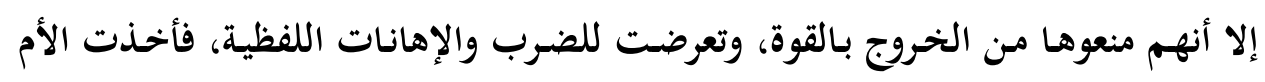

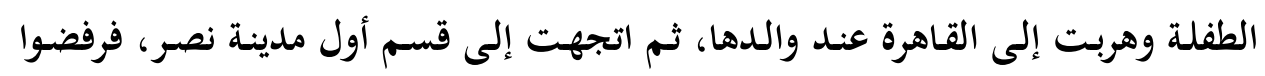

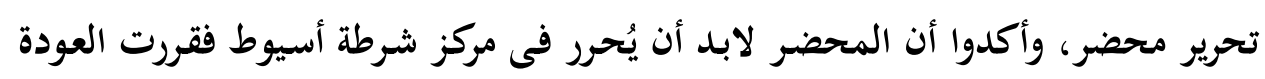

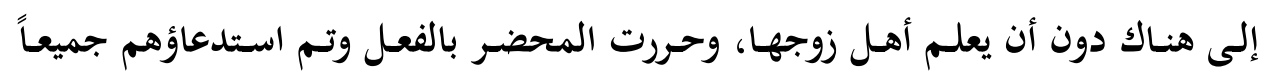
ولكنهم نفوا. ففي نظر ثقافة المجتمع وخاصة فى صعيد مصر أن ما فعلته والدة الفتاة "

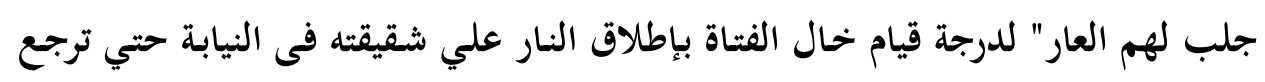

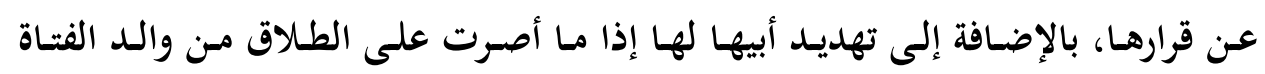

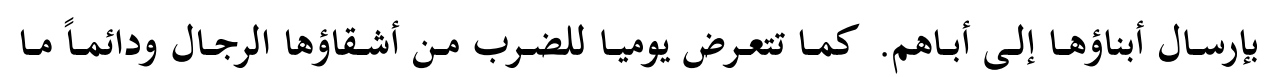

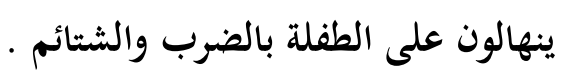

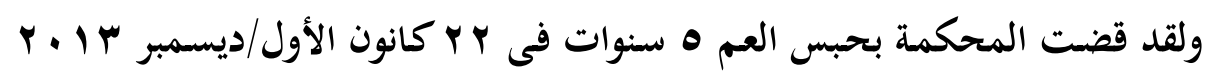

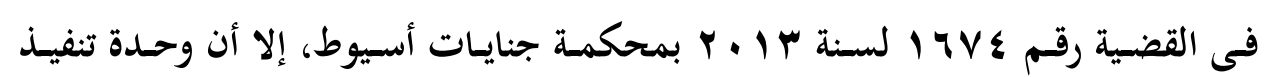


الأحكام لم تستطع القبض عليه حتى الآن ومازال حرا طليقا. وذكرت المحامية انتصار السعيد، مديرة مركز القاهرة للتنمية وحقوق الإنسان، الذي تبنى قضية الطفلة الطية أن الحكم

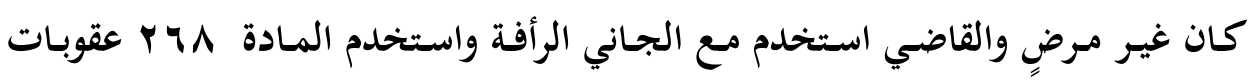
بدلا من المادة 9 ج Y عقوبات التى حددت عقوبة هيك العرض بالسجن المؤبد اذا كان

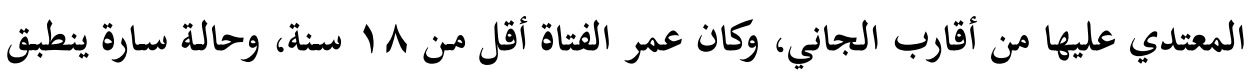
عليها الشرطان.

ع - الأسباب والدوافع الكامنة وراء ممارسة العنف الجنسي ضد المحارم من وجهة نظر الحالات:

- المشاكل الزوجية الكثيرة والتى يتبعها عقاب الزوجة لزوجها من حقه الشرعي، وتعبر

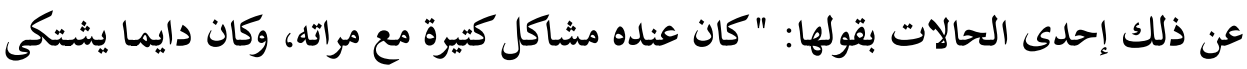

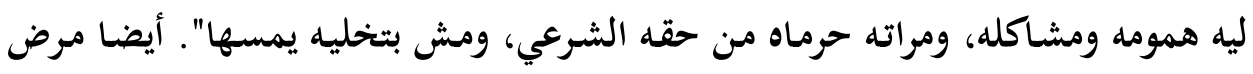

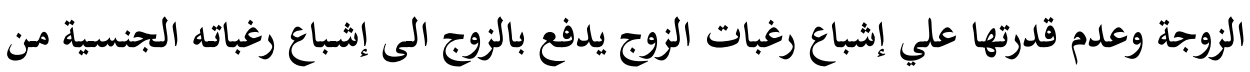
خلال محارمه وخاصة فى ظل ظروف الفقر وضعف المنظومة الدينية والأخلاقية ـ وتعبر

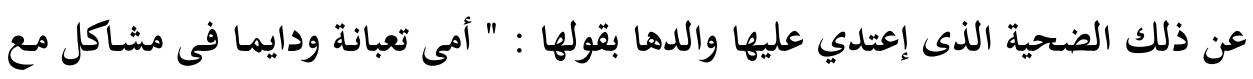
أبويا، والسبب اللى خلاه يعمل كده قلة دينه والفقر اللى أحنا فيه".

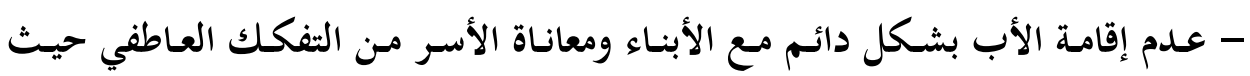

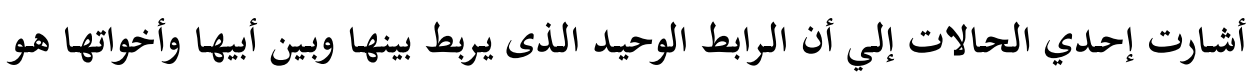
المال فقط . التصال - قد يكون للشخص المعتدى وأسرته بأكملها تاريخ فى الاعتداء الجنسي حيث ذكرت

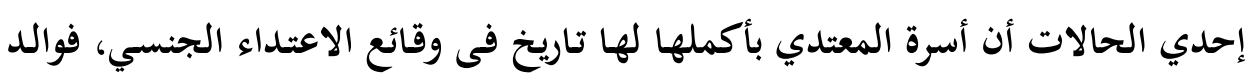

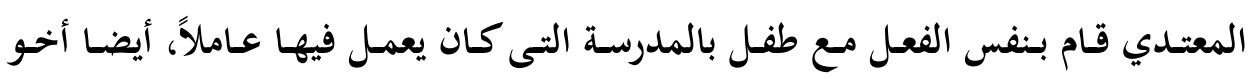
المعتدي قام بنفس الفعل مع طفلة غريبة عن الأسرة. 
- الاعتياد على مشاهدة الأفلام الإباحية، والرغبة فى محاكاة ما نشـاهده. وتعبر عن

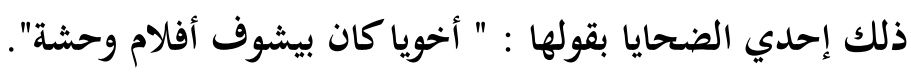
- تعاطي المواد المخدرة كالحشيش والترامادول وغيره. هـ الآثار الاجتماعية والنفسية المترتبة على ممارسة العنف الجنسي:

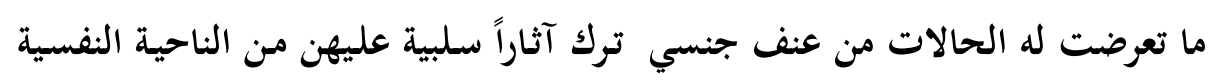

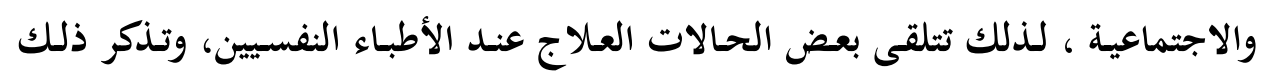

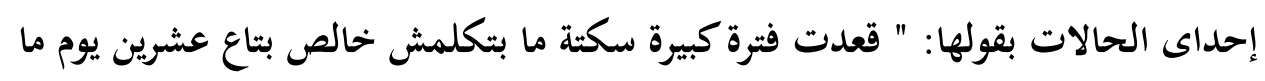

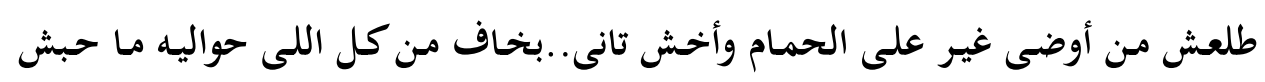

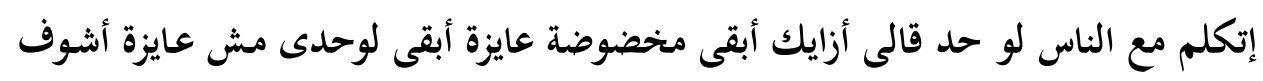

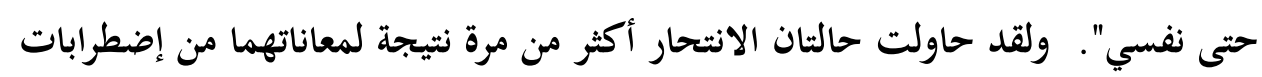

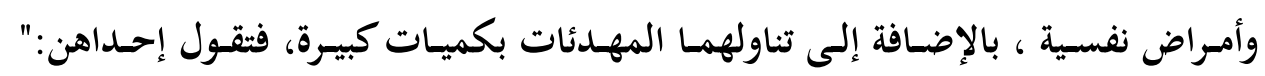
حاولت الانتحار أكتر من مرة، عورت نفسي، وجبت سم وحاولت أثربه ، ومنعت الأكل أسبوع أو عشر أيام وشربت برشام كنت يأسه من الحياة".

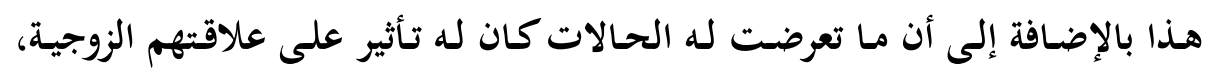

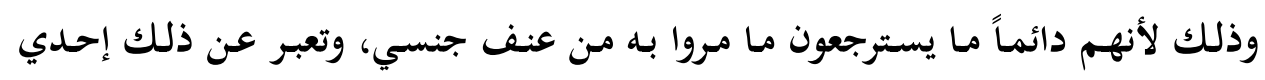

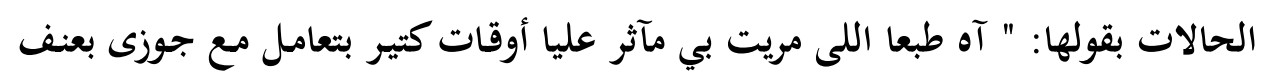

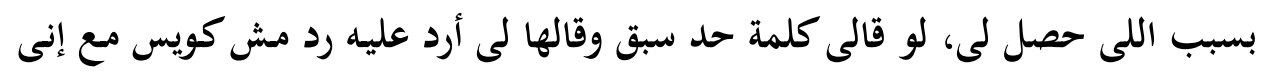

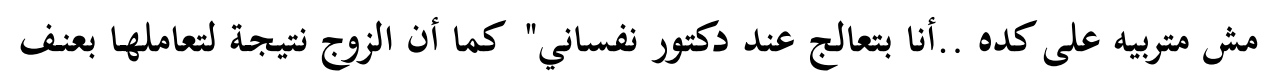

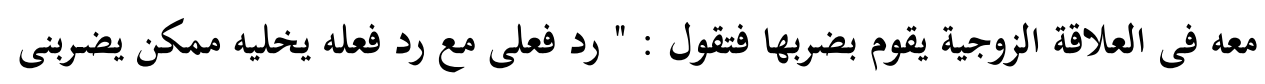

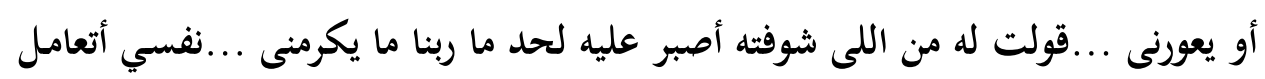

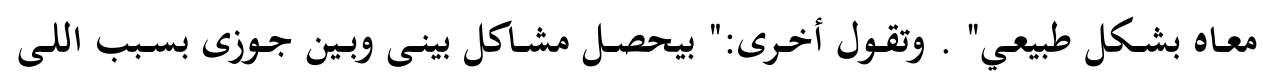

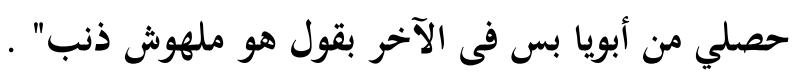




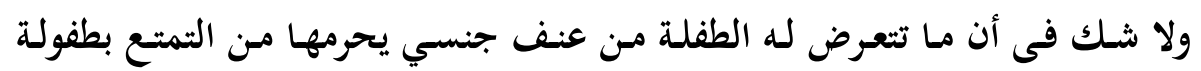

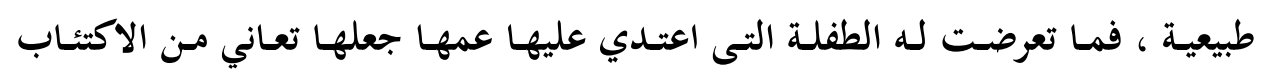

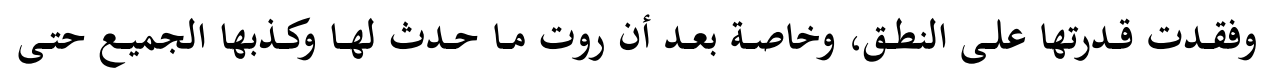

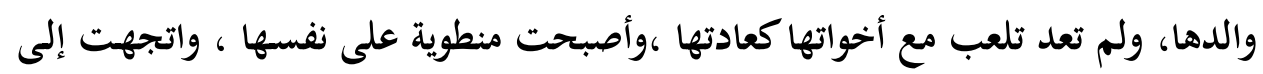

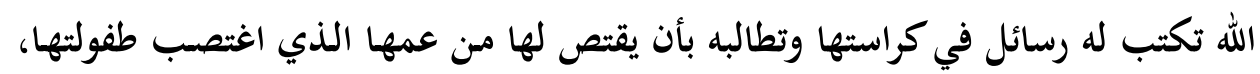

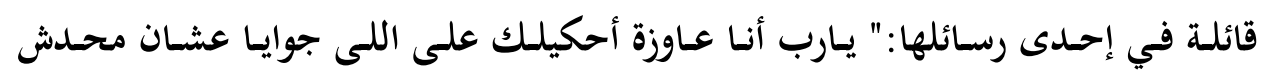

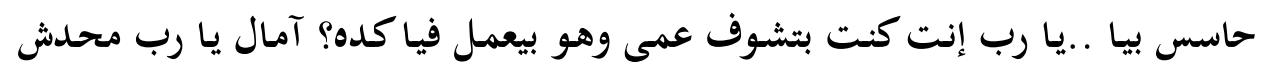

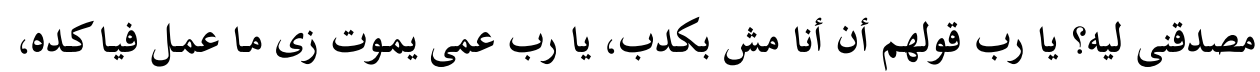

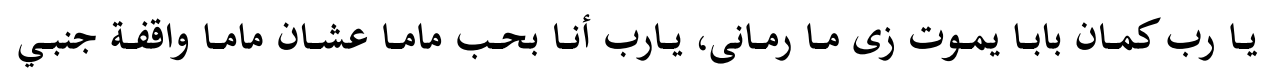

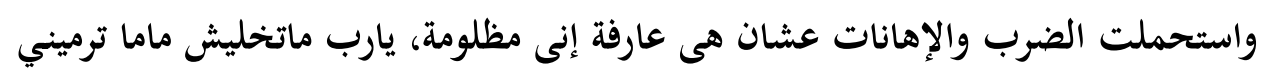

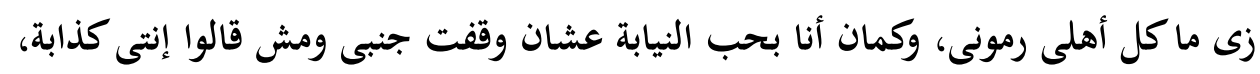

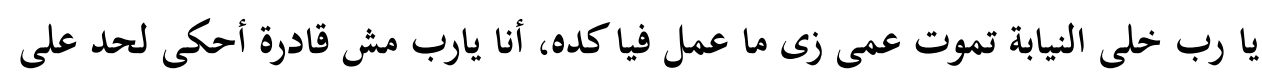

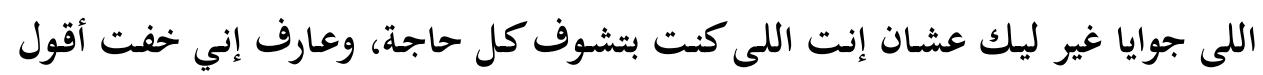

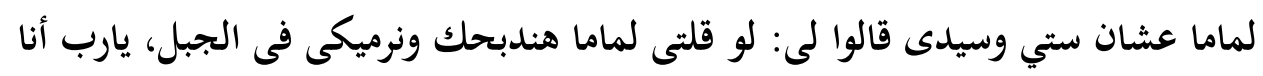

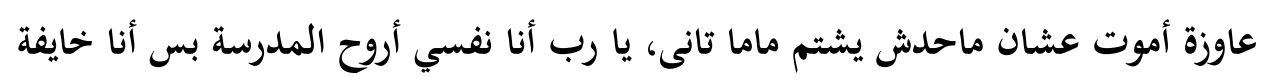

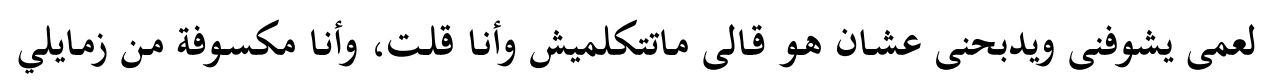
ليكونوا عرفوا" (56).

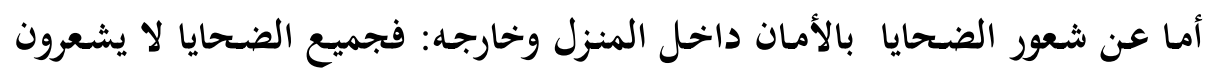

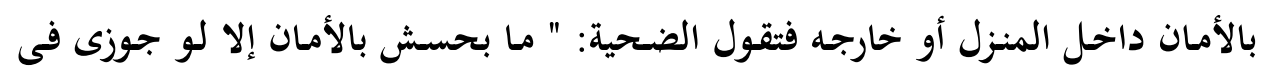

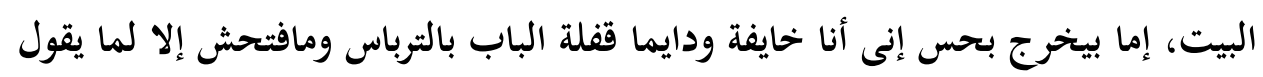

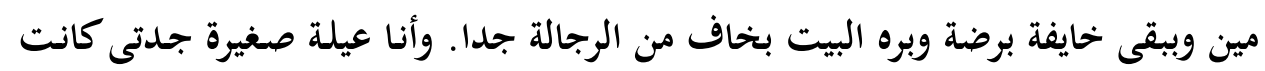

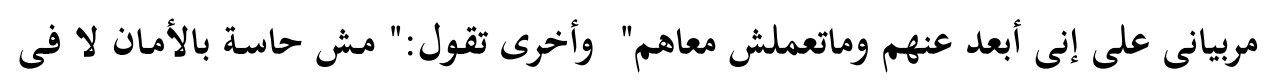




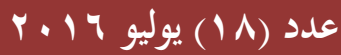

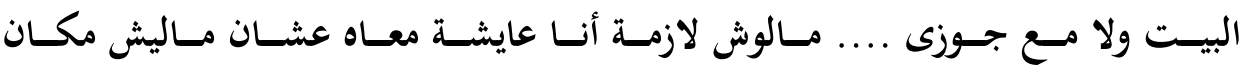

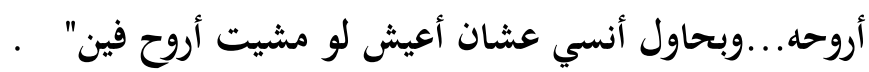
ب- تحليل ننائج دليل مقابلة العاملين الذين يتعاملون مع ضحائ لإيا العنف الجنسي: 1- أشكال العنف الجنسي الموجهه للنساء :

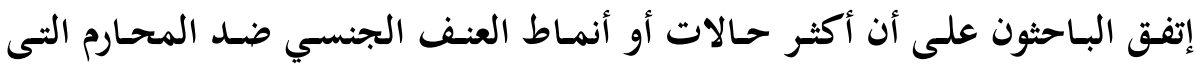

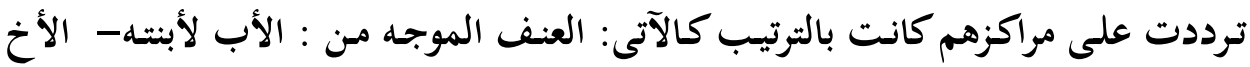

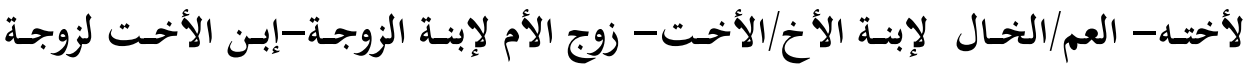

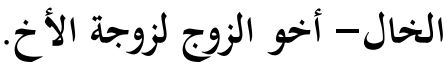

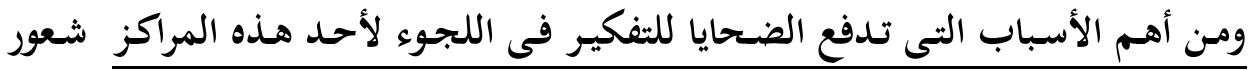

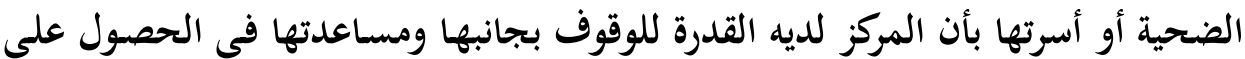
حقها (المساعدة القانونية وطلب التقاضى)، كذلك البحث عن المساعداعدة النفسية،

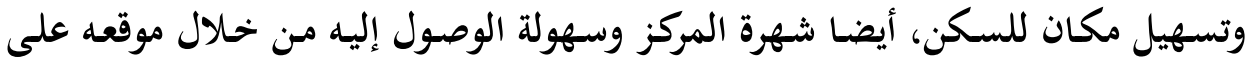

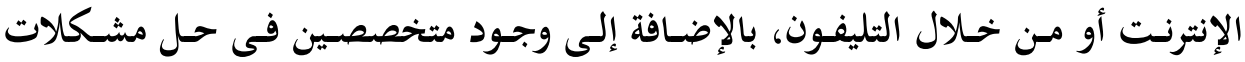
المرأة، أيضا طلب الحماية والمساندة لتحقيق العدالة والإنصاف.

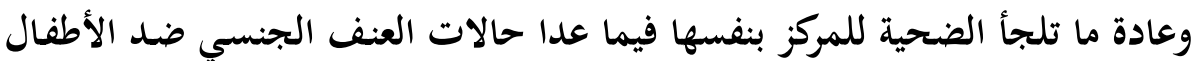

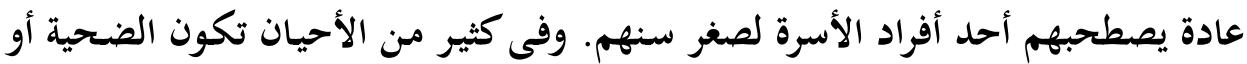

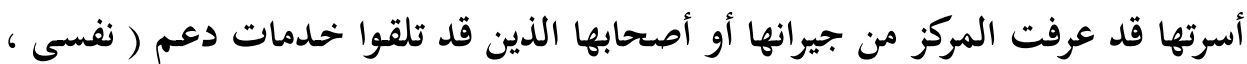
قانونى ، اجتماعى ) من المؤسسة.

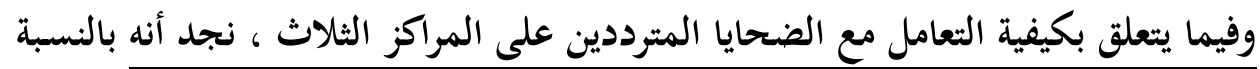

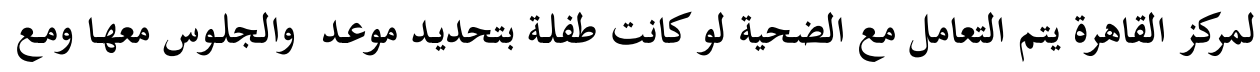

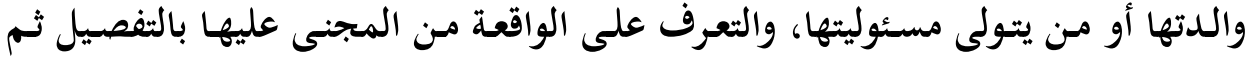

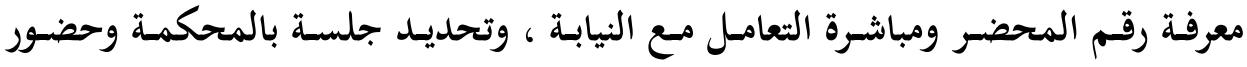

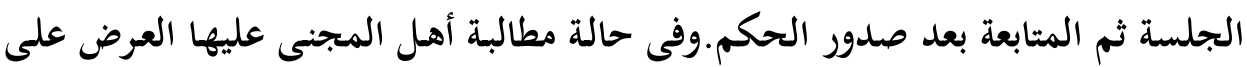


طبيب نفسى لعمل الدعم النفسى يتحدد موعد مع الطبيب والذهاب معها أول مرة ثم

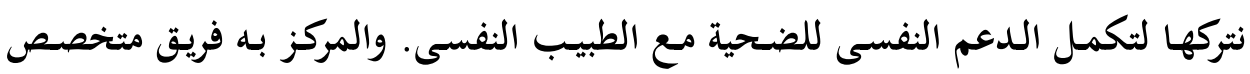

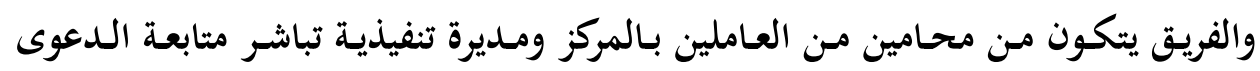

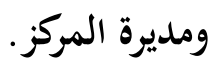

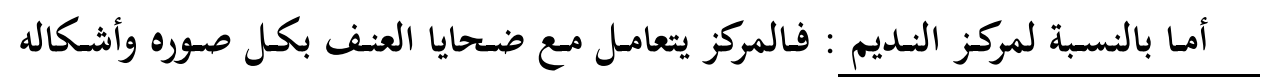

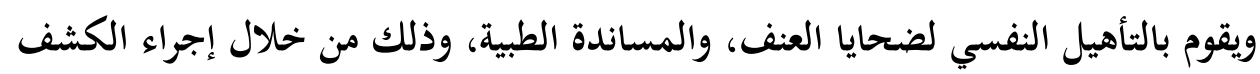

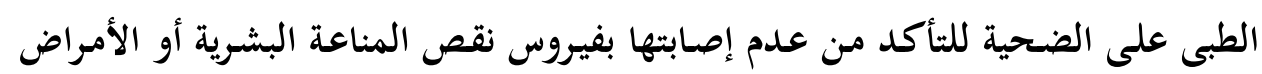

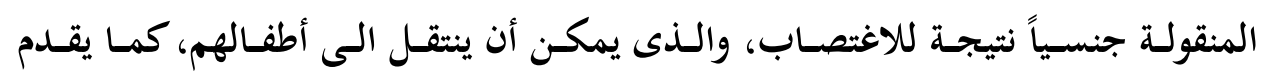
الإستشارات القانونية للضحايا حيث يوجد بالمركز أطباء وأخصائيون نفسيون.

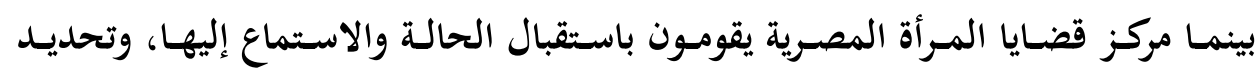

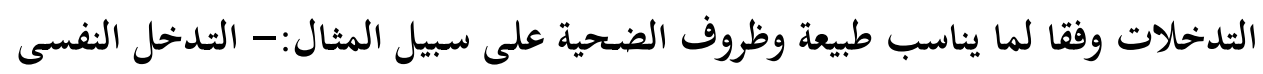

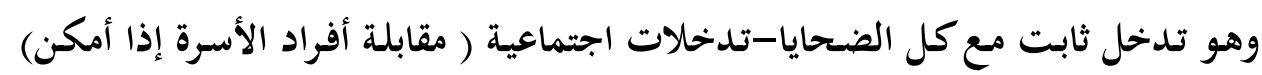

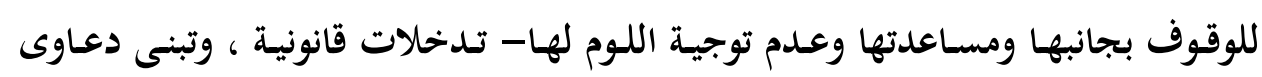

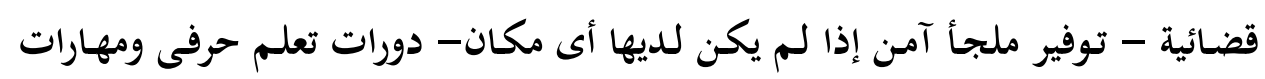

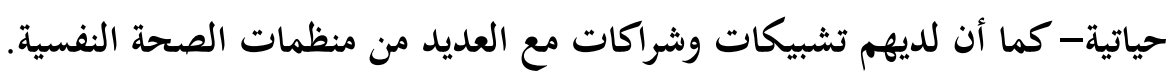

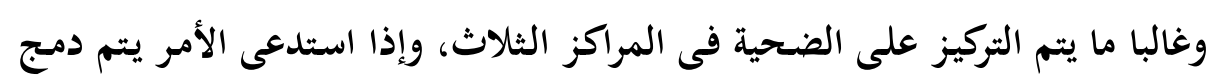

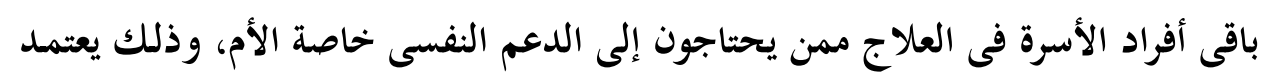

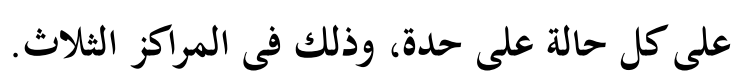

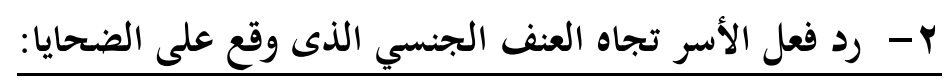

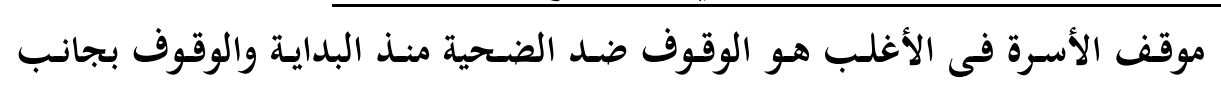

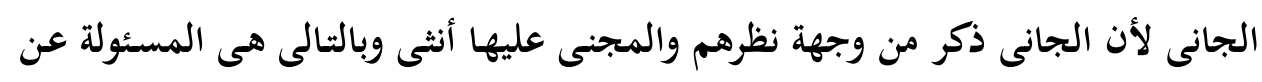

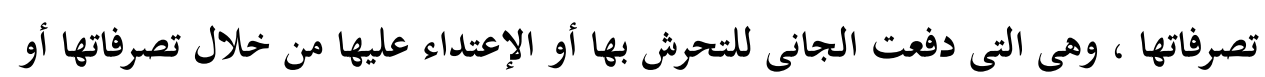

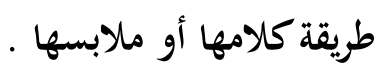


ويري البعض الآخر أنه لا توجد قاعدة فهناك أسر داعمة منذ البداية حتى فى اللجوء

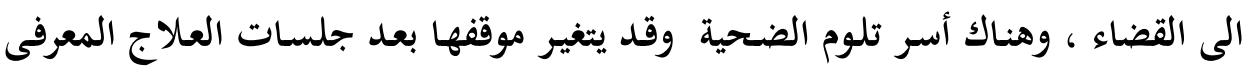

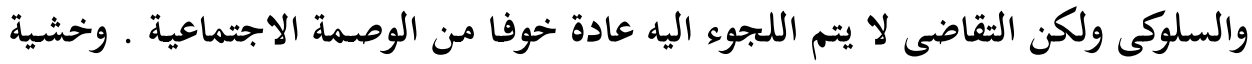
الأسر من الفضحية ، وأيضا لما لهذه القضية من خصوصية كونها تقع داخل الأسر يجعل التعل

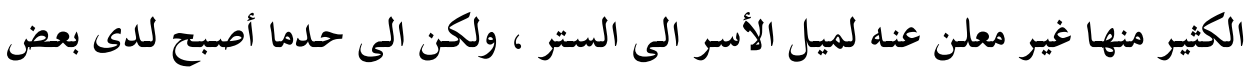
الأسر الوعى فى أن تتخذ بعض الخطوات لحمايه أبنائها.

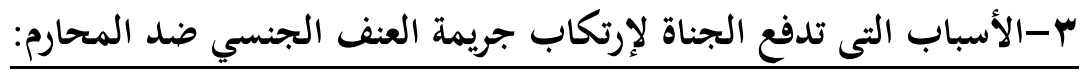
يري الباحثون مـ واقع تعاملهم مع الضحايا أن من أهـم الأسباب التى تدفع الجـاني

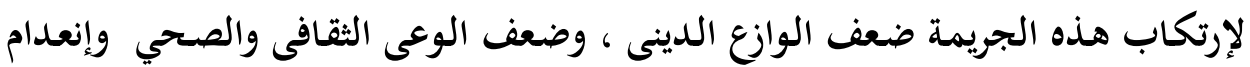

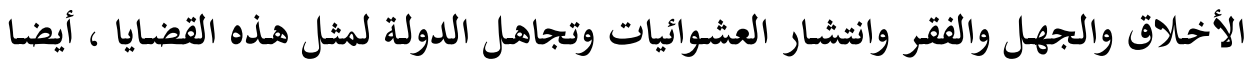

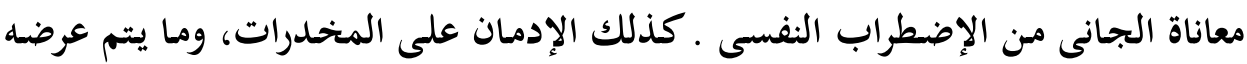
فى وسـائل الإعلام والإتصـال المختلفة مـ مشـاهد جنسية وأفلام إباحية تثير الغرائز،

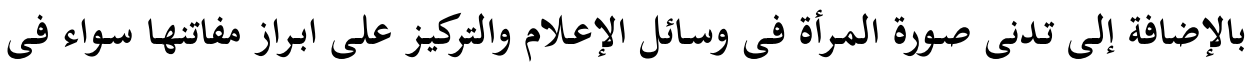

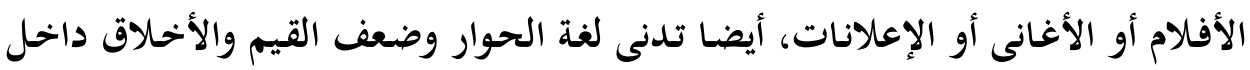

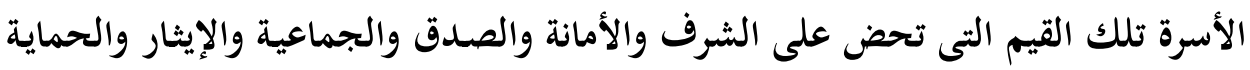

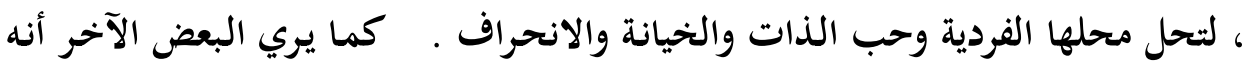

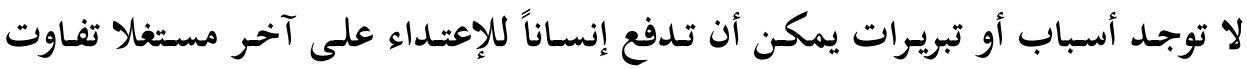

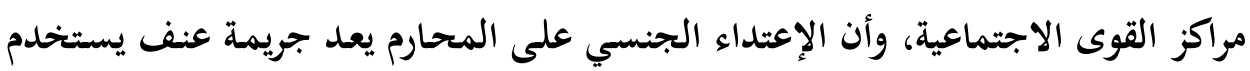
فيها الجنس كأداة.

ويرى العاملين بالمراكز الثلاث أن المشكلة تنتشر بكل الطبقات الاجتماعية الطبقـة

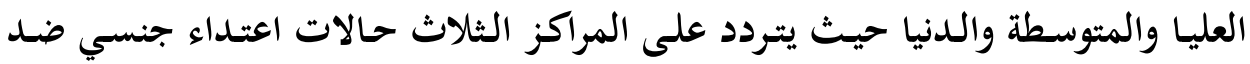

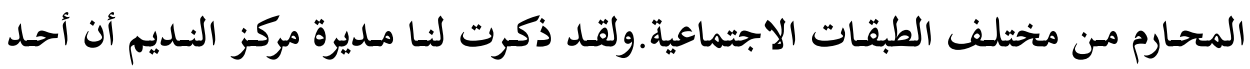
الحالات التى كانت تتردد على المركز كان الأب يشغل وظيفة مرموقة جدا وهو الذى ستى 
كان يقوم بالتحرش بها، ولكن الأفراد المنتمين إلى الطبقة العليا غالبا ما يخحافون على

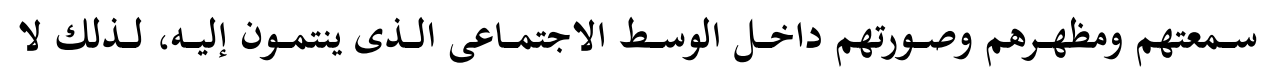

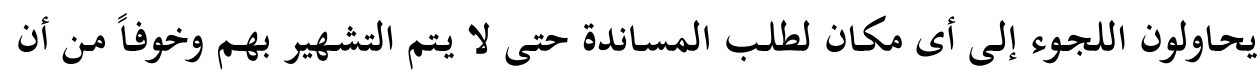
يؤثر ذلك على وضعهم الاجتماعى والاقنصادى. ع -الآثار الاجتماعية والنفسية المترتبة على ممارسة العنف الجنسي:

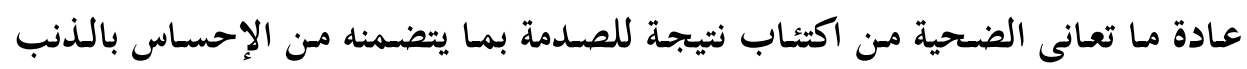

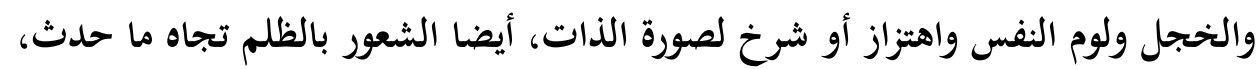

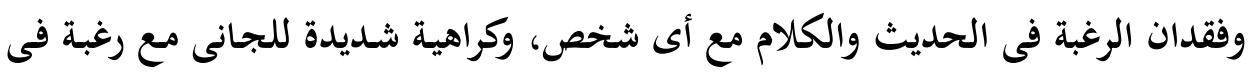
الإنتقام منه وتمنى الموت له ـ وفقدان الرغبة فى الإندماج فى المجتمع. ه- العقبات التى تقف أمام التدخل العلاجى والقضائى للضحايا:

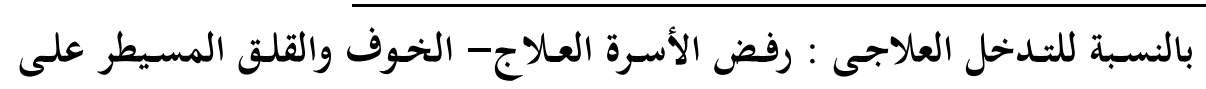
الضحية من أفراد الأسرة ومن المصير المنتظر، ومن لوم المجتمع لها باعتبارها المسئولة

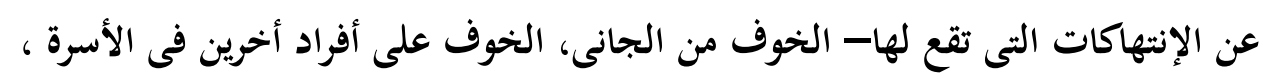

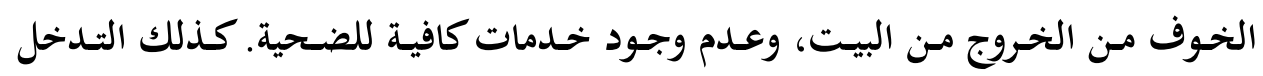

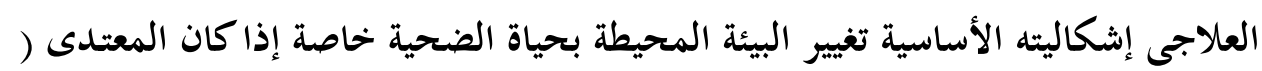

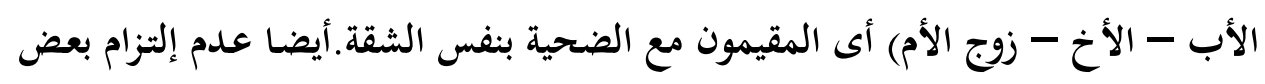

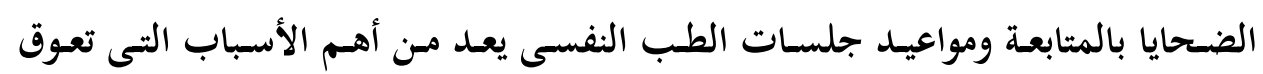
- (20لاج

وبعض الضحايا يستمرون فى التردد على المراكز ولكن الأكثرية ينقطعون وخاصة إذا

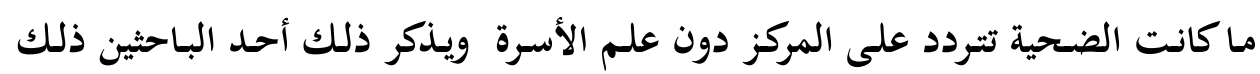

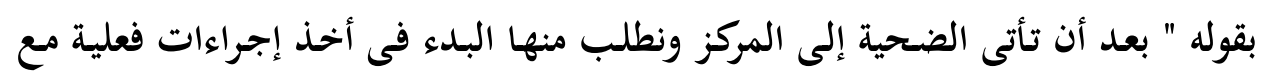
الجانى ، أو عندما نطلب منها التحدث مع أفراد الأسرة ، تشعر بالخوف الشديد، وتشير

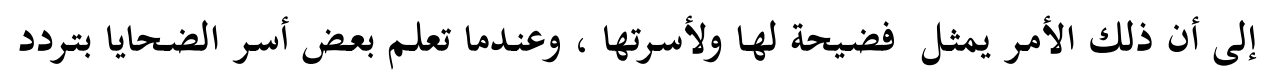


الضحية على المركز تمنعها من الخروج أو الذهاب الى أى مكان" وتقول باحثة أخرى :"

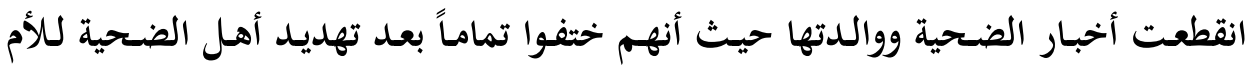
باستمرار بخطف الصغار منها". فالضحايا يريدون أخذ حقهم وفى نفس الوقت يخشون رد الفعل والهجوم عليهم من قبل المجتمع واللوم المحتمل أن يتعرضوا له، لذلك أحيانا تكتفى الضحية بالثدخل النفسى والاجتماعى وبمجرد أن تتعافى تبدأ فى ممارسة حياتها الطبيعية دون تردد وهناك من يشارك فى الفعاليات التى تقوم بها المؤسسة ولدية الرغبة فى التطوع فى هذه الفعاليات. ولكـن بالنسبة للتدخل القضـائى فتتحدد العقبات التى تقف أمـام التدخل القضائى فى بطء إجراءات التقاضى لحين صدور تقرير الطب الشرعى - عدم وجود دليل مادى أو لهات شهود على الواقعة -إخفاء الأسرة وإنكارها للواقعة. إضافة إلى أن هذه الجريمة تقع فى لى سلى النطاق الأسرى وعادة ما ترتبط بالقبلية العائلية لذا تخشى الضحية من وقوع الكثير من الجرائم إذا ما لجأت إلى القضاء. ومن الممكن أن تتراجع الضحية عن الدعوى القضائية

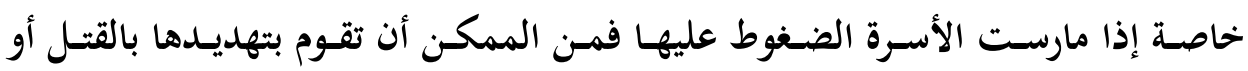

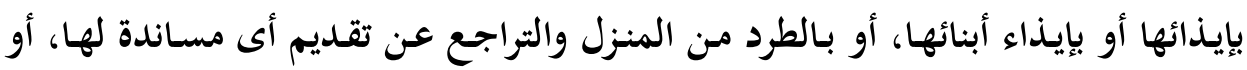
الوقوف ضدها في المحكمة فى مقابل تدعيم الجاني . 7 - موقف القانون المصرى من ضحايا العنف الجنسي ضد المحارم :

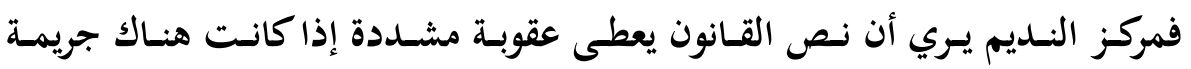

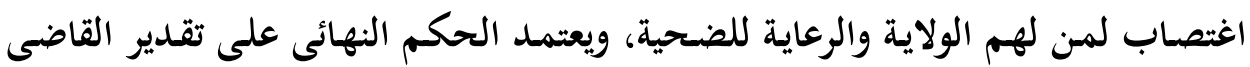

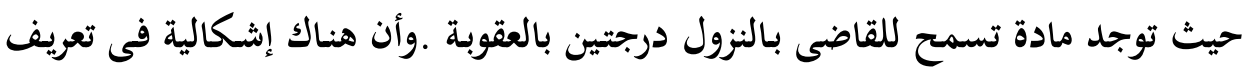
الاغتصاب فى نص القانون حيث لا يعترف بالاغتصاب الشرجى أو الفمي أو بأداة وتقع لـع تلك الجرائم تحت وصف (هتك العرض). ولقد حصل مركز النديم على حكمين كل

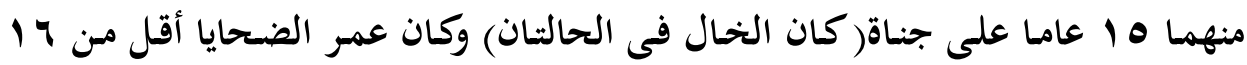
سنة. وحكم بالإعدام على خال ضحية قتلها بعد الإغتصـاب خوفا من إفنضاح جريمته، 
وحفظت مؤخراً قضـية أب إعتدى على إبنته، لأن الطب الشـرعي أثبـت سـلامة غشــاء البكارة، على الرغم من إعتداء الأب عليها .

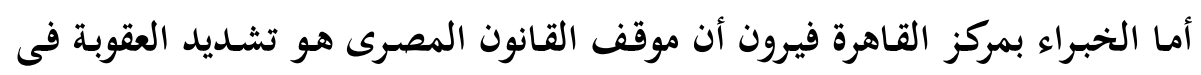

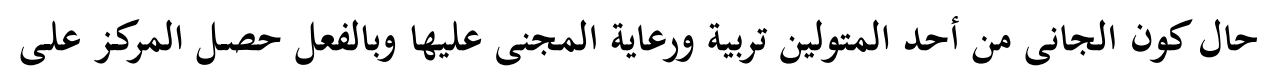

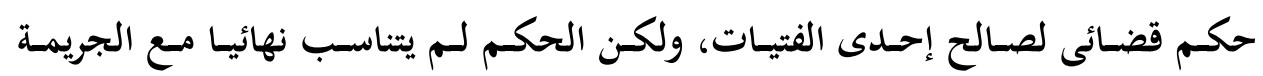
المرتكبة، وبالفعل يحتاج القانون إلى تغليظ العقوبة فى بعض الجرائم .

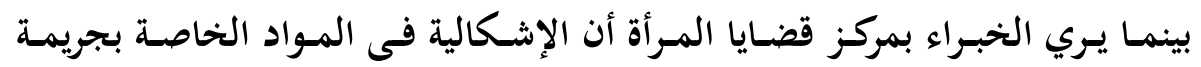

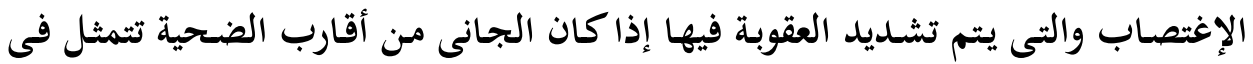
الثبوت والتنفيذ ، إضافة الى سلطة القاضى التقديرية التى قد تعطى الجانى حكما مخففا. ج- نتائج تحليل مضمون حوار الحالات المستضافة في البرامج : 1 البرامج التى تم تحليلها: جدول رقم ( l) - البرامج التي تم الاعتماد عليها فى التحليل:

\begin{tabular}{|c|c|c|c|}
\hline المستضدافة الحالات & السنة & اسم القتاة & اسم البرنامج \\
\hline 1 & $r, 1 Y$ & النهار & صبايا الخيز \\
\hline 1 & $r \cdot 1 r$ & المحور & صبايا \\
\hline$r$ & $r \cdot 1 r$ & القاهرة & أجرأ الكلام \\
\hline 1 & $Y, 1 \varepsilon$ & النهار & صبايا الخيز \\
\hline 1 & $r \cdot 1 \varepsilon$ & أون تي في & ست الحسن \\
\hline$r$ & $r .10$ & العاصمة & عنبر الستات \\
\hline 1 & $r .10$ & النهار & صبايا الخير \\
\hline 1 & $r .10$ & العاصمة & عنبر الستات \\
\hline$r$ & $r .10$ & الحياة & بنات البلا \\
\hline r ا حالة & 9 & 9 & الإجمالي \\
\hline
\end{tabular}

يتبين من الجـدول السـابق أن إجمالى عـدد البرامج التى إعتمـدنا عليها فى تحليل مضمون حوار الضحايا (9 ) برامج ، جميعها على قنوات فضائية ، ومن الملاحظ تزايد إند لئل 
الاهتمام بموضوع العنف الجنسي الموجه للمحارم أو كما هو متدوال فى وسائل الإعلام

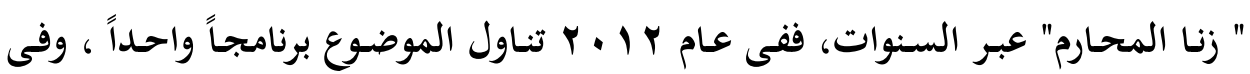

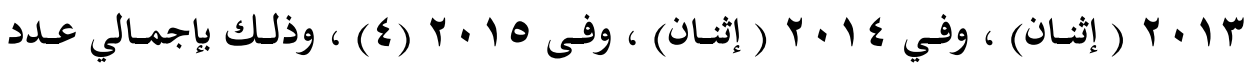

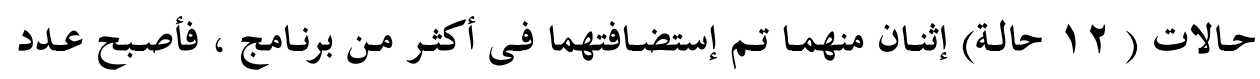
الحالات التي قمنا بتحليلها (• (1) حالات. r-الخصائص الديموجرافية للضحايا والجناة: يتضح من تحليل مضمون حوار الضحايا أن أعمارهم تركزت فى الفئة العمرية الأقل من

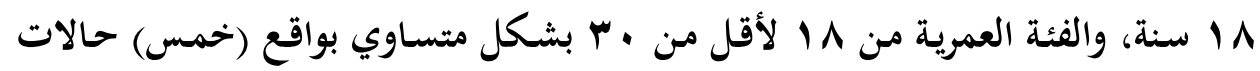

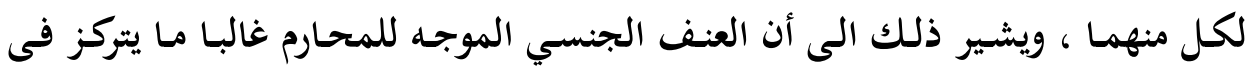

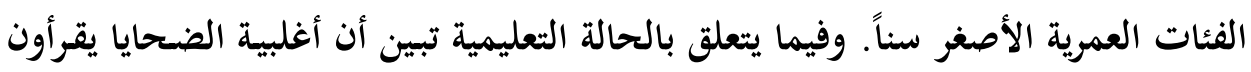
ويكتبون بواقع (خمس) حالات ، يليها الأميون والحاصلين على الإعدادية بواقع ( حالة

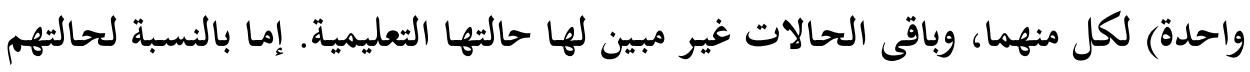

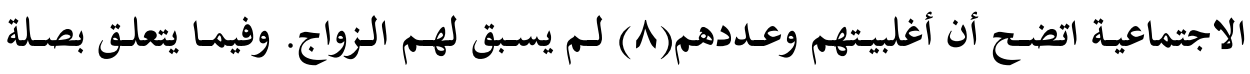

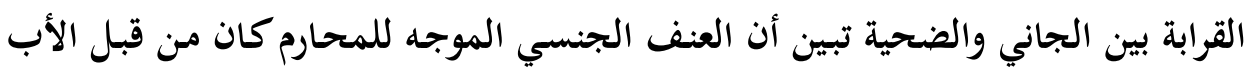

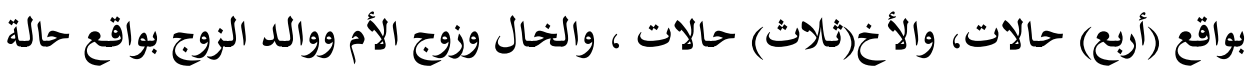

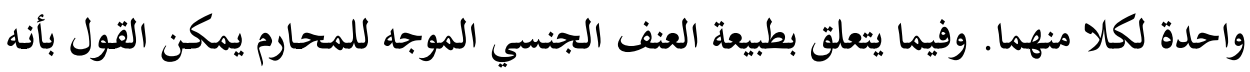

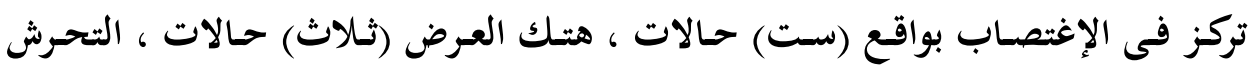

$$
\text { الجنسي (حالة واحدة). }
$$

وتبين من تحليل مضمون حوار الضحايا أن الجناة تتركز أعمارهم فى الفئة العمرية

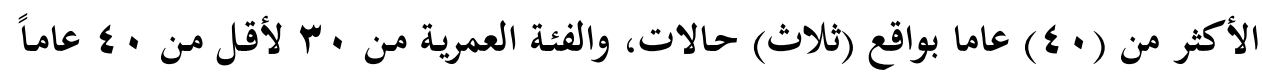

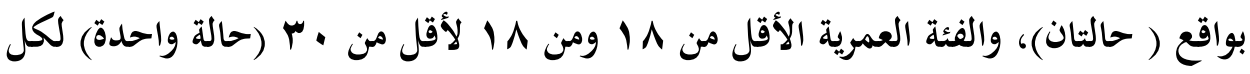
منهما ، وباقى الحالات غير مبينة. كما تبين من التحليل تركز مهن الجناة في الأعمال

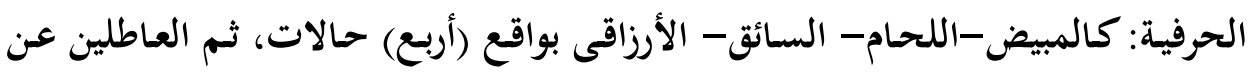


العمل بواقع (ثلاث) حالات، والطلاب بواقع ( حالة واحدة) ، والباقي غير مبين.أما فيما

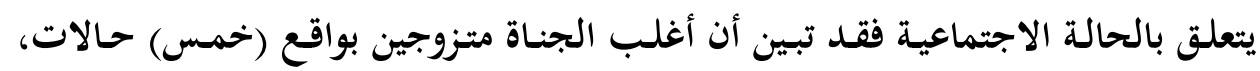
يليها من لم يسبق لهم الزواج بواقع ( أربع) حالات ثم الأرمل ( حالة واحدة) .

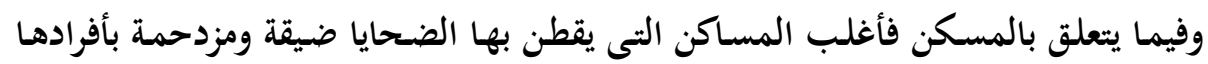

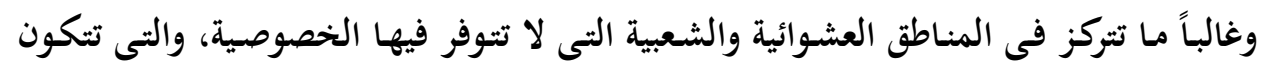

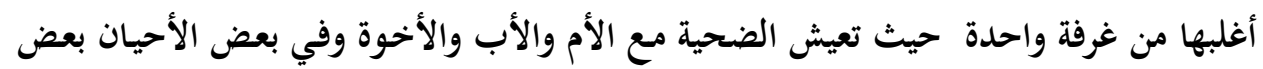

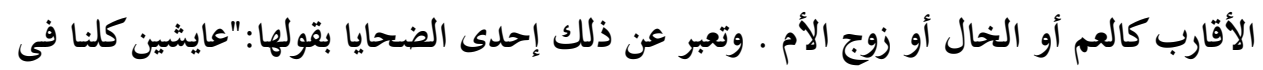

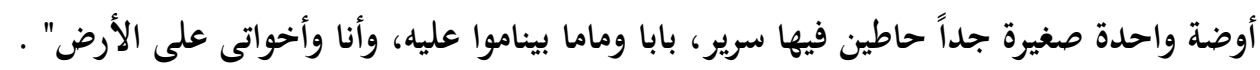

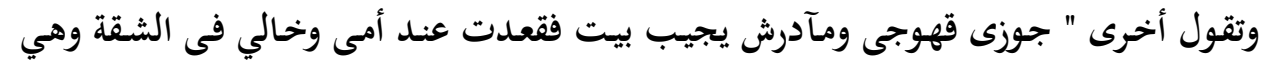

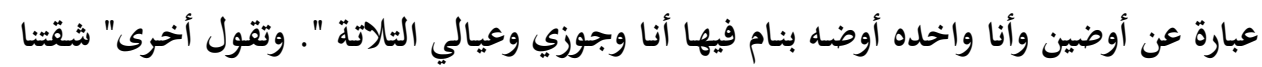

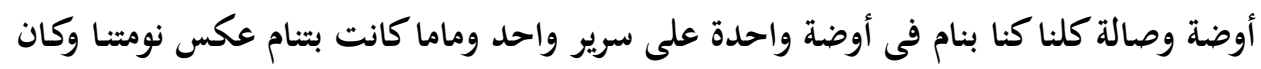

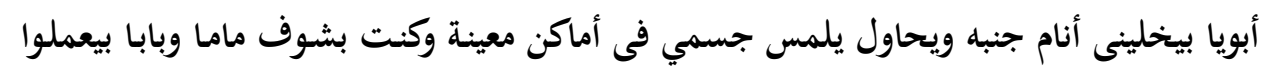

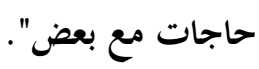

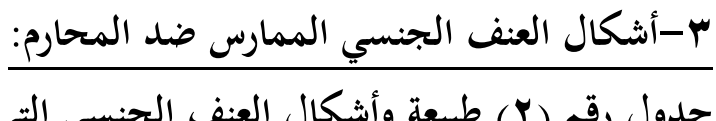

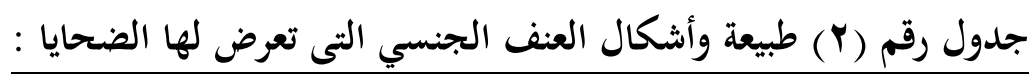

\begin{tabular}{|c|c|c|}
\hline طبيعتـ & نمط العنف الموجه & البرنامج \\
\hline تحرش & الأب ـالأبنة & صبايا الخير-قناة \\
\hline هتك عرض & الأخ -الأخت & صبايا_ قناة المحور \\
\hline اغتصاب & ـالأخت & أجرأ كلام- قتاة \\
\hline |غتصاب & الأب ـالأبنة & أجرأ كلام- قتاة \\
\hline اغتصاب & الأخ-الأخت & صبايا الخير- قناة \\
\hline اغتصاب & زوج الأم-أبنة الزوجة & ست الحس- أون تي \\
\hline
\end{tabular}




\begin{tabular}{|c|c|c|}
\hline تحرش & والد الزوج-زوجة & عنبر الستات - العمةة \\
\hline اغتصاب & الأب- الأبنة & صبايا الخير- قناة \\
\hline اغتصاب & الخال-إبنة الأخت & عنبر الستات- \\
\hline هتك عرض & الأبـ الأبنة & بنات البلد_قناة \\
\hline
\end{tabular}

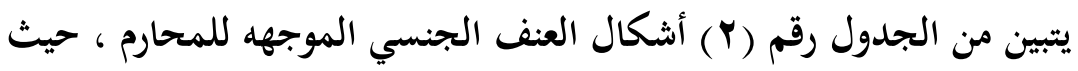

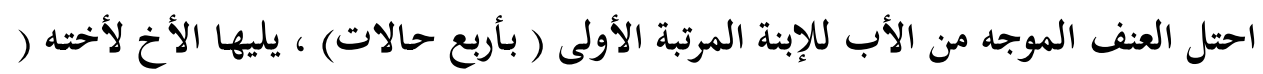

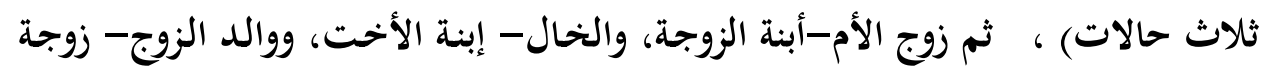

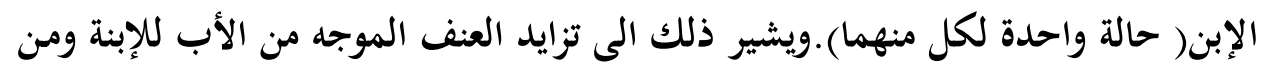
الأخ للأخت .وتذكر الحالات المواقف التى تعرضن لها كالتالى:

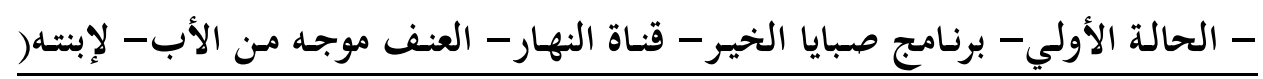

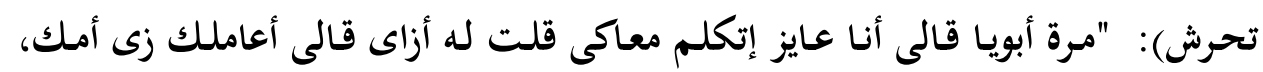

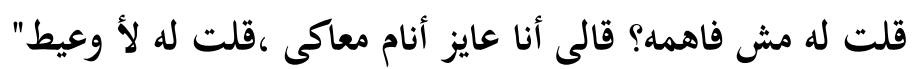

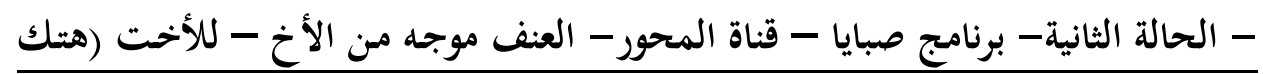

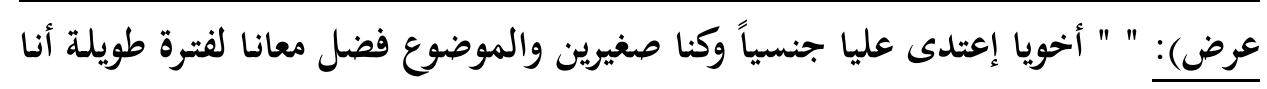
وأختى وبنت عمى، ولكن لما كبرنا إبتديت أقول ده ما ينفعش، ولما كلمته قال لي أحنا أخوات ومش مشكلة وبندارى على بعض، ماما مشغولة فى البيت وبابا بره فى الشغل ومفيش حد شيفنا".

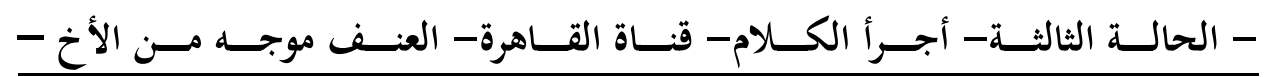

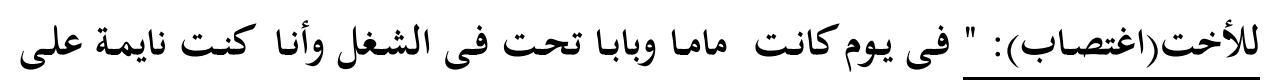

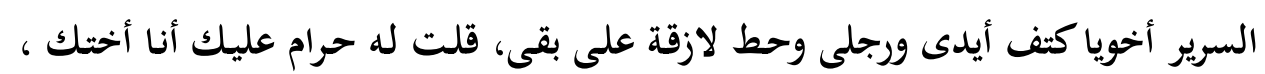


قلعنى الهدوم وعمل اللى هو عايزه، وبعد مـا عمل كحدة قالي لو مامـا وبابا عرفو مش هيحصل كويس".

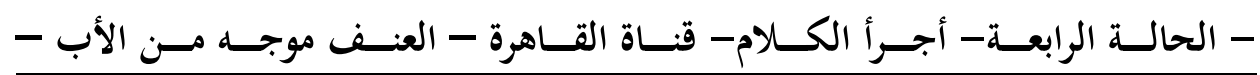

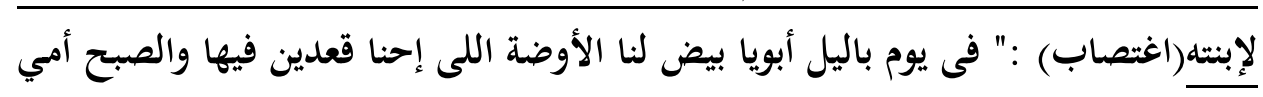

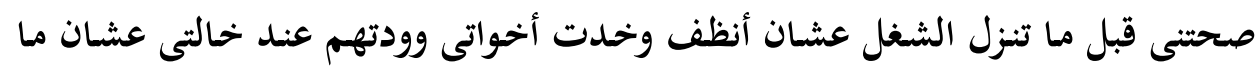

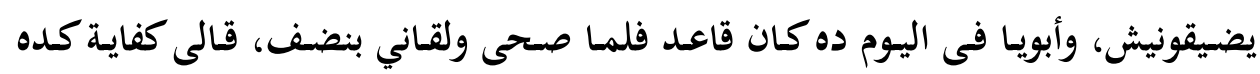

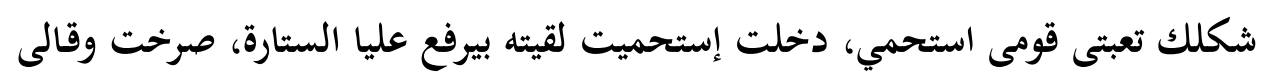

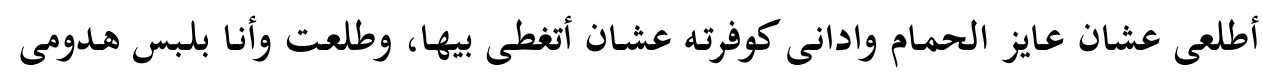

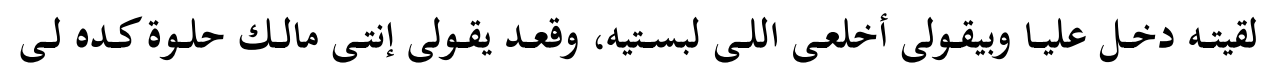

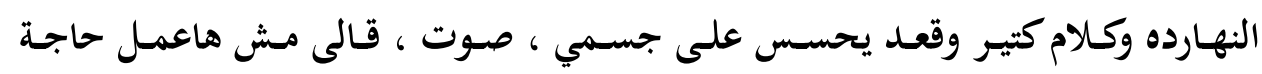

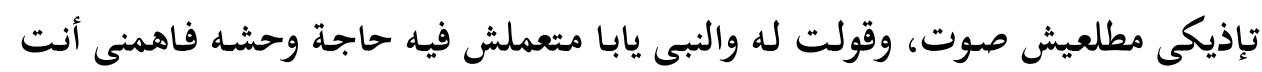

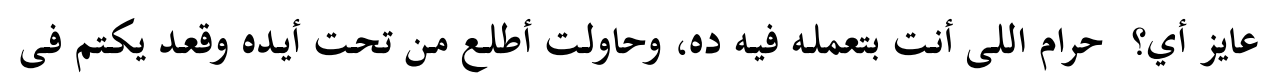

$$
\text { صوتى ويضربنى على راسي جامد " }
$$

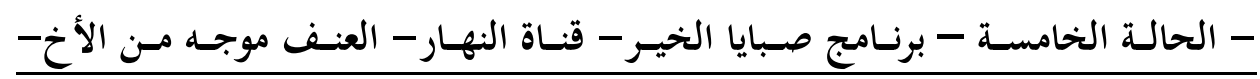

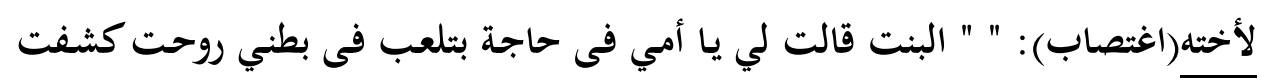

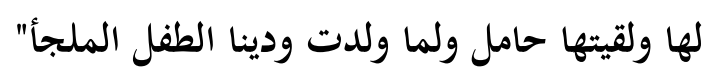
- الحالة السادسة-برنامج ست الحسن- قناة أون تي في- العنف موجه من زوج الأم-

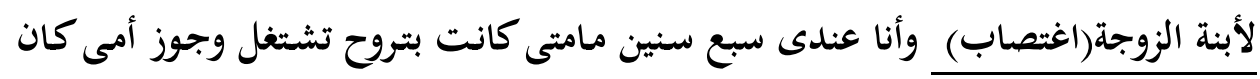

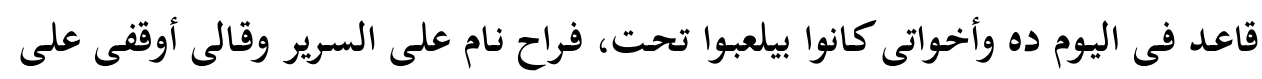

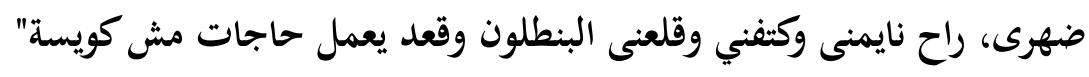

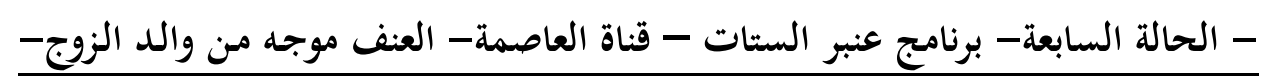

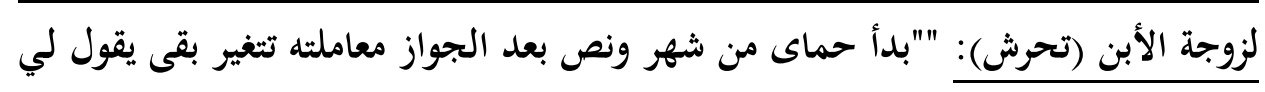

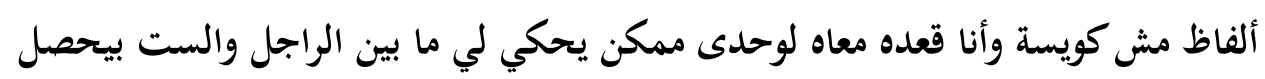




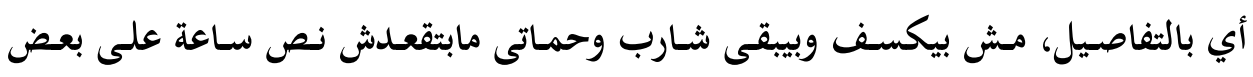

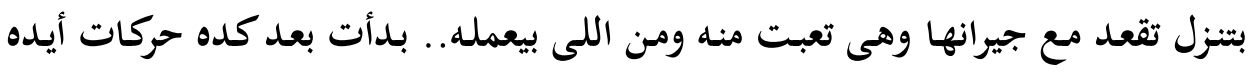

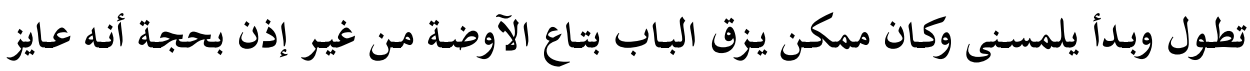
حاجة من على التسريحة". - الحالة الثامنـة - برنـامج صبايا الخير - قنـاة النهار - العنف موجسه مـ الأب لإبنتـه

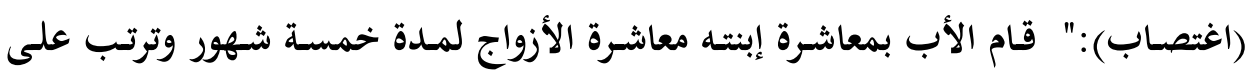
ذلك أن الفتـاة حملـت سفاحا مـ أباهـا ، وعندما ذهبـت الفتـاة للكشـف على نفسـهـا

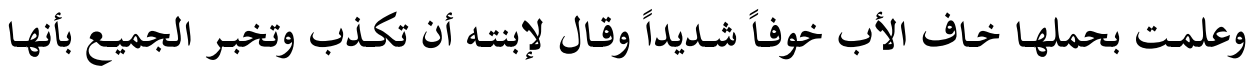
حملت سفاحاً من شخص آخر ولقد ذكرت ذلك بقولها : " روحت كشفت عند الدكتور ولقيت نفسي حامل فى تلات شهور قولت له أتخض، وقالى قولى حد من بره هو الكو اللى

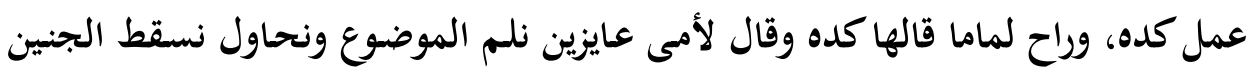

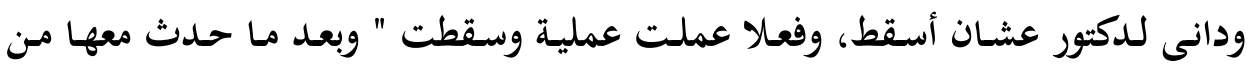

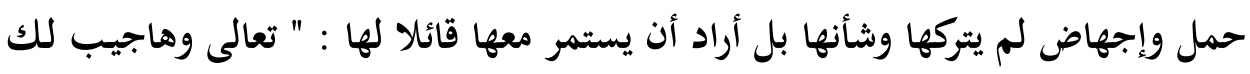
شريط منع حمل".

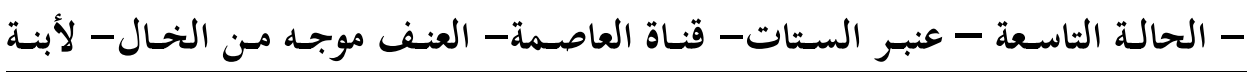

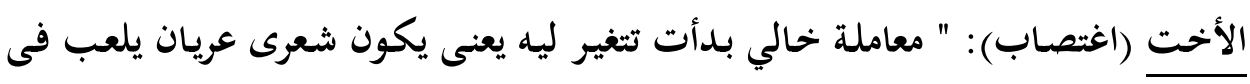

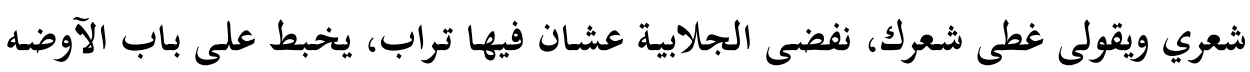

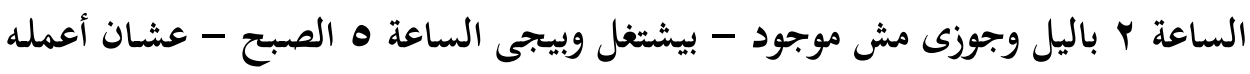

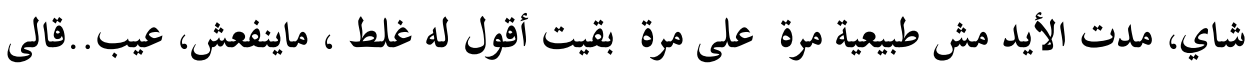

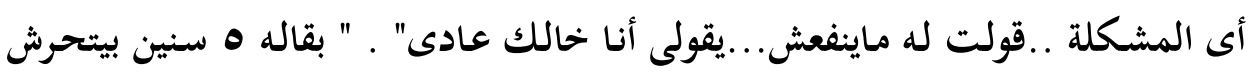
بيه وأخر مره إغتصبنى .. كان فى الحمام قال لي هاتى البشكير وإعتدى عليا إعتداء

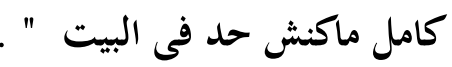


- الحالـة العاشـرة- بنـات البلـد-قنـاة الحيـاة ب - العنـف موجـه مـن الأب لإبنتسه(هتك

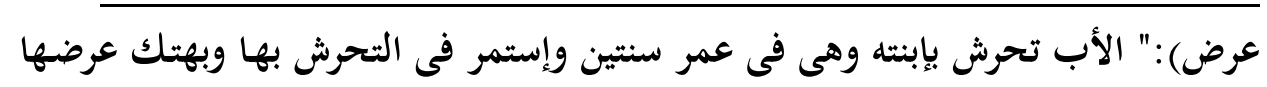
حتى بلغت سبعة عشر عاما، وتذكر المعتدى عليها بعض الوقائع التى مازالت تؤثر فيها

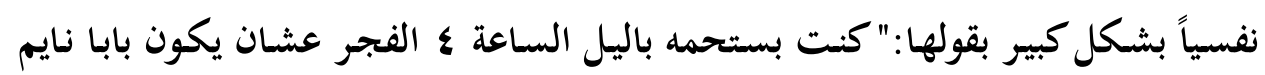

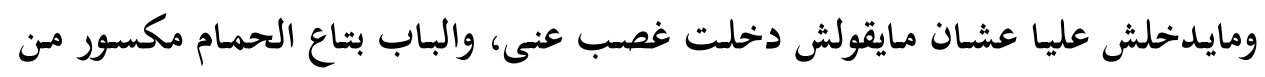

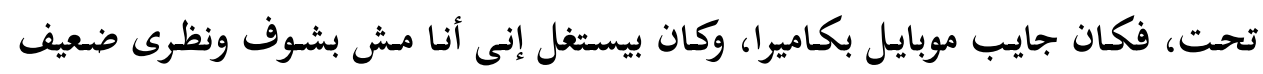
وكان بينام على الأرض وبيصورنى وأنا بستحمه، ومره كنا قاعدين فمسكنى موبايله، وأنا بتفرج على الصسور لقيـت تلات فيديوهات لوحـدة عريانة بتستحمه، ولمـا دققت فيها لقيت نفسي، بعدها بيومين دخلت أستحمى وماقلعتش اللانسز ، لقيته مد أيده من فتحة

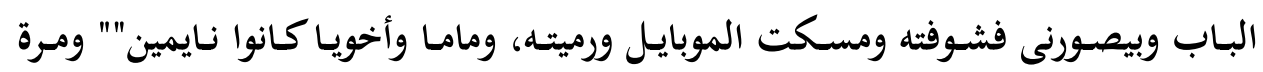

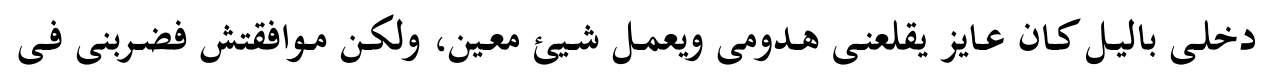

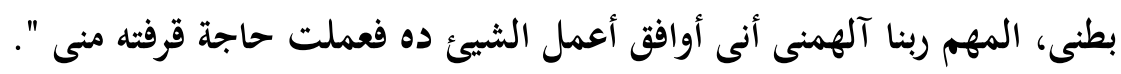

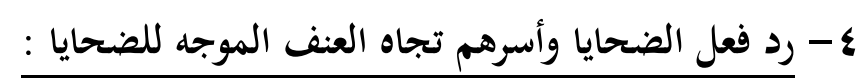

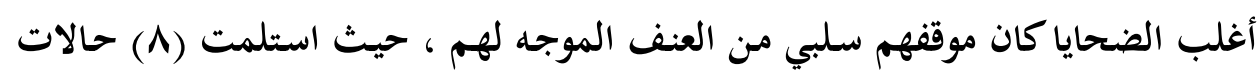
للعنف الممارس ضدهن ، وذلك بسبب ما تعرضن له من إيذاء نفسي من خلال التهديد لهن بالضرب أو القتل أو الإيذاء البدني من قبل المعتدى الذى تمثل فى الضرب المب المبرح

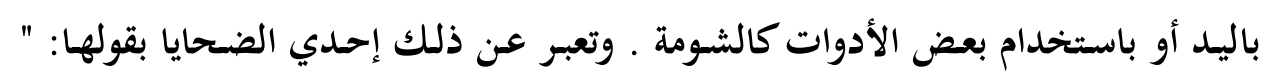

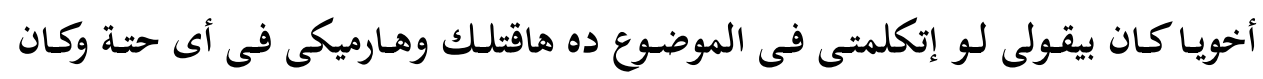
بيمسك خرطوم ويضربنى". وتقول أخري :" إستسلمت للأب لأنه كان يقوم بتهديدي

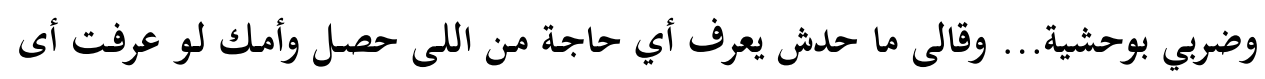

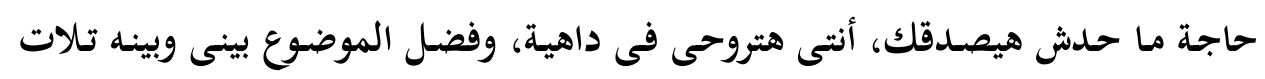

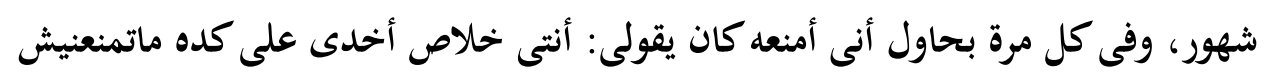

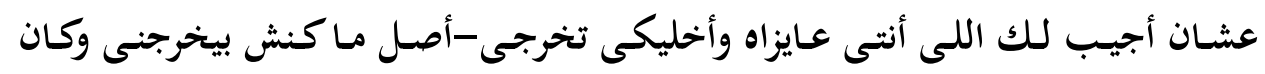




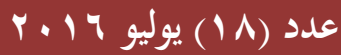

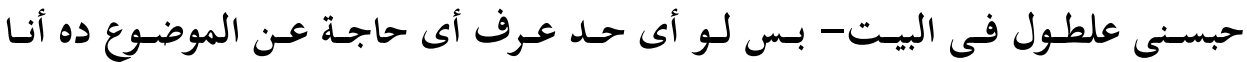
هموتك". وتقول أخري: ":" جوز أمى كان بيكدب كتير ويفترى عليه وكانت ماما بتصدقه

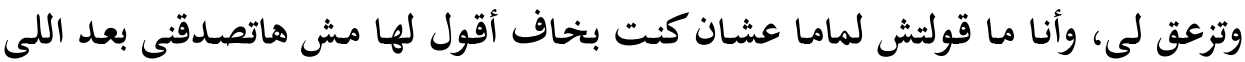

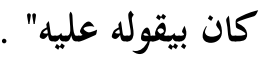

وحينما تحاول الضحية إتخاذ موقف إيجابى ، لا تجد من يساندها من الأهل ، عندها تحاول التصرف من تلقاء نفسها ،فقد تلجأ الضحية للهروب من المنزل ومواجهة مصير

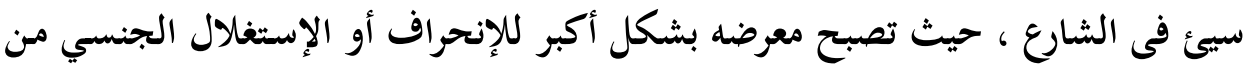

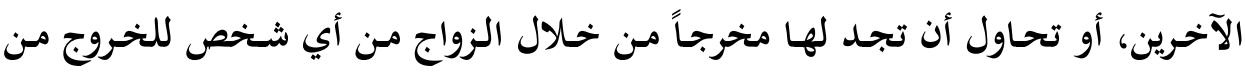
الأسرة وانقاذ نفسها من العنف الجنسي الموجه لها داخل الأسرة ، حيث حاولت إحدي الضحايا التى كان الأب يقوم بالتحرش بها الزواج من شـص تقدم لها، ووافقت عليه بالرغم من عدم حبها له، من أجل الهروب من الأب حيث تقول الضحية" عشان أترحم من أبويا بس بالحلال" ولكن الأب أصر على فسخ الخطبة حتى تظل إبنته معه ، أو قد لد تلجأ الضحية الى الطلاق من زوجها لعدم قدرته على وقف العنف الجنسي الممارس معها من قبل أبيه وهو ما فعلته إحدى الحالات.

وحينما تقرر الضحية إجتيـاز حـاجز الخوف من الأهـل، وتقوم بتبلغيهم مـا يحـدث

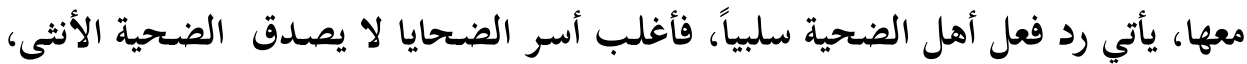

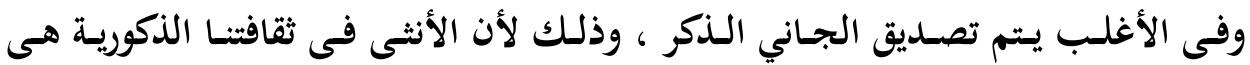

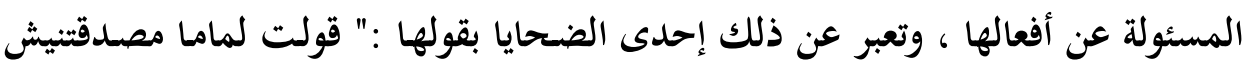

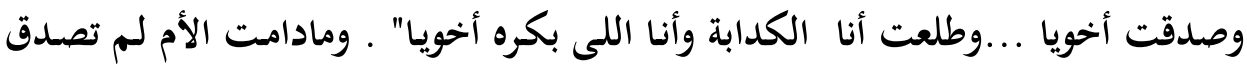
إبنتها، فالإبنـة توقعـت أن لا يصـدقها الأب أيضـا، فلم تحـاول أن تفتح الموضسوع معـه، ولكـن اختـارت أن تهرب مـن المنزل للأبـد ، وتعبر عـن ذلك بقولها: " ماحسدش كـان بيصدق أن ده بيحصل وطالما ماما ماصدقتش يبقى بابا مش حيصدق فهربت من البيت". 
وتقول أخري: " أخويا أعترف قدامهم وقالهم أنا مش عارف أنا عملت كده ليه؟ وقلت

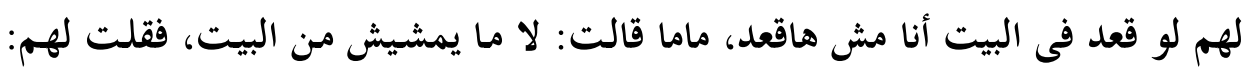

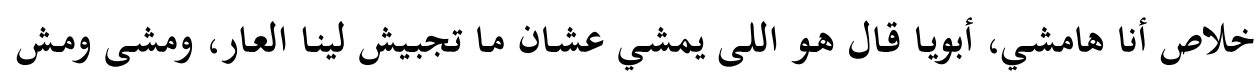

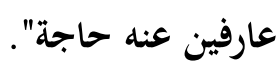

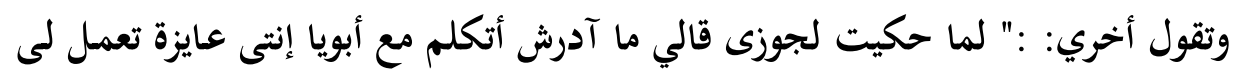

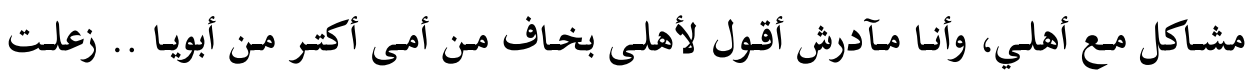

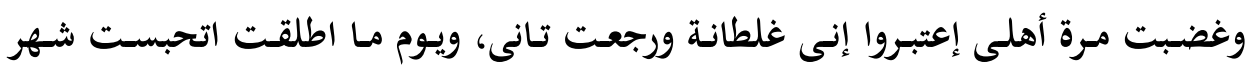

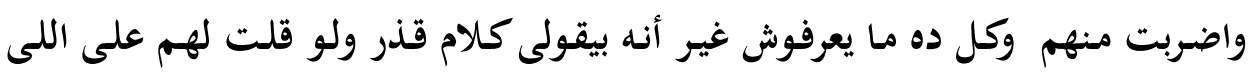

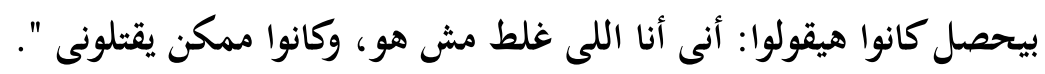

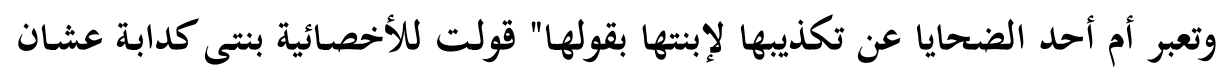

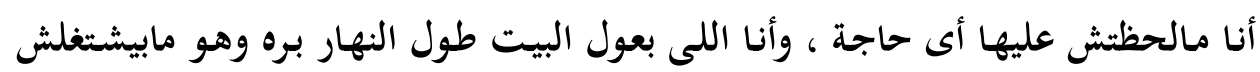

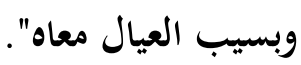

وفى بعض الأحيان لا يكتفي الأهل بعدم تصديق الفتاة، ولكن يمكن أيضاً عقابها

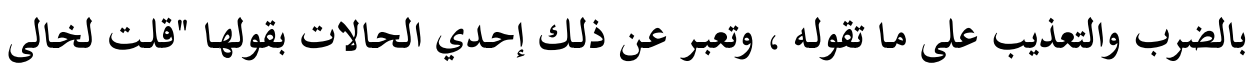

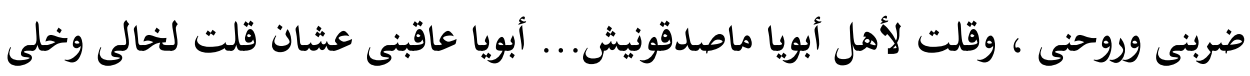

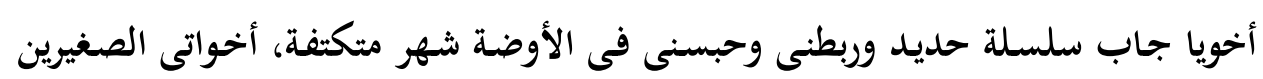

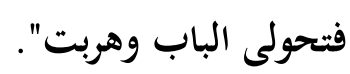

وعندما تحاول بعض الأسر اتخاذ الإجراءات القانونية ضد الجاني قد تقف أمامهم

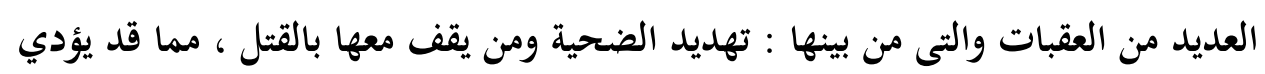

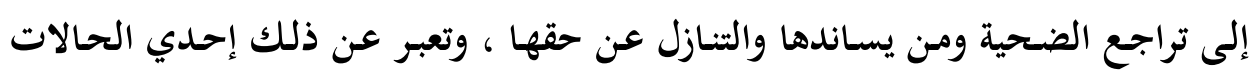

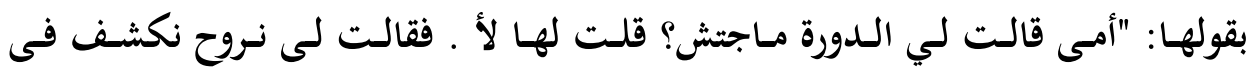

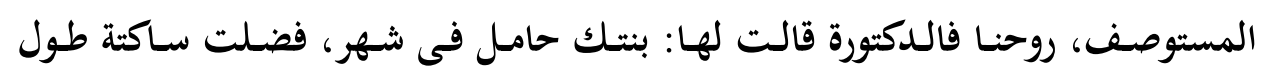

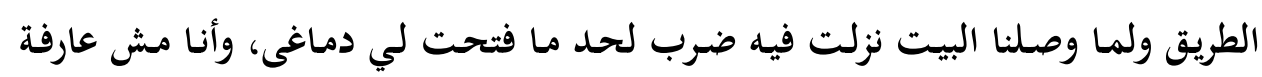


أقولها أيه، وأبويا كان فى الشغل وخحايفة تقوله، وبعتـت لخالى، ولمـا كلمنى قولت له

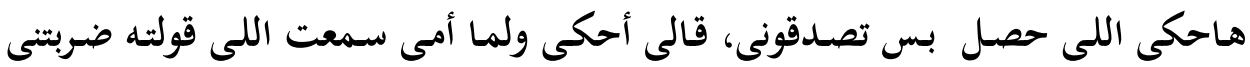

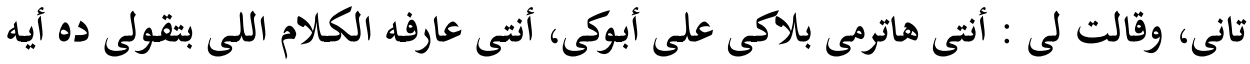

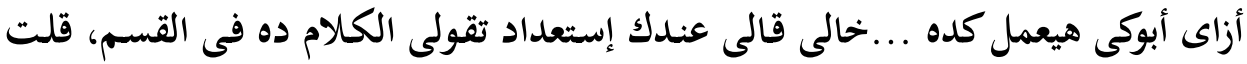
له: آه ، فروحت عملت محضر، فجم خـدوه ، قعـد يومين فى القسم ، فجـم عمـامي زعقوا لأمى وضربوها ومسكونى بهدلونى ، وقالوا لها تاخدى بنتك وتروحى تتنزلى عن تهن المحضر يأما هنموتك أنتى وأمك، واتنزلت وطلع". هـ الأسباب والدوافع الكامنة وراء ممارسة العنف الجنسي ضد ضلى المحارم:

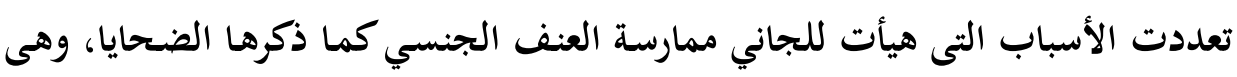
كالتالى بالترتيب: - تعاطى المخدرات( خمسة حالات): أن تعاطى المخدرات يعد أحد لهديات

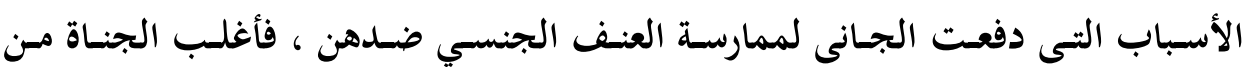
متعاطى المخدرات والمسكرات. - استغلال الرجال لقوتهم الجسدية وسلطتهم الذكورية على محارمهم لاستغلالهم جنسياً

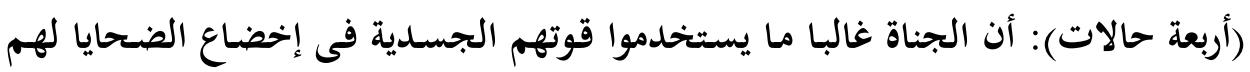

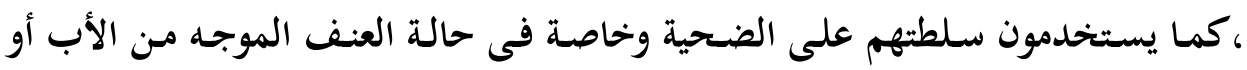
الأخ وذلك لأنهم هم الذين يتولون أو المسئولون عن تربيتهم وحمايتهم. حيث ذئه ذكرت

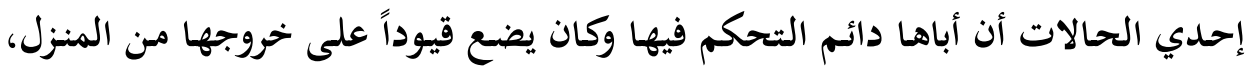

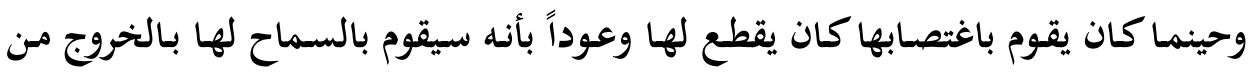

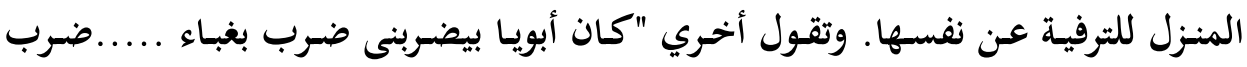
بالشومة تخن كده وطول كده أنا جسمي معلم". -تحمل الأم مسئولية الإنفاق على الأسرة فى ظل تعطل الزوج، واضطرارها الى العمل لساعات طويلة خارج المنزل(حالثان): حيث أشار الضحايا الى أن أغلب مهن أمهاتهم تتركز فى الأعمال الخدمية: كتنظيف المنازل، والتى تجعل المرأة تعود الى منزلها مرهقة 
ومتعبة وغير قادرة على تلبية متطلبات زوجها الجنسية والتى يسعي لإشباعها من خحلال ما هو متاح أمامه وهم محارمه، ويساعد على ذلك ضعف المنظومة الدينية والأخلاقية لهؤلاء الأفراد.

- التفكك الأسري( حالتان) :أشار الضحايا الى أن العيش وسط أب وأم منفصلان وأبناء

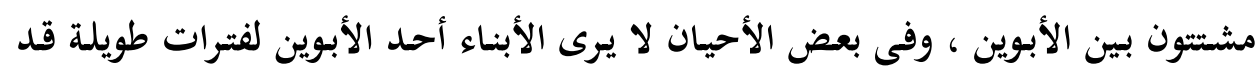

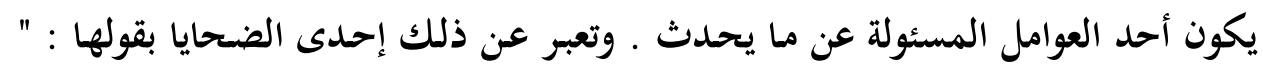
ماما رضيت بأننا نروح عند أبويا عشان مايقولش إنها مكرهـ العيال فيه. هو ما شفنيش

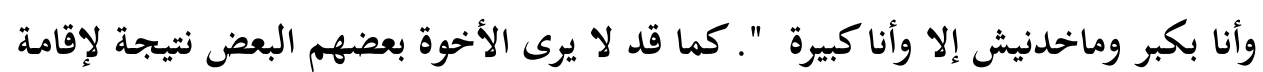

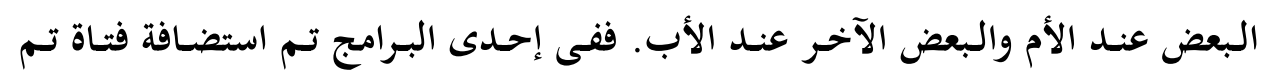

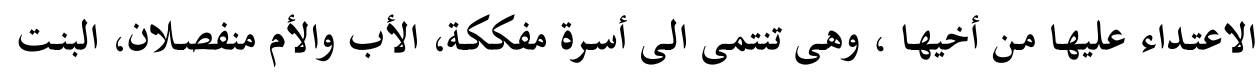

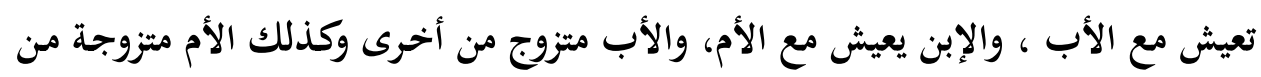

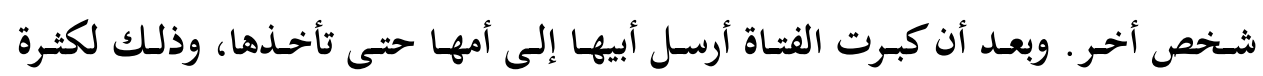

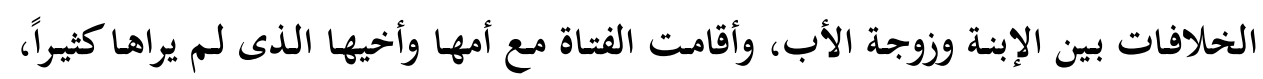

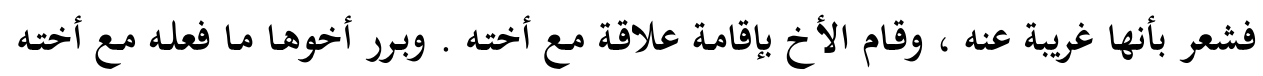

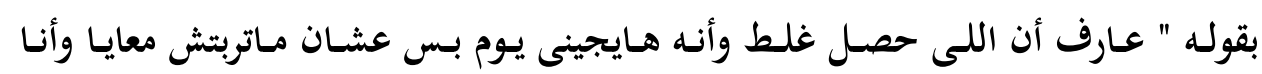

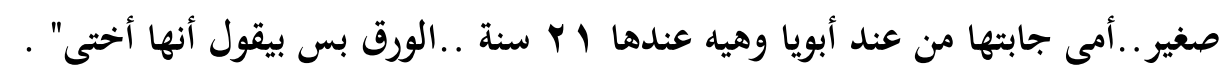
- غياب المرأة فى حياة الجاني (حالة واحدة) : فعدم قدرة الجانى على الزواج لإشباع إنى

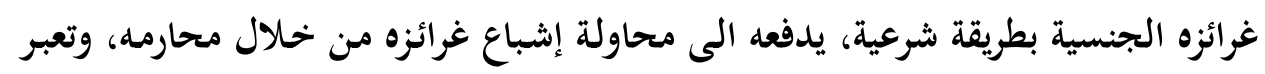

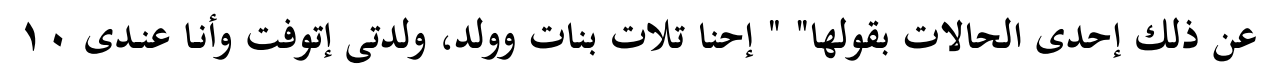
سـنين .... طلعنى من المدرسـة عشـان أشـتغل، إثـتغلت فى مصـنع ملابس عمل معايـا حاجات أنا ما استهلش منه كدة ". -غياب دور الأسرة التوجيهى للأبناء (حالة واحدة) : أن ضعف الحوار بين الآباء وأبنائهم من خلال توضيح ما هو صحيح وما هو خاطئ ما ينبغى أن يفعله الأبناء من سلوكيات 


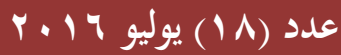

إيجابية وما ينبغى أن يتركوه؟ لأنه لا يتماشي مع الأخلاقيات والعادات والتقاليد قد يعد

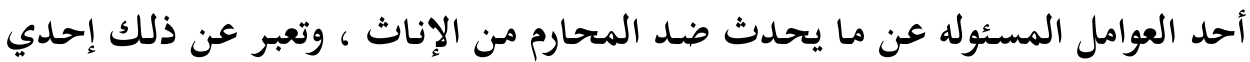
الضحايا بقولها " ماما وبابا عايشين مع بعض بس بابا بيرجع تعبان من الشغل وماكنش

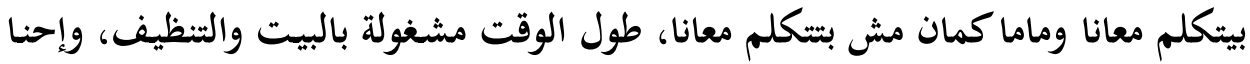
تلات بنات وولد وعلاقتنا ببعض إننا أخوات مانعرفش حاجة عن بعض " ولغياب دور الأم والأب مع الأبناء يفتقد الأبناء لمشاعر الحنان والعطف، كما غاب عنهم أدوارهم تجاه بعضهـم البعض : دور الأب تجـاه ابنتهـ ، دور الأخ تجـاه أختـه.. فأصسبح أفراد الأسـرة أغراب عن بعضهم البعض وتعبر عن ذلك إحدي الضحايا بقولها: " أخويا أكبر منى بسنة

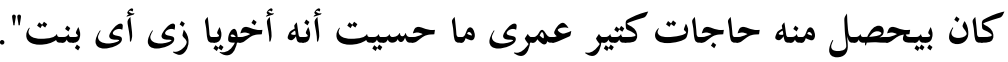

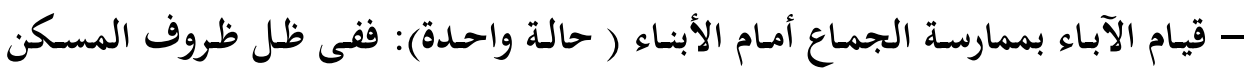
الضيق والمزدحم وعدم وجود غرفة مخصصة للزوج والزوجة، وإقامـة جميع أفراد الأسرة فى غرفـة واحـدة، حيـث ينـام الآبـاء مـع الأبنـاء ، يضطر الأبـوين لممارسـة الجمـاع أمـام

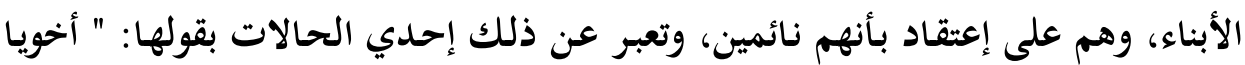
جة قالى سمعتى أمك وأبوكى وهما نايمين مع بعض؟ قلت لة لأ ما سمعتش. على إلى الرغم من إنى سمعت وقولت لماما بلاش تنامى مع بابا تانى باليل عشان لمشى إحنا بنكون سامعين،

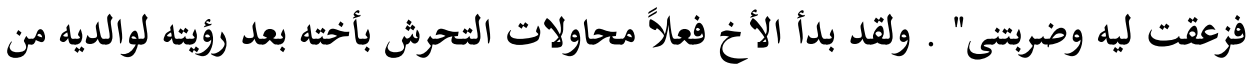

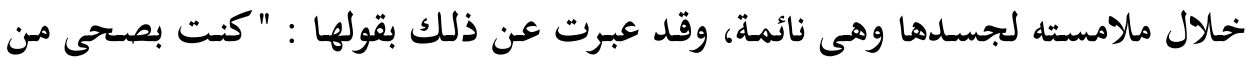
النوم آلاقى نفسي متعرية، أو بيحسس عليا، أو بدخل الحمام بلاقيه بيبص عليا، وقلت له هقول لبابا وماما، لكن هو كان عارف إني مش هآدر أقول عشان ضربتنى قبل كده".

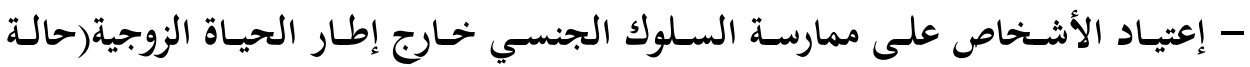
واحدة): حيث نجد أن بعض الجناة لهم تاريخ عائلي فى الإعتداء الجنسي. وتعبر عن ذلك إحدى الحالات بقولها:" قعدت مع حماتى وحماي فى شقة واحدة كنت بخدم خمسة وحماي السادس". ووالد الزوج سمعته وسيرته سيئة بين الجيران والأقارب، وذلك 
لأنه معتاد على القيام بالاعتداء الجنسي على النساء سواء كانوا من أقاربه أو جيرانه، ولم

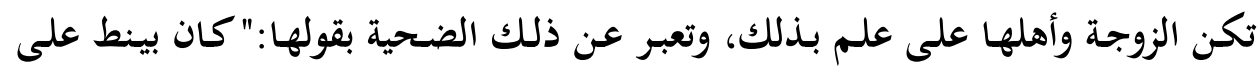

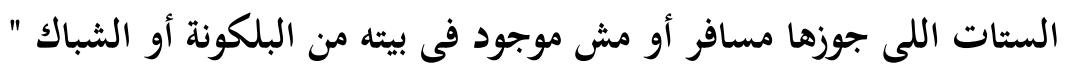

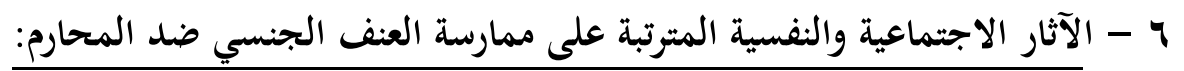

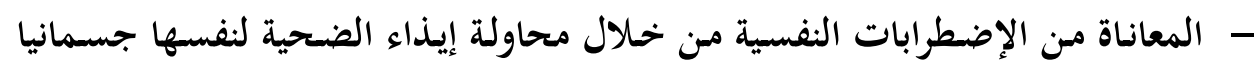

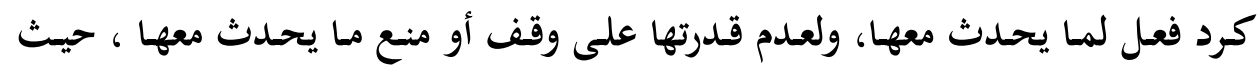

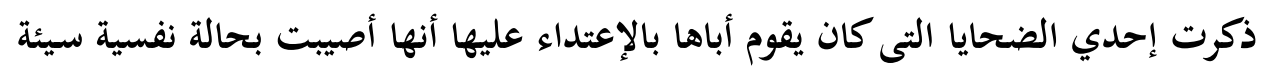

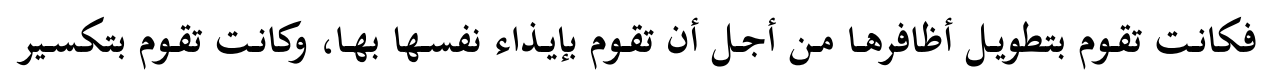

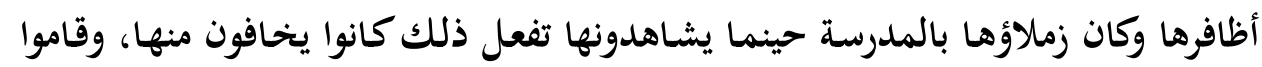

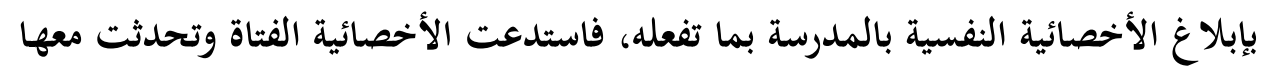

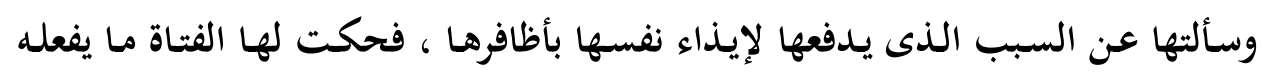
أبوها معها.

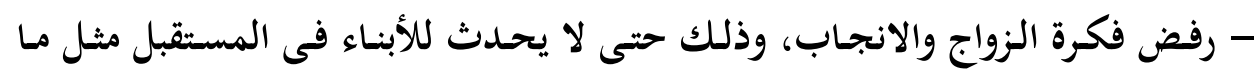

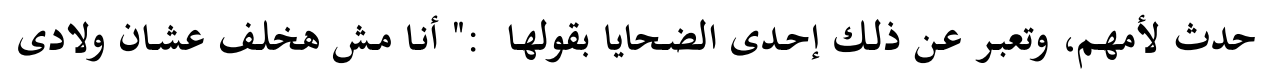

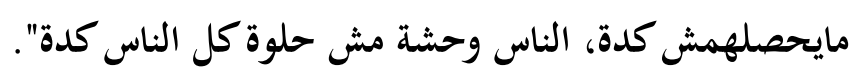
- الشعور بالخوف وعدم الإحساس بالإمان وخاصة إذا كان الجاني حراً طليقاً ، كذلك كلك الكئل

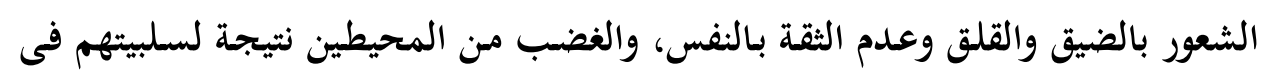

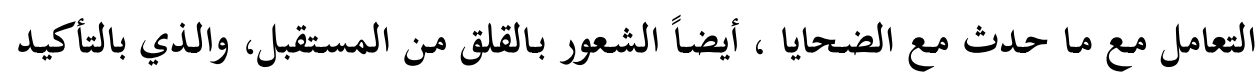

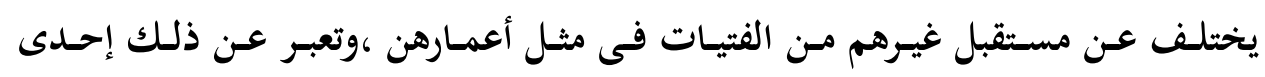

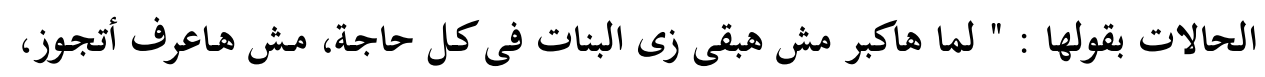

$$
\text { مش هيبقى ليه بيت ". }
$$

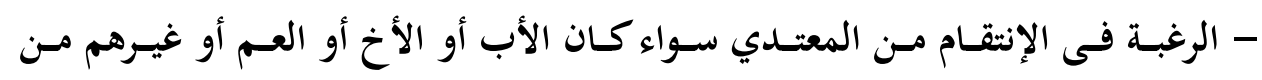

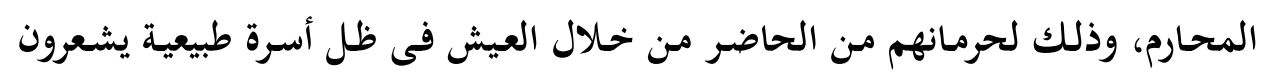


بالأمان فيها ، والهروب إلى الشارع ظناً منهم بأنه أرحم لهم من إسرهم، بالإضافة إلى

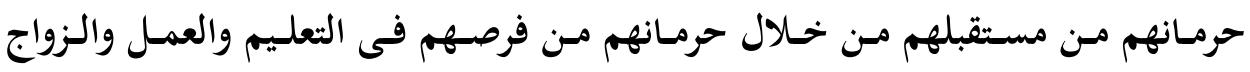
والإنجاب.وتعبر عن ذلك إحدي الضحايا بقولها: " الشـارع وحش أنـا بقى لى خمس تصس شهور فى الشارع كل يوم أبويا بيخرج ويجي ويروح ينام فى البيت، وأنا خمس شهور مش بـ

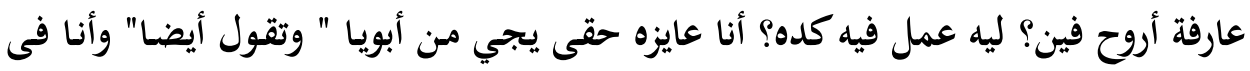

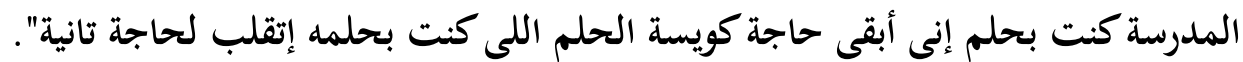

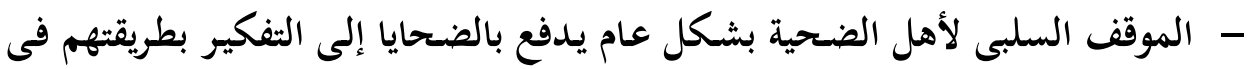

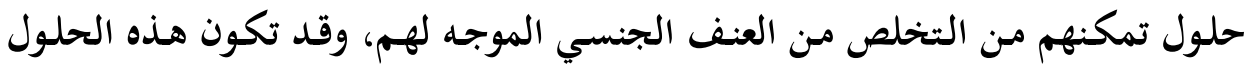
خاطئة تترتب عليها آثاراً سلبية أخرى على الضحية وخاصة أن أغلب الضحايا أعمارهم

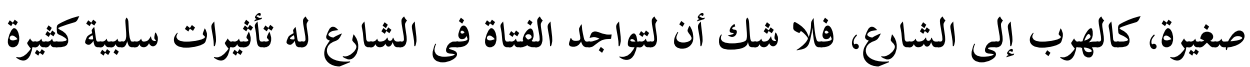

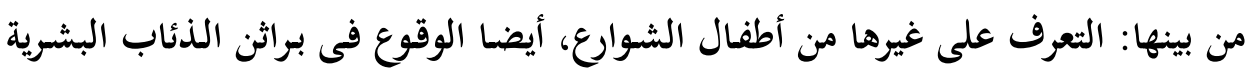

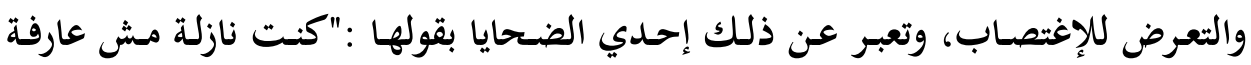

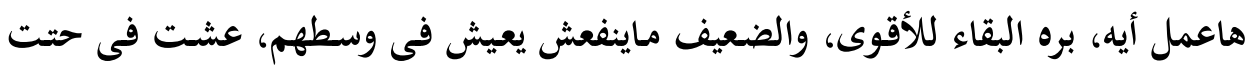

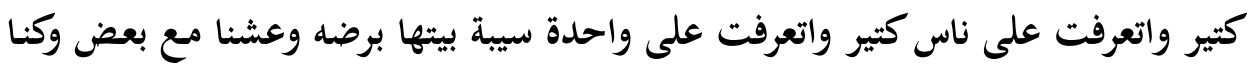

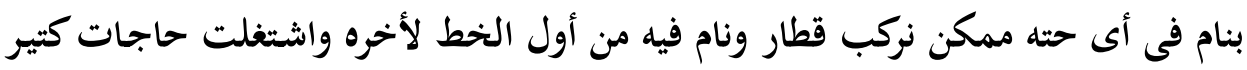

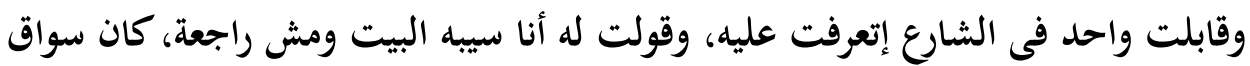
تاكسي عنده • ب سنة وأنا V V سنة، ضحك عليا، وقالى هتجوزك قعدت عنده وفقدت

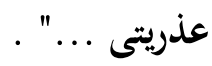
- اختلاط الأنساب بسبب ما ينتج من هذه العلاقة المحرمة من أطفال ، ولكن فى أغلب الحالات

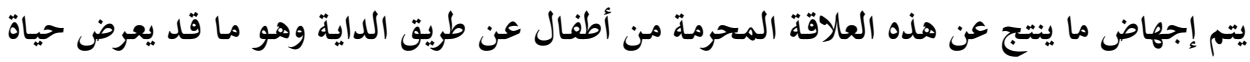

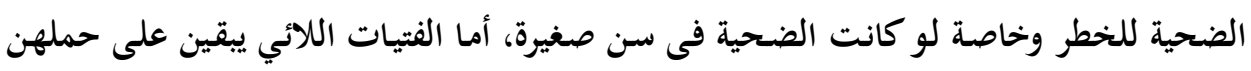
فأنهن يتخلصن منه بوضعه أمام المساجد أو دور الإيواء.

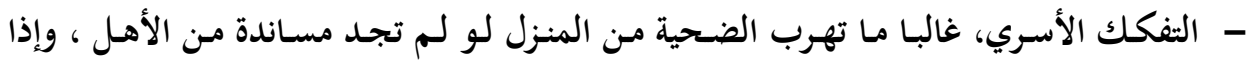

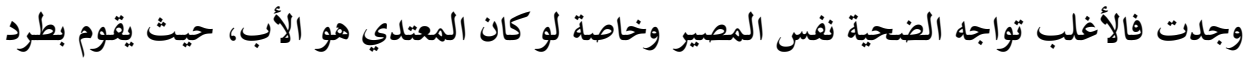


الضحية وأمها مـن المنزل، وبالتـالى لا يجـدون مـأوى لهم فـى ظل سوء أحسوالهم الاقتصـادية ،

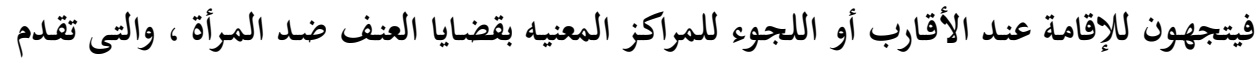

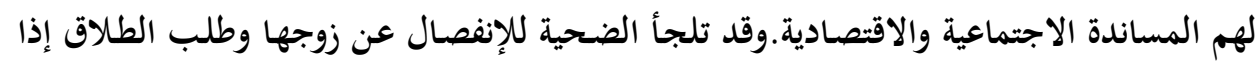

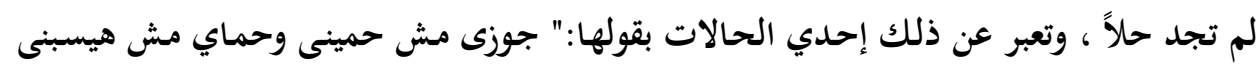

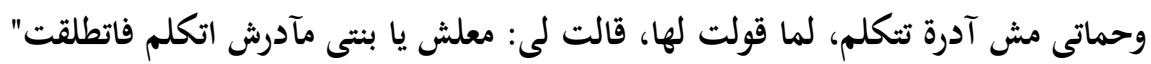

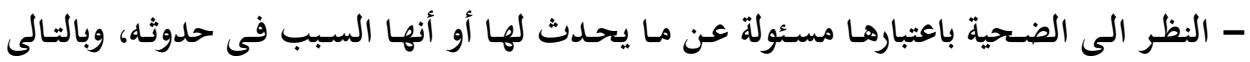
التعامل معها بطريقة سيئة، وتعبر عن ذلك إحدي الحالات التى إعتدي عليها أخيها بقولها: " مامـا

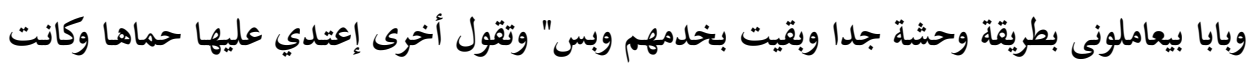

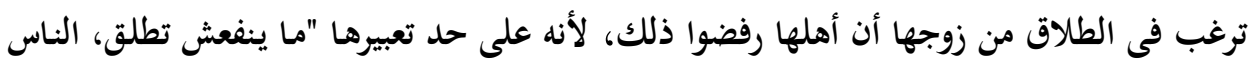

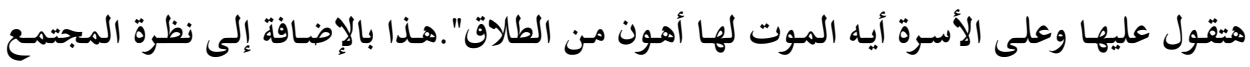

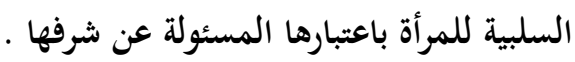

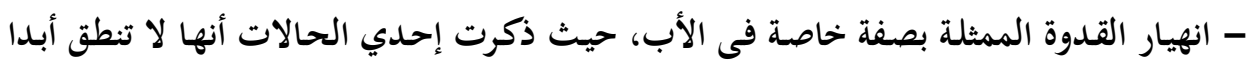

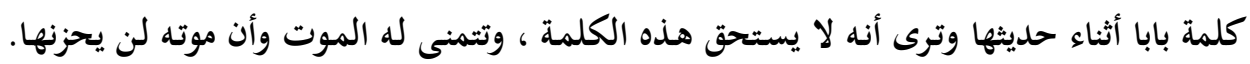

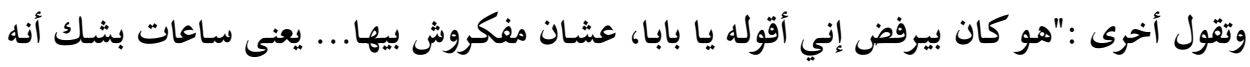
أبويا" .

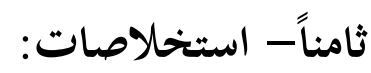
- معظم الضحايا يقيمون بشكل دائم مع الجناة سواء كانوا أخوة أو أباء أو أعماماً أو

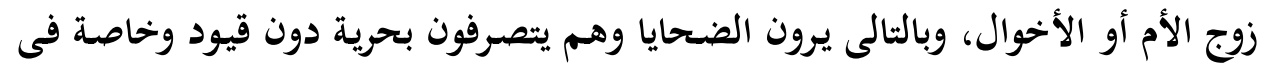

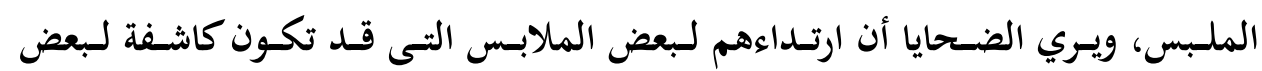

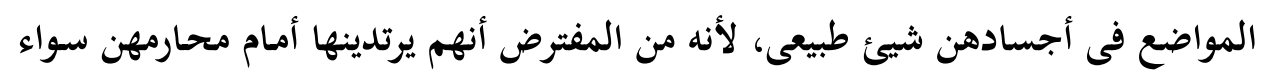
كان: الأب أو الأخ أو العم وغيرهم، والذين يفترض فيهم أنهم مسئولون عن" شرف الهي أهل

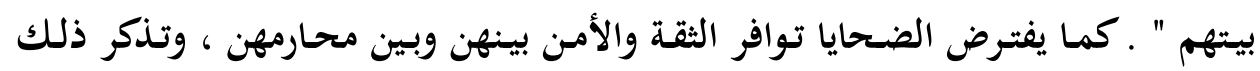

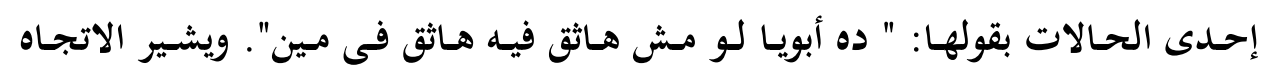

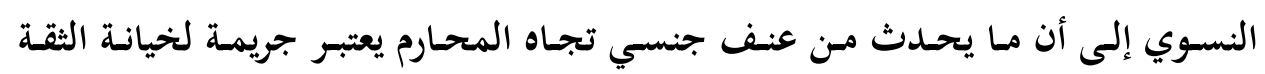




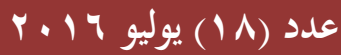

والأمانة، وهى الصفات التى من المفترض أن تكون ملازمة للشخص الذى يتولى تربية أو مسئولية أو ملاحظة أشخاص آخرين. - أغلب الضحايا الذين واجهوا العنف الجنسي أعمارهم صغيرة وهو ما أكدته أحدى أحى الدراسات التى أجريت على سبعة بلدان وهى : كمبوديا وجمهوريـة الدومينكان ومصر

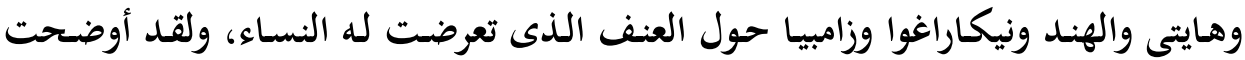

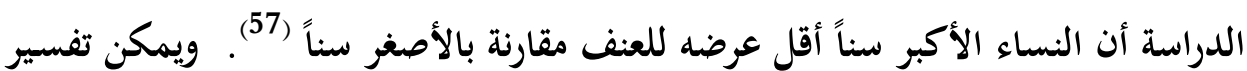
ذلك فى ضـوء مـا يؤكد عليه الاتجـاه النسـوي مـن أن العنف المستخدم نوعى ومـتبط

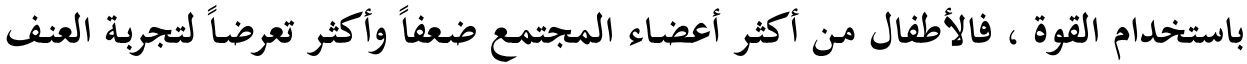

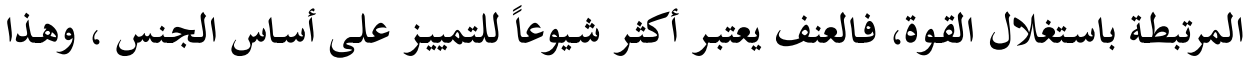
يعنى أن النسـاء والفتيـات كـل يـوم يتعرضـن لتجربـة العنف على أيسلى الرجـال والأولاد الذكور (58)

- أغلب الضحايا مـ الأميين أو الذين يقرأون ويكتبون أو المتسربين من التعليم ، وهو مـا

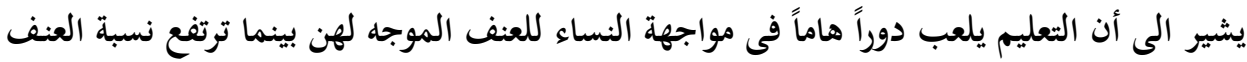
الموجه للنساء غير المتعلمات أو الأقل فى المستوى التعليمى، وهو ما أكدته إحدى الدراسات

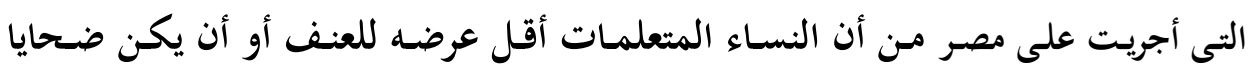
للعنف وذلك مقارنة بالنساء الأقل تعليما (59) - تعرضت أغلبية الضحايا لأشكال متعددة من العنف فإلى جانب تعرضهن للعنف الجنسي تعرضن أيضا للعنف الجسدى من خلال الركل والصفع والضرب ـ أيضا تعرضن للعنف النفسي والعقلي أو لئل العاطفى والذى يشتمل على الإستخفاف المستمر بالضحية وإذلالها، والتهديد ضد الأشياء العزيزة والإجبار على ممارسة الجنس من خلال إستخدام القوة البدنية أو الثهديد أو التخويف (60) ، حيث تعرضـت الحالات للإجبار على ممارسة الجنس من خـلال استخدام القوة البدنية ، كما

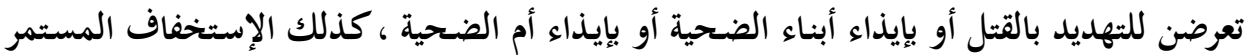

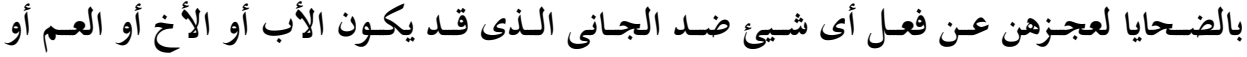


- معظم الجناة من متعاطى المخدرات والمنشطات ، ولقد أوضحت إحدى الدراسات أن مفهوم

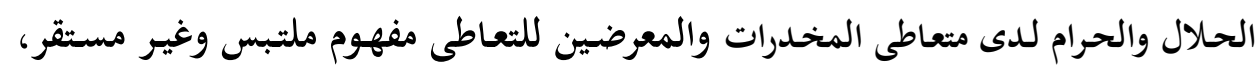
بحيث يتم تطويعه فى بعض الأحيان وفقاً للموقف، ويأخذ فى بعض الأحيان صيفاً تبريرية

- معظم الجناة من العاطلين أو من هم دون سن العمل أو على المعاش أو من العاملين فى مهن حرفية. - أغلب الجناة من المتزوجين بواقع ( ثمانى) حالات يليها غير المتزوجين بواقع ( سبع) حالات، والأرامل بواقع ( حالة واحدة). - العنف الجنسي الموجه للمحارم تمثل فى الإغتصـاب (تسع) حسالات، هتلك العرض ( أربع)

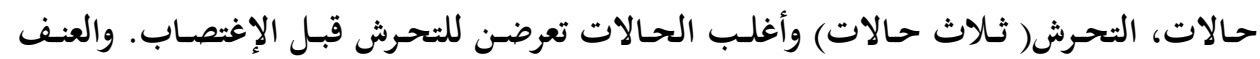

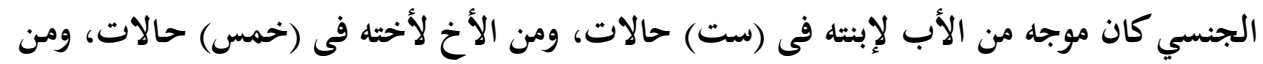

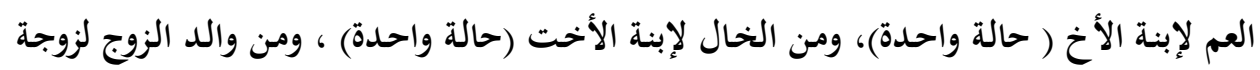

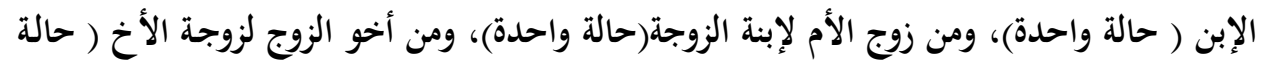
واحدة).

- يتزايد العنف الجنسي الموجه للمحارم فى المناطق الحضرية العشوائية أو الشعبية الفقيرة مقارنة

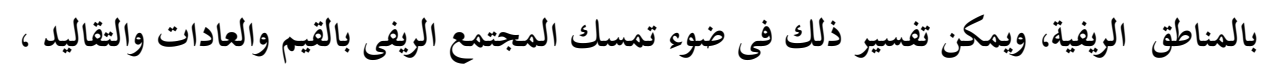

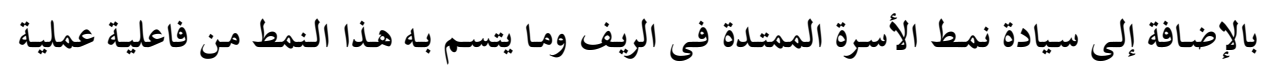

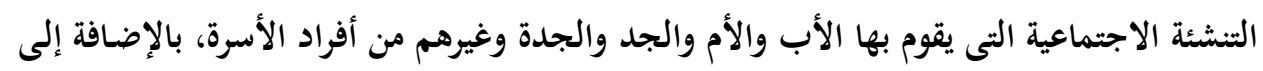

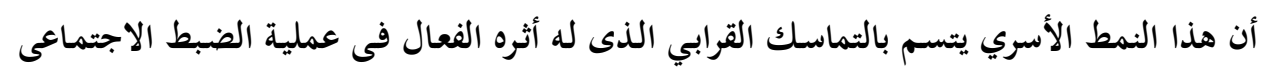
وفى العلاقات الاجتماعية التى تربط أفراده (62)

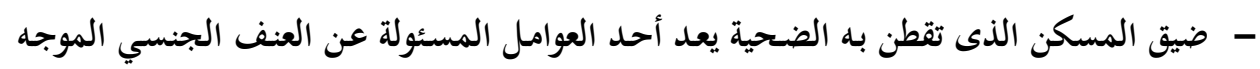

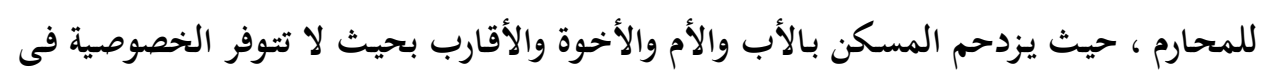
أماكن النوم والاستحمام.

- أن التدين أصبح تدين شكلى أو مظهرى ـ فالجوانب الروحية التى كانت تشكل غذاءً معنوياً

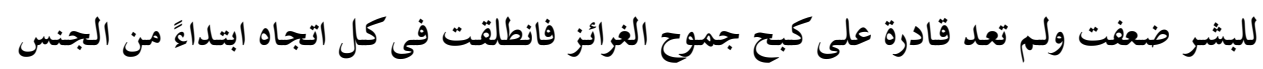




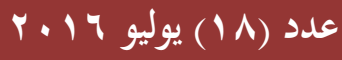

والإغتصاب ومروراً بالمعاشرة الجنسية للصغار، وانتهاءً بغشيان المحارم. ولقد كان من الطبيعى أن الن النها ينعكس ذلك على القيم المنظمة للحياة الأسرية ، فقد برزت القيم الفردية لتحكم التفاعل الأسري

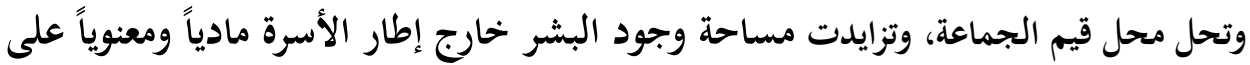
حساب تقلص وجودهم مع بعضهم البعض ، فلقد أصبح أفراد الأسرة يعيشون مع بعضهم

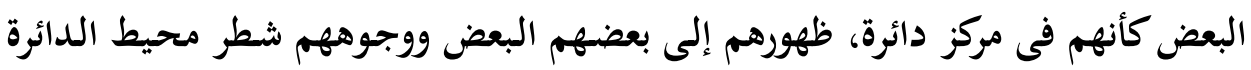

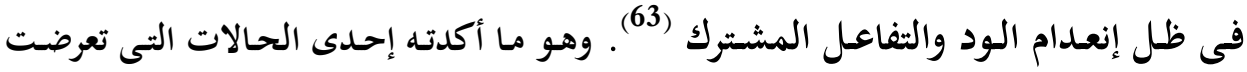

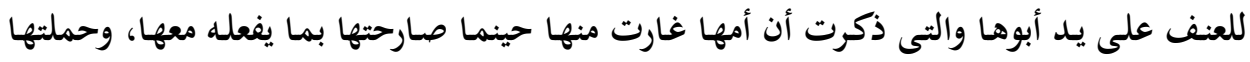
مسئولية مـا حدث معها، وأنها ستكون السبب فى "خراب بيت أمها" . وتعرض الفتاة للتحرش وهتك العرض من أبيها منذ أن كان عمرها سنتين وإستمرار تعرضها للعنف حتى بلغت 17 سنة 17 دون أن تشعر بأن هناك شيئا يحدث معها.

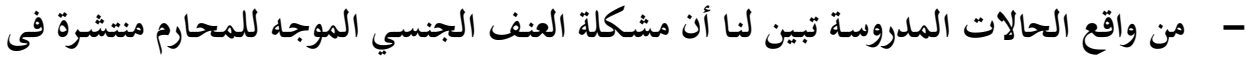

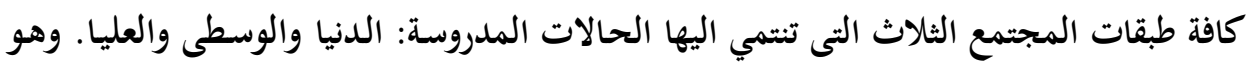
ما أكده أيضاً الخبراء حيث يتردد على المراكز الثلاث نساء من مختلف الطبقات الاجتماعية

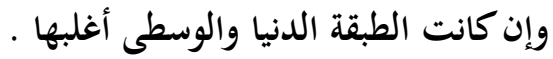

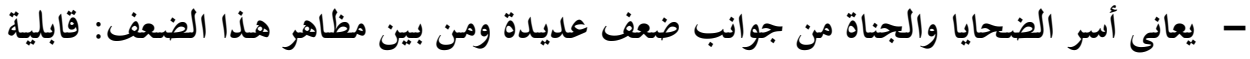

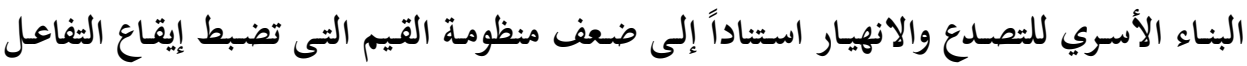

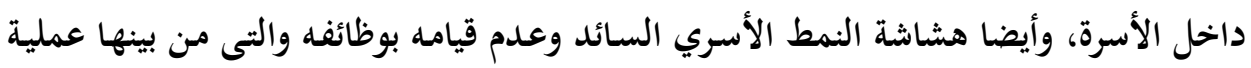
التنشئة الاجتماعية ، بالإضـافة إلى ذلك بروز ثقافة الجنس والغرائز نتيجة لما تعرضسه وسائل

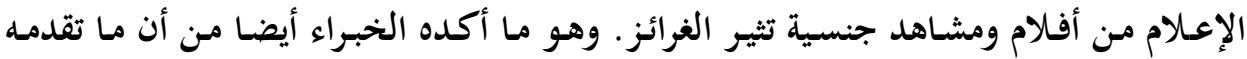

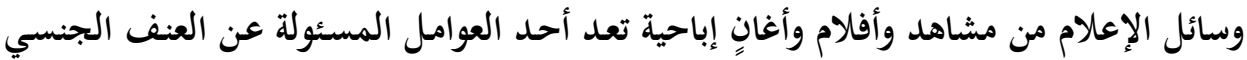

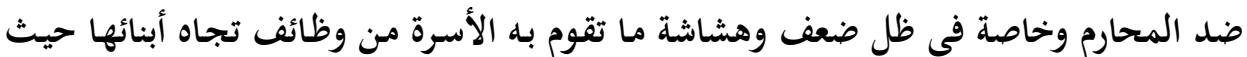
تنامى دور وسائل الإعلام وتكنولوجيا المعلومات التى سعت إلى نشر أفكار وقيم أخلاقية غريبة على المجتمعات التقليديـة، وهي الأفكار التي تميل إلى التحرر ونشـر الإباحيـة في الحيـاة

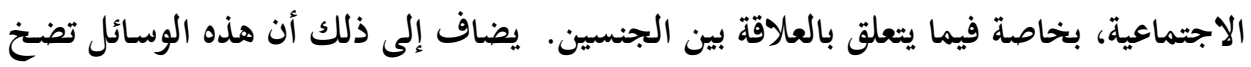


الأفلام الإباحية، التي تتدفق عبرها القيم والعواطف التي توسع مساحة الغريزة في حياتنا، وأصبح

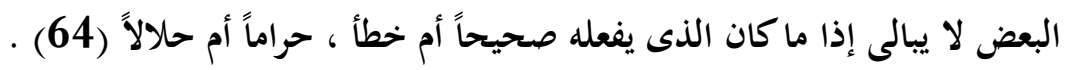

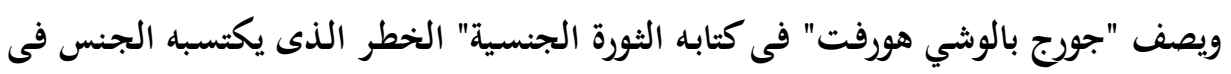

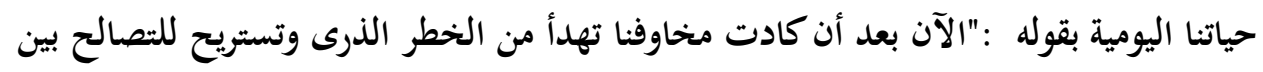

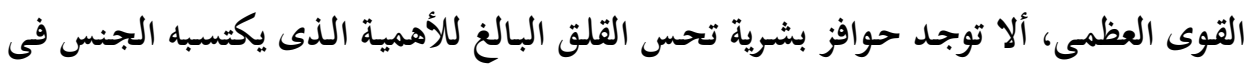

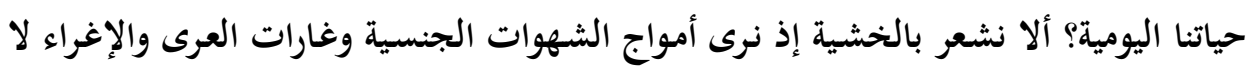

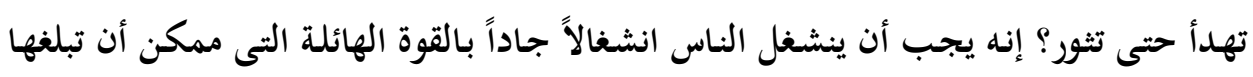

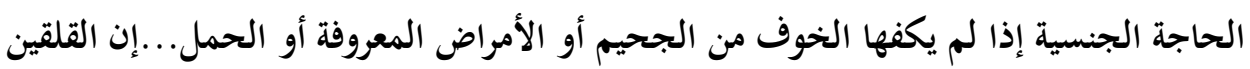

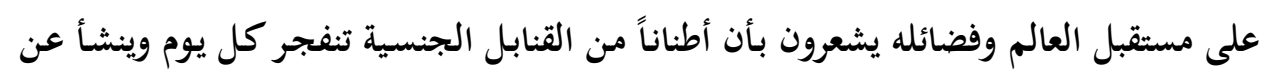

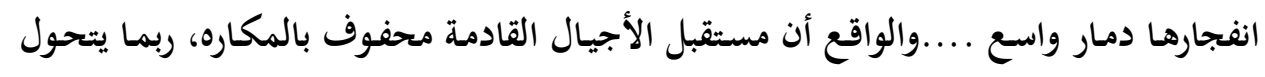

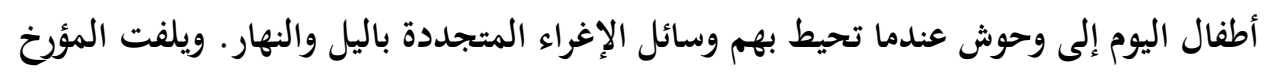

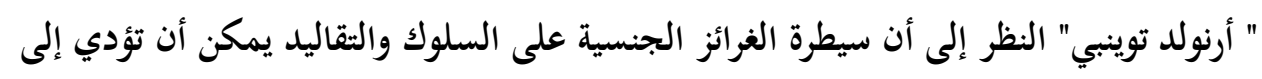

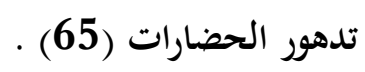

- كثفت الدراسة عن ضعف التفاعل الاجتماعى بين الآباء بصفة عامة والأم بصفة خاصة وبين

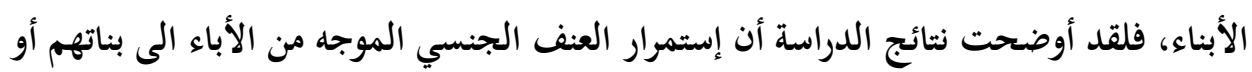

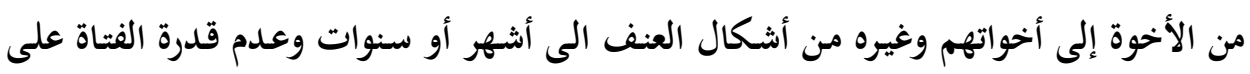

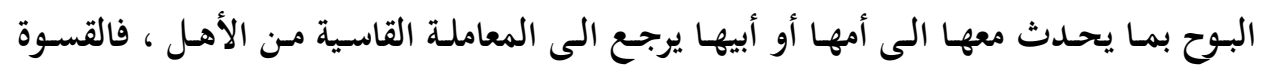

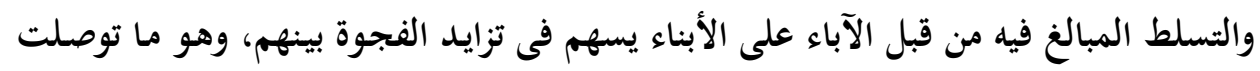

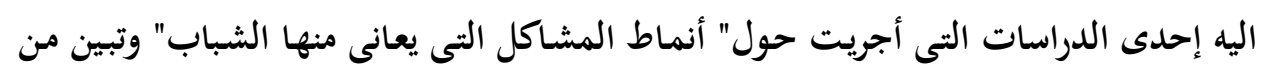

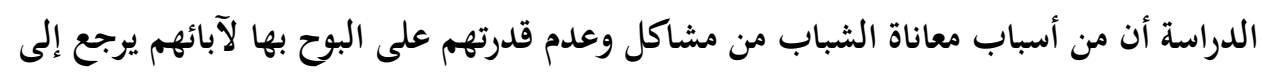

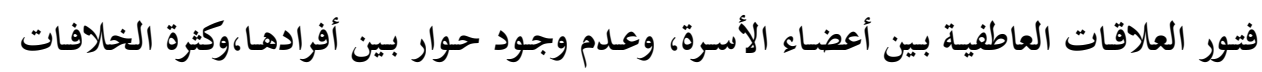

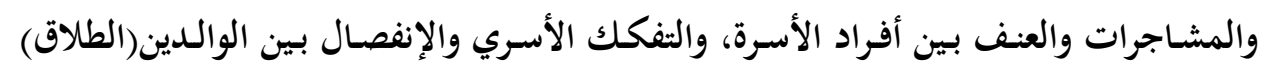

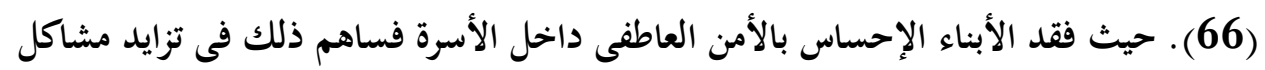

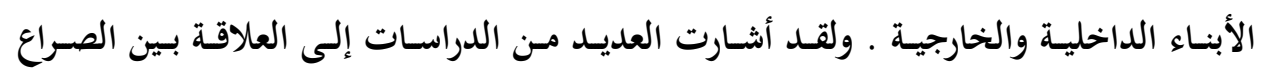

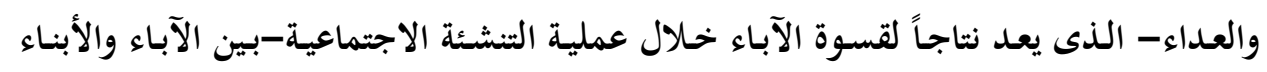




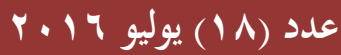

ومشاكل المراهقون السلوكية وتأثير ذلك على تآكسل الثقـة بـالنفس والاكتئـاب والقلق لدى

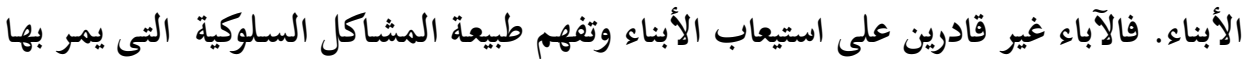

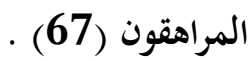
- رؤية الأبناء للأب والأم أثناء قيامهم بالجماع الجنسي يساهم فى نضجهم الجنسي السريع ورغبتهم الشديد فى محاكاة ما يرونه .ويشير إلى ذلك نظرية التعلم الاجتماعى حيث تفترض

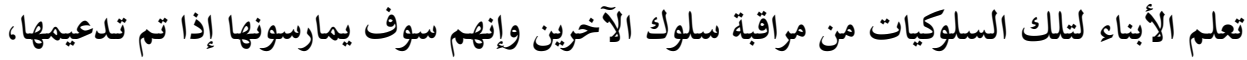
وبالتالي فالسلوكيات العاطفية والجنسية يتم إكتسابها من خلال مراقبتهم للقيم والممارسات الجنسية فى بيئتهم ومن ثم يحاولون محاكاة هذه السلوكيات (68) ـ وتعتبر وسائل الإعلام من فئم

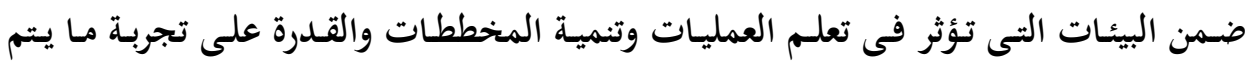

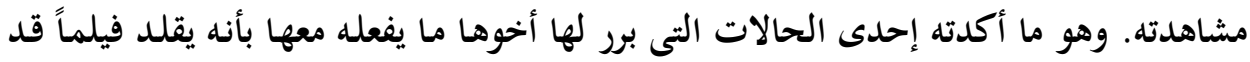

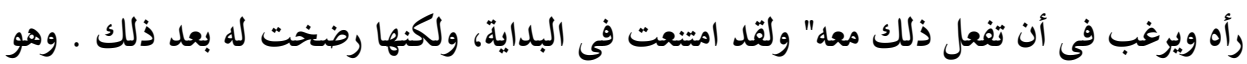
ما يشير إلى حدوث خلل فى عملية التنشئة الاجتماعية وخلل فى تكلى تكوين الضـمير الإنسانى

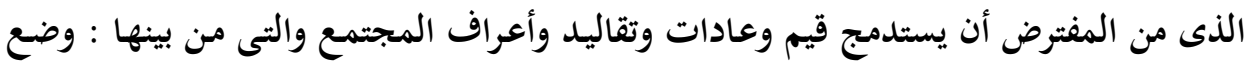

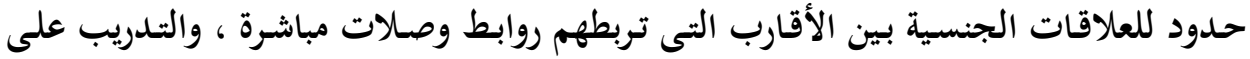

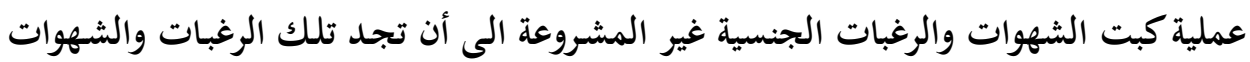

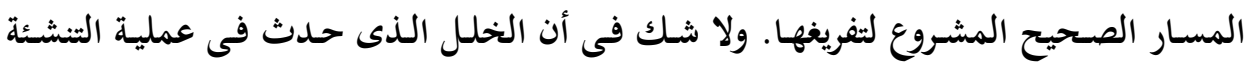

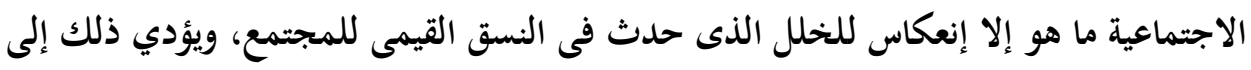

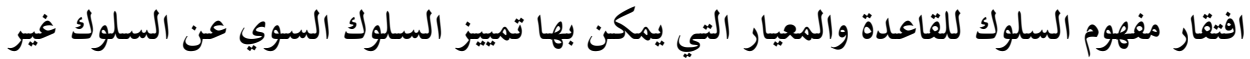

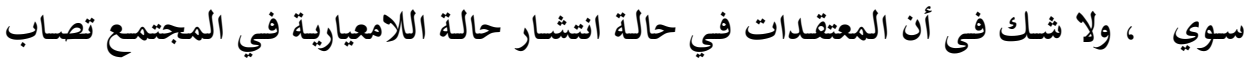
بالضعف والوهن وينعكس ذلك على البناء الأسري.

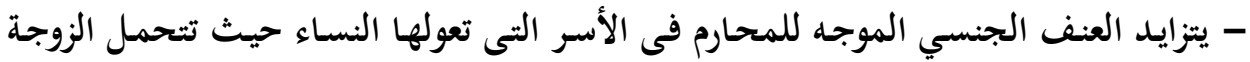

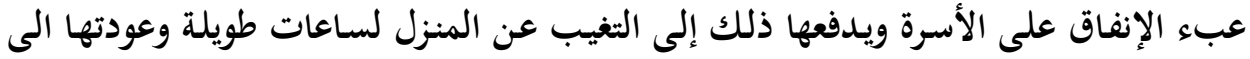

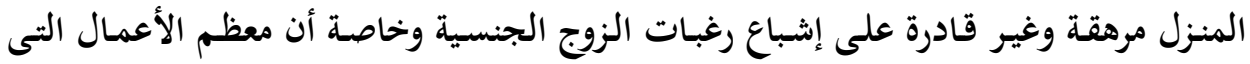
يقمن بها هى الأعمال الخدمية المرهقة. 
- رد فعل النساء والفتيات تجاه ما حدث معهن من عنف جسدي وجنسي ونفسي كان رد فعل

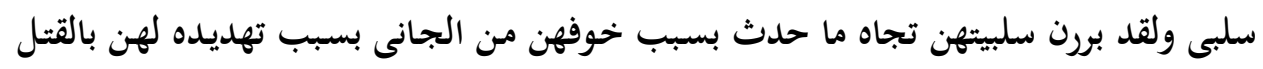

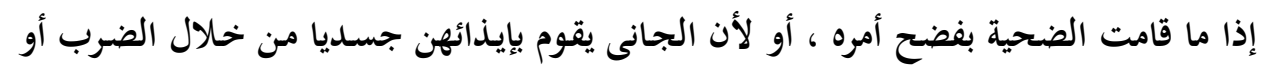

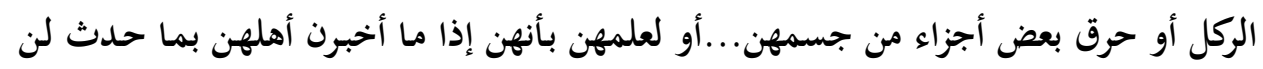

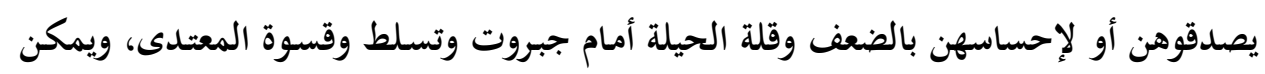

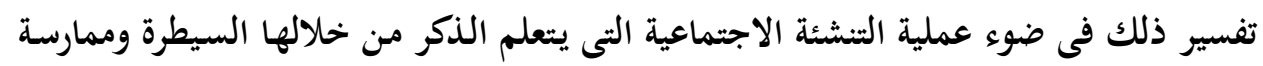

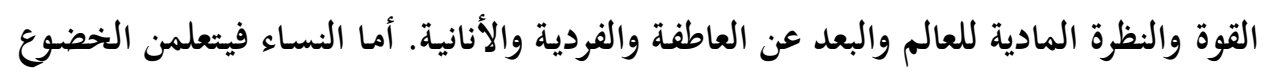

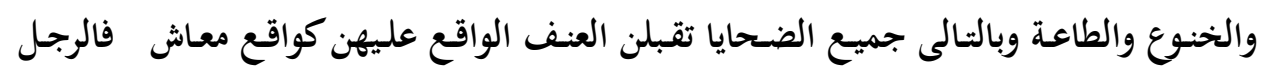

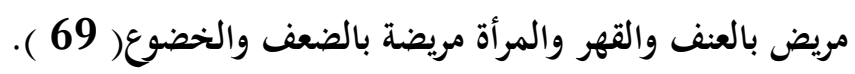

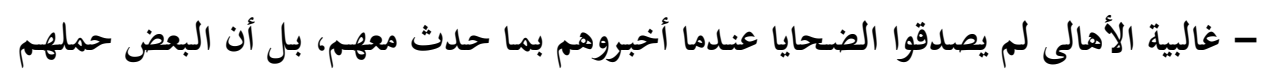

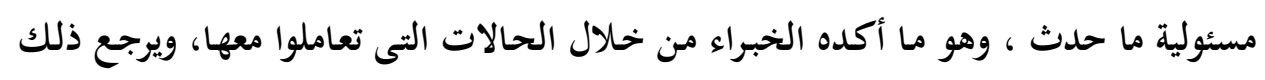

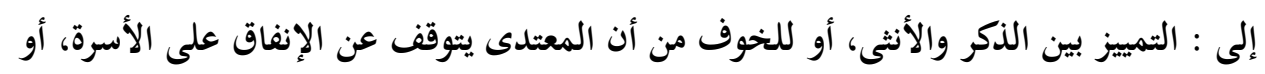

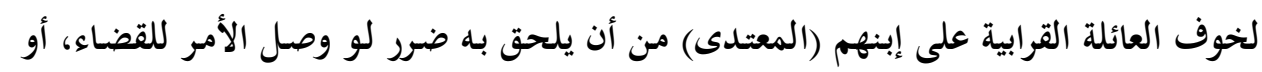

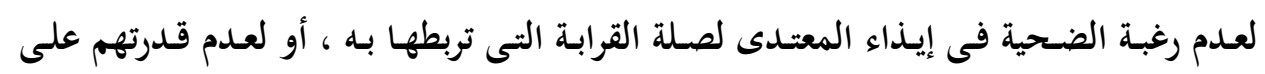

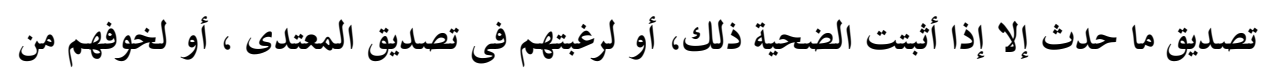

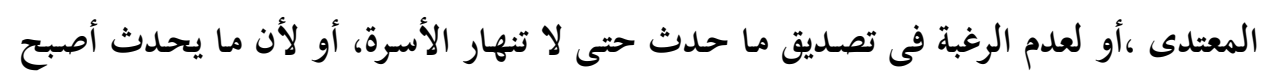

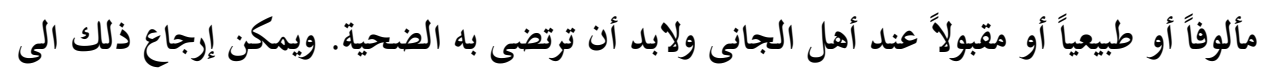

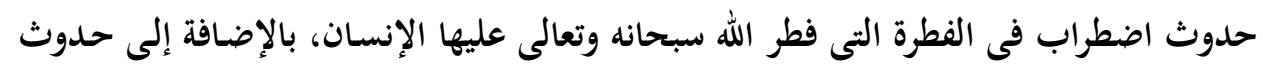
خلل فى الأنا العليا أو المثالية (الضمير) التى تشتمل على القى القيم والمبادئ الأخلاقية السائدة

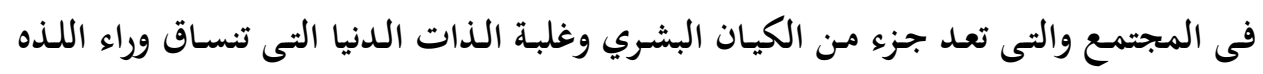

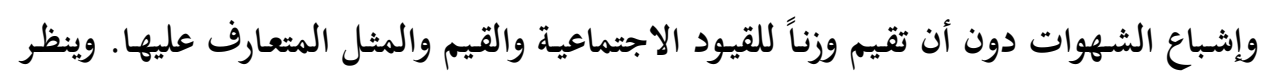

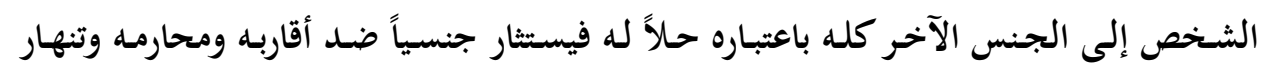

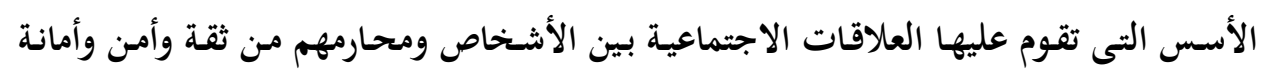

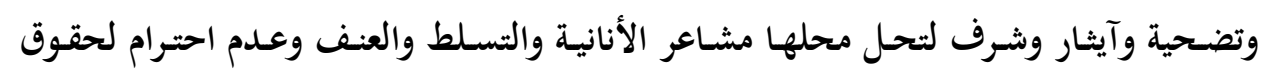

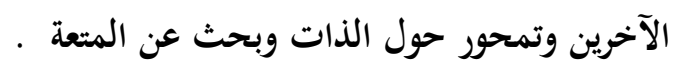


- غالبـاً مـا يتوقـف العنف الجنسي الموجـه للضـحية عنـــ معرفـة الأهـل بـالأمر، وفى معظم

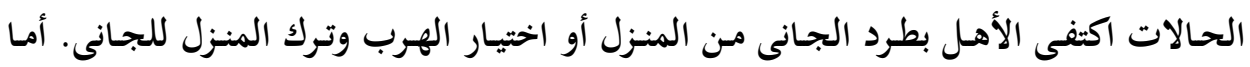

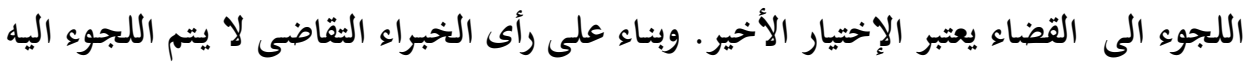

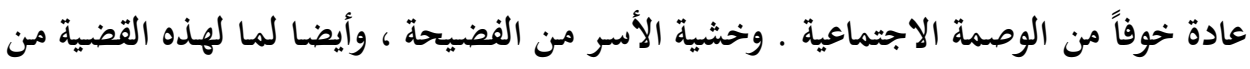

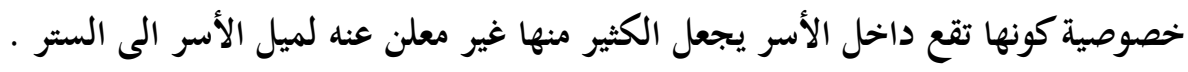

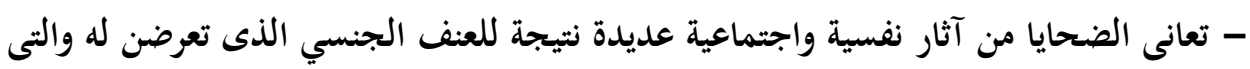

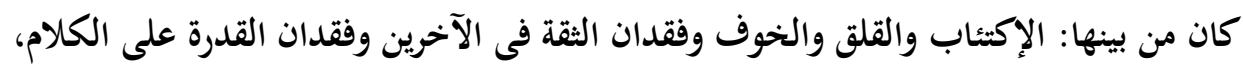

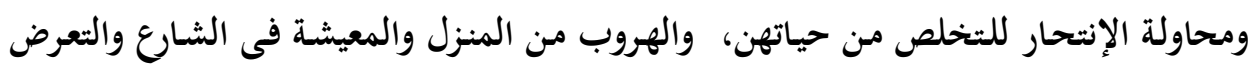

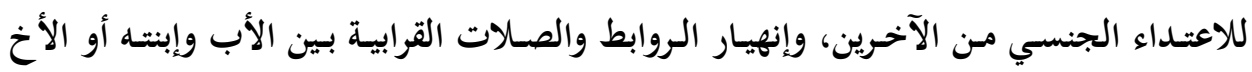

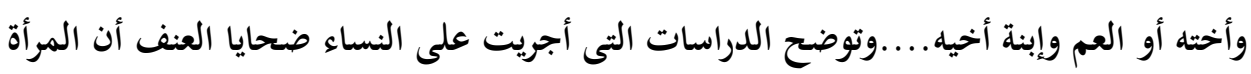

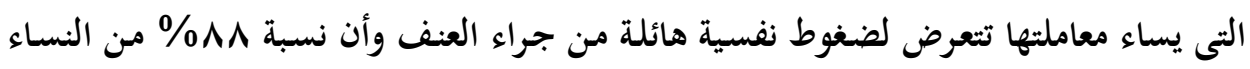

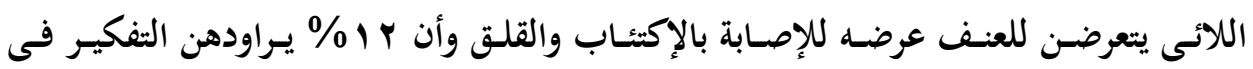

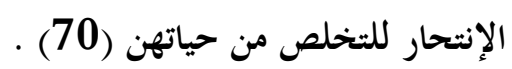

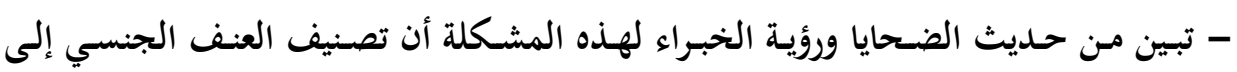

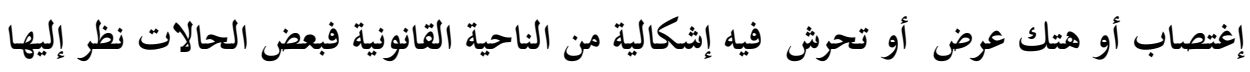

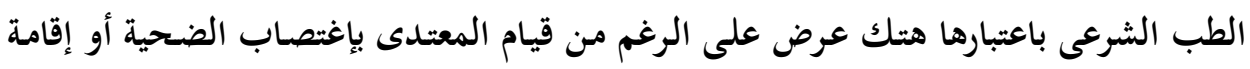

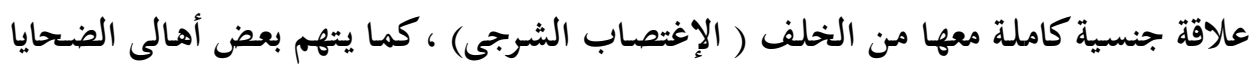

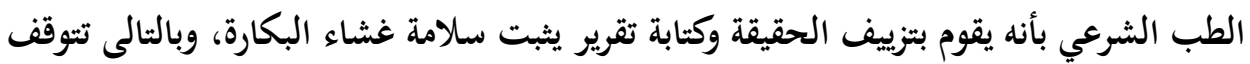

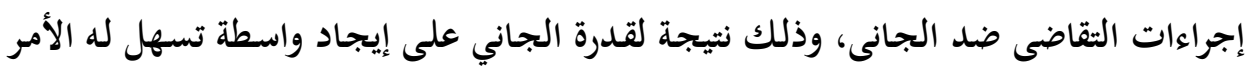

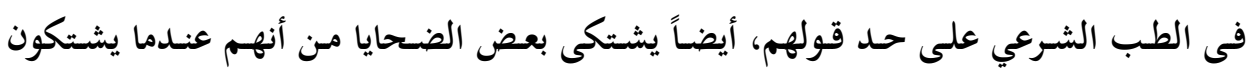

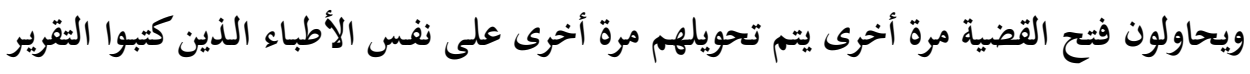

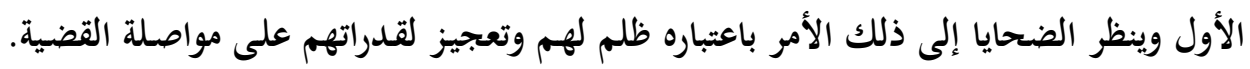

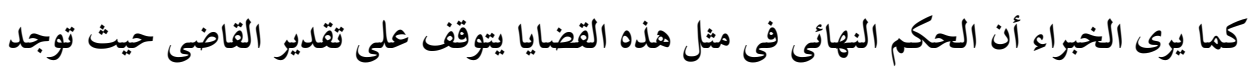

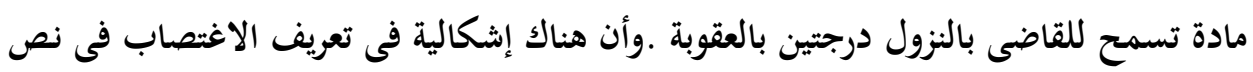


القانون حيث لا يعترف بالاغتصاب الشرجى أو الفمي أو بأداة وتقع تلك الجرائم تحت وصف

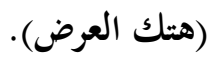

- أشار الخبراء إلى مواجهتهم بعض المشكلات أثناء عملية التدخل العلاجى والتى من أهمها:

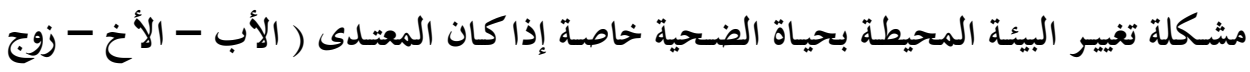

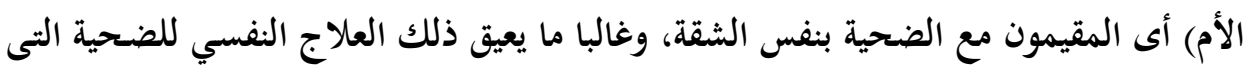

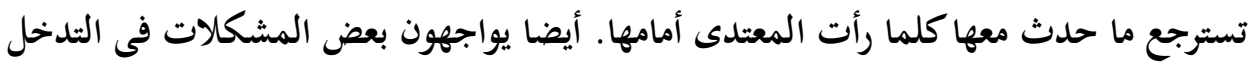
القضائى والتى من بينها: إكتفاء الضحية بما يقدمه المركز من خدمات اتهات تأهيلية وعلاجية وإيوائية،

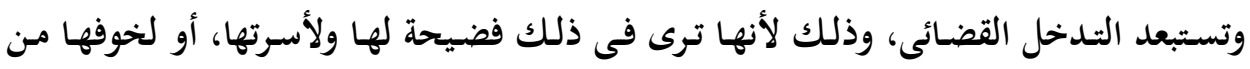

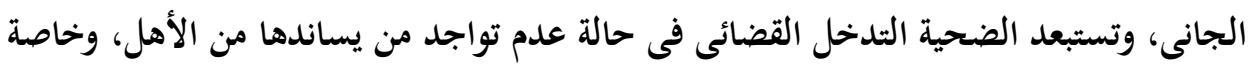

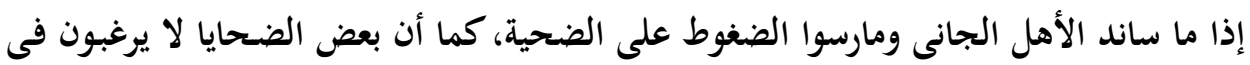

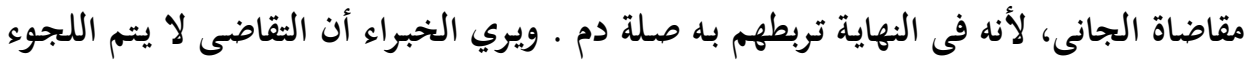

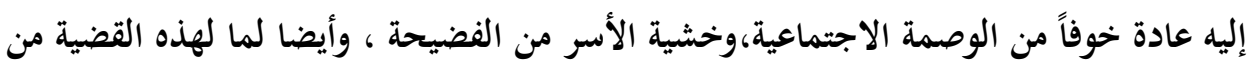

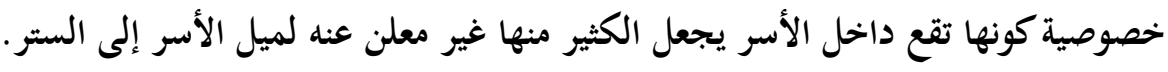

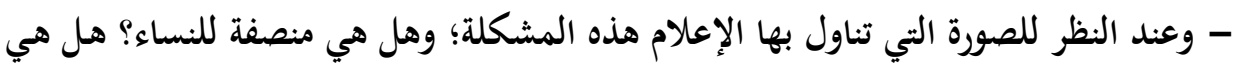

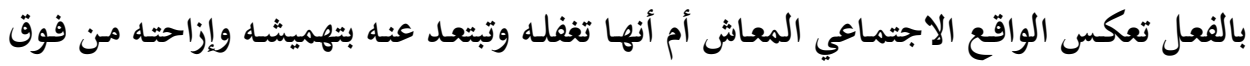

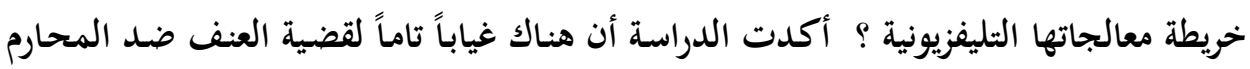

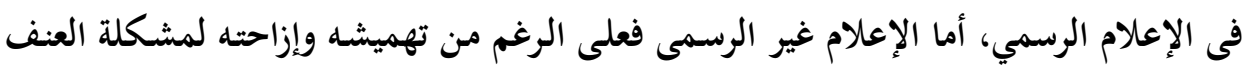

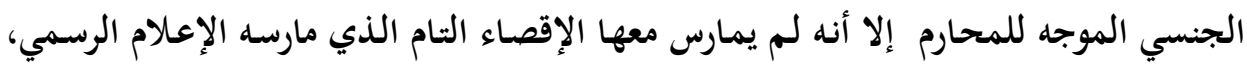

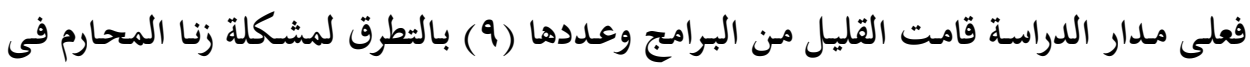

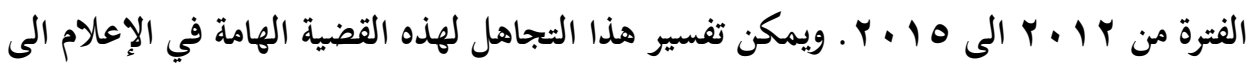

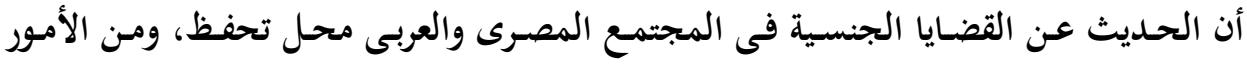

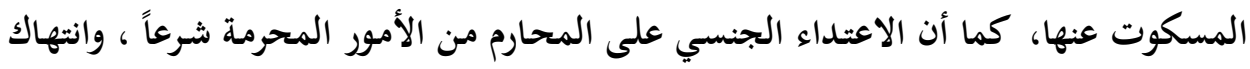

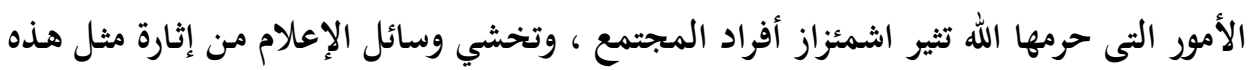

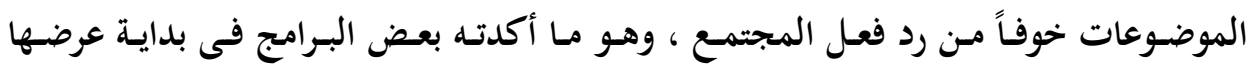

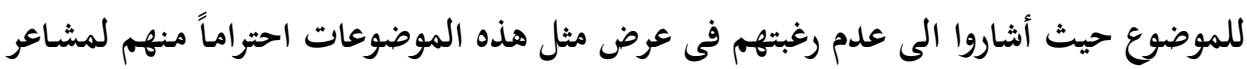


أفراد المجتمع وخوفاً على تأثر العلاقات الاجتماعية بين أفراد الأسرة بسبب إثارة مثل هذه

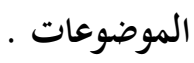

- تناول مشكلة العنف الجنسي ضد المحارم فى عدد قليل من البرامج لا يساهم فى تشكيل

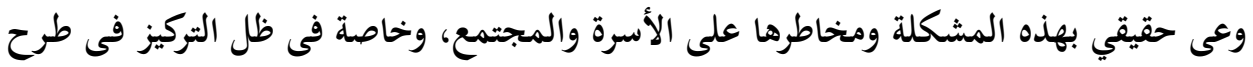

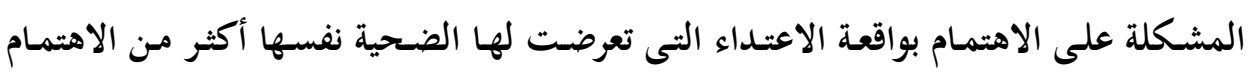
بمعرفة أسبابها والآثار المترتبة عليها. - على الرغم من انخفاض عدد البرامج التى ناقشت مشكلة زنا المحارم فى مجملها إلا أنه من

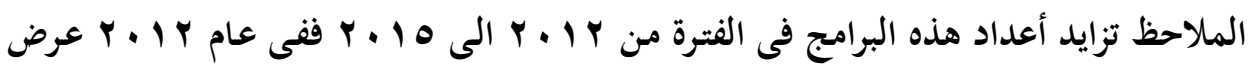

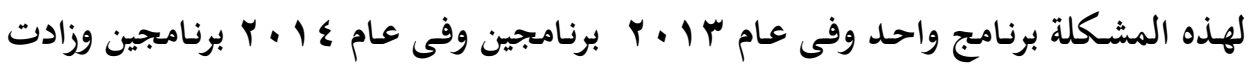

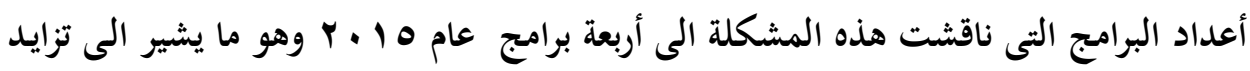

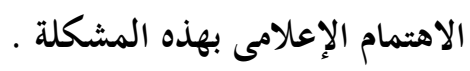

\section{المراجع والهوامش:}

1 - كريم تركي حسـام الدين، اللغـة والثقافـة العربيـة، القاهرة:الهيئة العربيسه العامـه للكتـاب

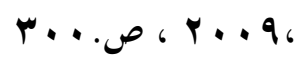

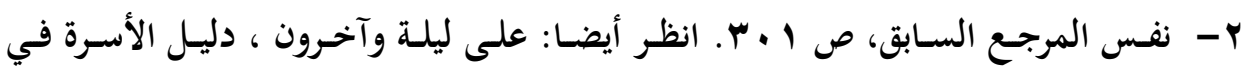

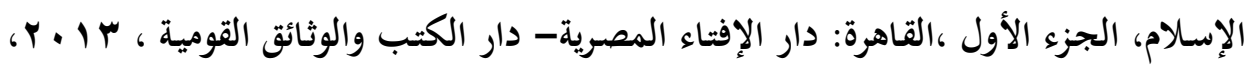

ص. r- على ليلة وآخرون، دليل الأسرة في الإسلام ،الجزء الثاني،القاهرة : دار الإفتاء- دارالكتب

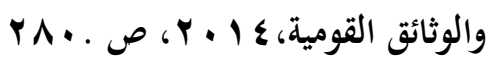

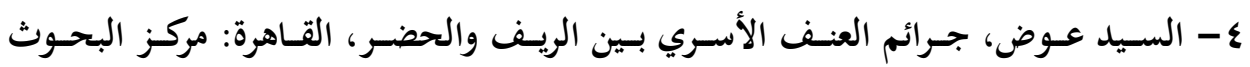

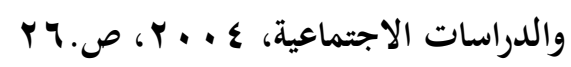
•- حسين أنور ،خلف عبـد السلام، تغير النسق القيمي والجرائم الأسرية: دراسـة تحليلية

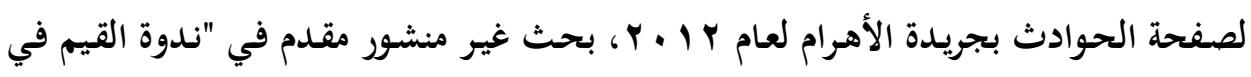

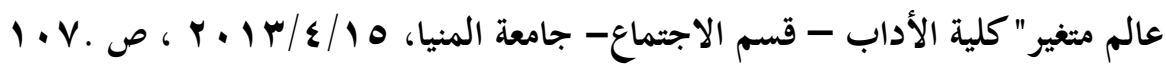




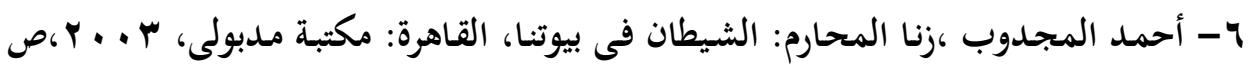

iv.

7- Nisha, The Indian Family: Too Sacrosanct to Touch? Indian

Women's Movement and Civil Society's Responses to Incest Abuse, Agenda: Empowering Women for Gender Equity, No.66, Vol.1, Gender Based Violence Trilogy, Domestic Violence, 2005, p .68

8-Linda Ledray, Victims of Incest, theAmerican Journal and Nursing, Vol.84, No.8 (Aug., 1984), p. 1010.

9- مركز النديم للعلاج والتأهيل النفسي لضحايا العنف، العنف ضد النساء "بحث ميداني"

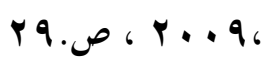

• 1- مركز النديم للعلاج والتأهيل النفسي، النساء والعنف الجنسي: قراءة فى ملفات برنامج

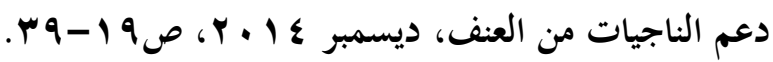

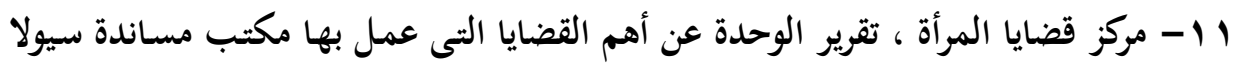

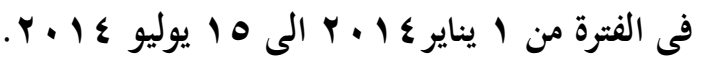

12- Lisanne Brown, Tonya Thurman and others, Sexual Violence in Lesotho, Studies in Family Planning, Vol . 37 , No. 4 (Dec, 2006), p. 269.

13-Jodi Teiteliman, Sexual Abuse of Older Adults: Appropriate Responses for Health and Human Services Providers, Journal of Health and Human Services Administration, Vol. 29, No.2 (Fall., 2006), p.211

ع ا - خالـد منتصـر، الختـان والعنف ضـد المرأة، القـاهرة: الهيئة المصرية العامـة للكتـاب، $.19 r$ r...V

15-Edward Sagarin, Incest: Problems Of Definition and Frequency, The Journal of Sex Research, Vol .13, No.2, (May, 1977) p.129. 16-Ibid, p 129.

17-Nisha, The Indian Family,op.cit, p 72.

18- Edward Sagarin, op.cit, 128.

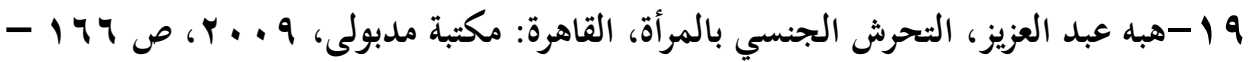




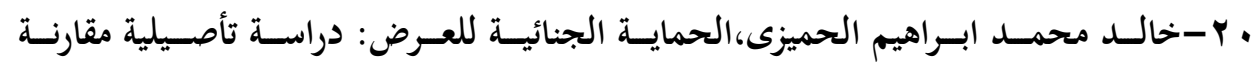

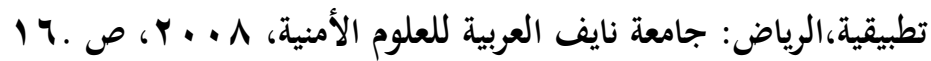

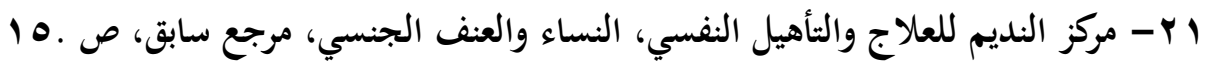

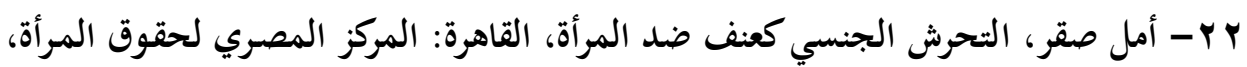
10

23-Clifford T. west, Stephen J. Holoviak, Roberta FLger, Sexual Harassment A mong nursing Professional Evidence and Prescriptions for A dministrators ,Journal of Health an Human Services Administration , Vol 18 , No 2 , Fall 1995, P.166.

ع צw.baheth.info

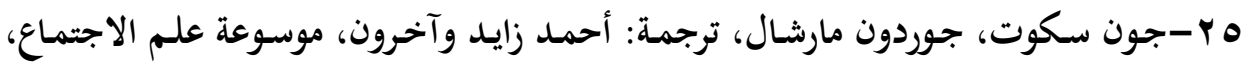

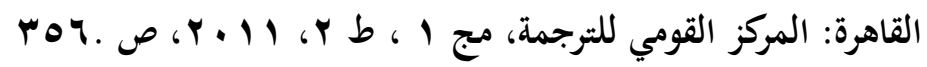

צ אV

^ץ - محمد بن مرزوق العصيمي، مكافحة زنا المحارم: دراسة تأصيلية مقارنة تطبيق، آطروحة

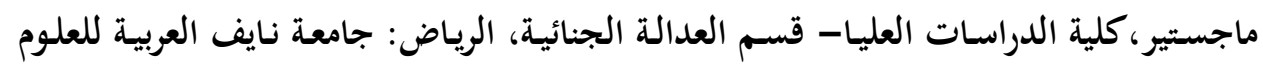

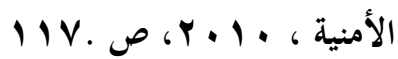

q צ-مركز النديم لتأهيل ضحايا العنف والتعذيب، العنف ضد النساء في مصر، مرجع سابق،

$$
\text { ص. }
$$

• •

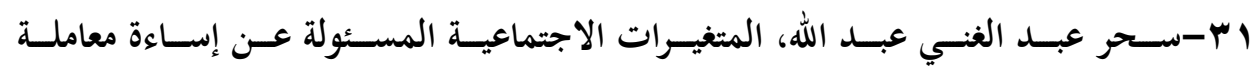

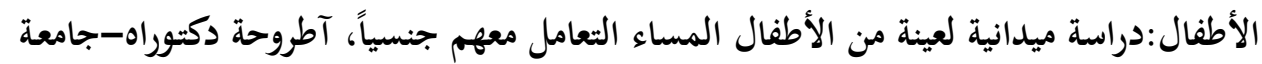

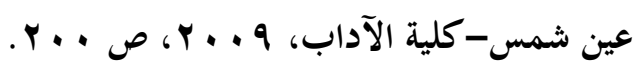

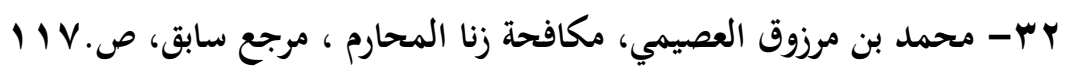

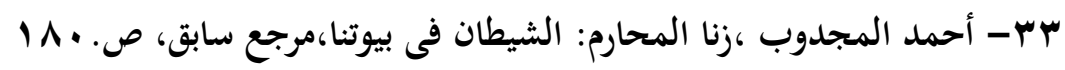


34-Nancy 1, Fisher, Oedipus Wrecked. The Moral Boundaries of Incest, Gender and Society, Vol. 17 - No. 1 , (Feb., 2003), pp 92 - 110. 35-Hyun_Sil Kim, and Hun_Soo Kim, Incestuous Experience among Korean Adolescents: Prevalence, Family Problems, Perceived Family Dynamics, and Psychological Characteristics, Public Healt Nursing, Blackwell Publishing, 2005, Vol. 22, No.1, p 472 - 482

36-Susan I. Ray, Mscn, Rn, Male Survivor's Perspectives Incest, Sexual Abuse Perspectives in Psychiatric Care, Vol.37 - No 2, (April - June., 2001).

37-Donna Lewcowitz, Father - Daughter Incest with A Family

Focus, Proquest: Umi dissertations Publishing(December., 2011)

38-De Rochemont,Jean Francais,A critique of Child Welfare Responses to Susected Cases of Incest,Proquest:Umi Disseritations Publishing,2010.

39-Mary Jayne, Sims, Incest and Child Sexual Abuse in the African American Community: African American Minister's Attitudes and Beliefs, Alliant International Univ, Sanfrancisco Bay, Proquest: Umi Dissertation Publishing, 2002.

40- Anna Meigs and Kathleen Barlow, Beyond the Taboo: imaging incest, American Anthropologist, Vol.104, No.1 (Mar., 2002) p.39.

41-Paul B.Roscoe, Amity and Aggression: Asymbolic Theory of Incest,man;new series, Royal Anthropological Institute of Great Britain and Ireland vol.29,no.1,(mar.,1994),p56.

42-سيغموند فرويد، الطوطم والتابو، ترجمة:بو علي ياسين، سوريا دار الحوار للنشر والتوزيع، 0.0 (191r

43-Anna Meigs and Kathleen Barlow, op.cit, p.39.

44- سيغموند فرويد، ترجمة: جورج طرابيشى، ثلاثة مباحث فى نظرية الجنس ، بيروت-

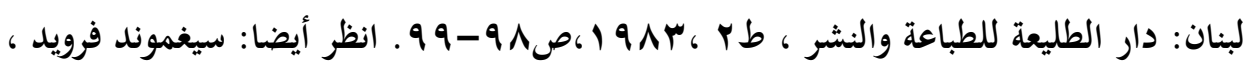

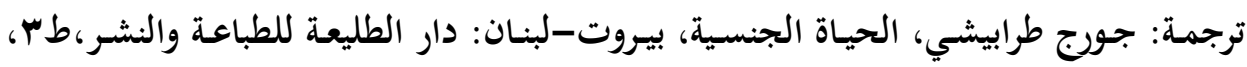
$0 V .-09$ ص ص 1999

45- أحمـد لطفى السيد، المـدخل لدراسـة الظـاهرة الإجراميـة والحقى فى العقـاب، الجزءء

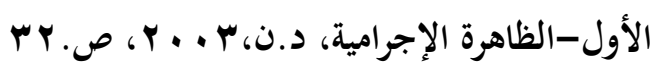


46- أحمد زايد، الأسرة العربية فى عالم متغير، القاهرة: مركز البحوث والدراسات الاجتماعية

$$
9 V .9 \cdot 116
$$

47- سـامية مصطفي الخشـاب، النظريـة الاجتماعيـة ودراسة الأسرة، القـاهرة: الدار الدوليـة

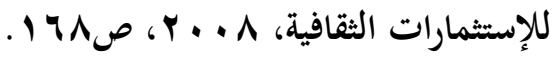

48- Lena Dominell, op.cit, 296.

49-Nancy L. fisher, op. cit, p. 96.

50-Lena Dominell, op.cit, 296.

$$
\text { 51- سيغموند فرويد، الحياة الجنسية، مرجع سابق، صV ه . }
$$

52-Kingsley R. Browne, Sex , Power and Dominance : The

Evolutionary Psychology of Sexual Harassment, Managerial and Decision Economics, Vol .27, No 2/3 , 2006 ,P. 145.

53-Christopher Uggen and Amy Blackstone, Sexual Harassment as Agendered Expression of Power, American Sociological Review, vol. 69, No. 1, ( Feb 2004), P.66.

54-Nancy Muturi and Patricia Donald, Violence against Women and Girls in the Caribbean: An Intervention and Lessons Learned from Jamaica,Caribben Quarterly,Vol.52, No.2/3,(June-Sept.,2006),p.83.

55- لقد حاول الباحثون الحصول على حالات من بعض المؤسسات أو المراكز المعنية بهذا الموضوع ولكن كان الرد بالرفض نظرا لعدم رغبة المؤسسة فى أن تسبب مقابلتنا للضحايا آثاراً

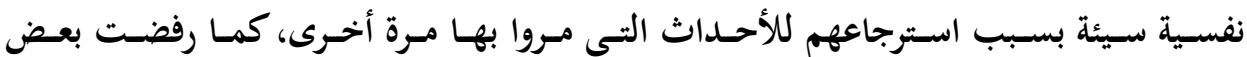

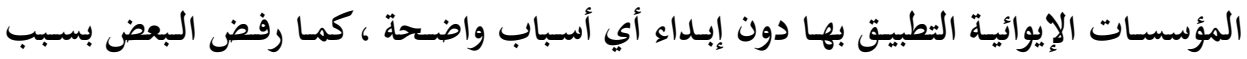
التحفظ على بعض التساؤلات التى جاءت بالدليل .

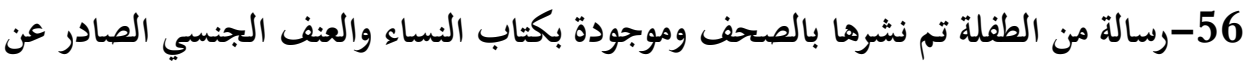

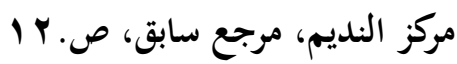

57-Andrew Morrison,Mary Ellsberg and Sarh Bott, Adressing Gender-Based Violence:Acritical Review of Interventions, The Worled Bank Research Observer,Oxford University Press, Vol.22,No.1(Spering.,2007),p.26.

58- Tina Hyder and Johanna Mac Veigh, Gender-Based Violence Against Children in Emergencies: Save the Children UK's Response, Gender and Development, Vol.15, No.1, 2007, p.82. 
59-Ibid, p.27.

60- Gunilla Krantz and Claudia Garcia- Moreno, Violence Against Women, Journal of Epideiology and Community Health,Vol.59, No.10,(oct.,2005), p.818.

61- رباب الحسينى، واقع التنشئة الاجتماعية فى الأسرة المصرية، بحث منشور فى مؤتمر: واقع الأسرة فى المجتمع: تشخيص للمشكلات واستكشاف لسياسات المواجهه، جامعة عين

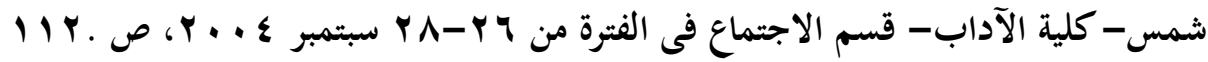

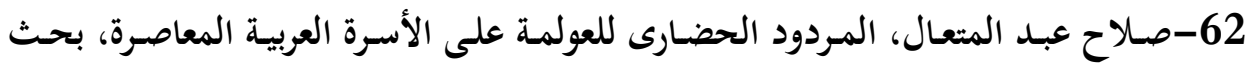
منشسور فى مؤتمر : واقع الأسرة فى المجتمع: تشـخيص للمشكلات واستكشـاف لسياسات

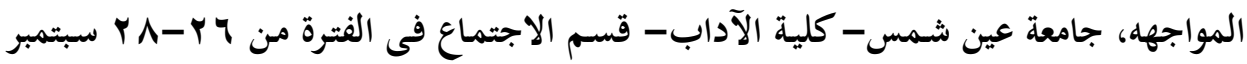
.71 . 7 . . .

63-على ليلة ، تأثير التحولات الاجتماعية والاقتصـادية على بنـاء الأسرة ووظائفها، بحث هـ

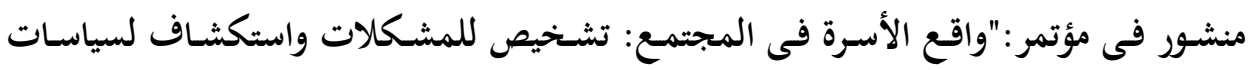

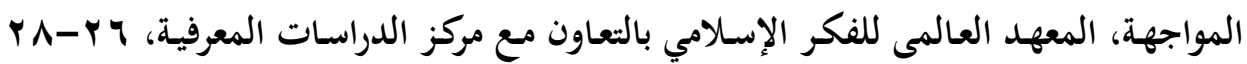

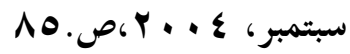
64- على ليلة ، العوامل المسئولة عن الطلاق فى المجتمع المصرى، القاهرة: المركز المصري

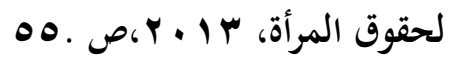
65- محمد الغزالى، قضايا المرأة بين التقاليد الراكدة والوافدة، القاهرة: دار الشروق، ط ج ه، \&0.r...

66- سـحر حساني بربري، أنماط المشـاكل التى يعـانى منها المراهقين والشباب، تحليسل

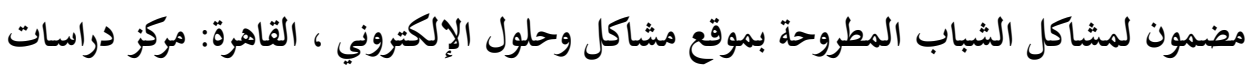

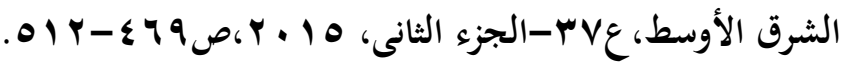
67-Cheryl Buehler, Ambika Krishnakumar and others, , Interparental Conflict Styles and Youth Problem Behaviors: A TwoSample Replication Study, Journal of Marriage and Family, vol. 60, no. 1 (Feb. 1998), p. 109.

, 68- Enid Gruber and Helaine Thau ,Sexually Related Content on Television and Adolescents of Color: Media Theory, Physiological 
Development, and Psychological Impact, The Journal of Negro Education, Vol. 72, No. 4, (Autumn. 2003), p.440.

69-إجلال إسماعيل حلمى، العنف الأسري فى المجتمع العربي: تحليل نقدى، فى مؤتمر:

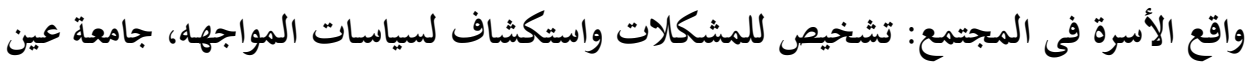

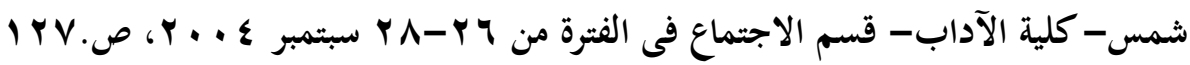

70- سماح صلاح الدين، المجتمع المصرى والعنف ضد المرأة، تونس: مركز المرأة العربية

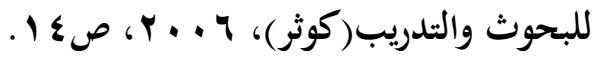

